\title{
Did the Late Paleozoic Ice Age cause reduced evolutionary rates in marine invertebrates? : A test using the crinoid fossil record
}

Daniel C. Segessenman

Follow this and additional works at: https://researchrepository.wvu.edu/etd

\section{Recommended Citation}

Segessenman, Daniel C., "Did the Late Paleozoic Ice Age cause reduced evolutionary rates in marine invertebrates? : A test using the crinoid fossil record" (2016). Graduate Theses, Dissertations, and Problem Reports. 6597.

https://researchrepository.wvu.edu/etd/6597

This Thesis is protected by copyright and/or related rights. It has been brought to you by the The Research Repository @WVU with permission from the rights-holder(s). You are free to use this Thesis in any way that is permitted by the copyright and related rights legislation that applies to your use. For other uses you must obtain permission from the rights-holder(s) directly, unless additional rights are indicated by a Creative Commons license in the record and/ or on the work itself. This Thesis has been accepted for inclusion in WVU Graduate Theses, Dissertations, and Problem Reports collection by an authorized administrator of The Research Repository @ WVU. For more information, please contact researchrepository@mail.wvu.edu. 
Did the Late Paleozoic Ice Age cause reduced evolutionary rates in marine invertebrates? : A test using the crinoid fossil record

\title{
Daniel C. Segessenman
}

\author{
Thesis submitted \\ to the Eberly College of Arts and Sciences \\ at West Virginia University \\ in partial fulfillment of the requirements for the degree of \\ Master of Science in Geology
}

Thomas Kammer, Ph.D., Chair

Tim Carr, Ph.D.

Kathleen Benison, Ph.D.

Department of Geology and Geography

Morgantown, West Virginia

2016

Keywords: Crinoids, Late Paleozoic Ice Age, Evolutionary Rates, Paleontology

Copyright 2016 Daniel Segessenman 


\section{ABSTRACT \\ Did the Late Paleozoic Ice Age cause reduced evolutionary rates in marine invertebrates? : A test using the crinoid fossil record}

\section{Daniel C. Segessenman}

A 2003 paper by Stanley and Powell reported depressed rates of origination and extinction in marine invertebrates during the Late Paleozoic Ice Age (LPIA) as compared to background rates during the Paleozoic. In their paper, trilobites were used as a specific example to support the hypothesis of sluggish evolutionary rates. Thus, can their hypothesis be tested using a different fossil group? Using an updated version of the crinoid database from Sepkoski's 2002 compendium of fossil marine genera, adding data from multiple sources, rates of origination, extinction, and genus duration were calculated at the stage level for the interval from the Early Devonian (419 Ma) to the Late Permian (254 Ma). This $165 \mathrm{~m}$.y. time span includes non-glacial intervals before and after the LPIA, which spanned the Serpukhovian (331 Ma) to Sakmarian (290 Ma), providing background rates for comparison. The data generated on crinoid evolutionary rates during the Middle to Late Paleozoic were analyzed and compared to Stanley and Powell's data to determine if crinoid evolutionary patterns support their findings or suggest an alternative hypothesis.

The results of the analysis performed on the updated crinoid database support Stanley and Powell's hypothesis of depressed evolutionary rates in marine invertebrates during the LPIA. Rates of origination and extinction in all crinoid clades were reduced during the LPIA compared to the intervals examined before and after the LPIA. However, crinoid diversity was higher during the LPIA than the surrounding time intervals as origination rates exceeded extinction rates. This increased diversity does not follow Stanley and Powell's findings of reduced diversity in marine invertebrates during the LPIA. The increased diversity of crinoids through the LPIA indicates that taphonomic bias is not responsible for the depressed evolutionary rates. A lower diversity count would be expected during a glacial interval due to lower sea levels, which would result in reduced outcrop volume.

The difference in diversity trends between crinoids and other marine invertebrates is due to factors specific to the advanced cladids crinoid clade. Unstable, fluctuating environmental conditions during the LPIA created habitats suitable for opportunistic crinoid genera, which reduced both the probability of origination and extinction. Advanced cladids were solely responsible for the high diversity of crinoids during the LPIA because they represented the majority of crinoids. The increased diversity of the advanced cladids is due to their unique adaptation of muscular articulation, which allowed them to thrive in marine settings with increased siliciclastic influx. The advanced cladids responded opportunistically to the environmental change brought on by the Alleghenian orogeny, which caused an increase in siliciclastic dominated marine environments. Despite the advanced cladids' departure from the expected diversity count, the results of analyses performed on the updated crinoid database support Stanley and Powell's original hypothesis of depressed evolutionary rates in marine invertebrates during the LPIA. 


\section{ACKNOWLEDGEMENTS}

West Virginia University has provided me with fantastic opportunities and the ability to work on this Master's thesis is certainly one of them. The reason I wanted to continue my education here at WVU was the attitude and quality of the Geology and Geography department. This project is in no small part thanks to the wonderful faculty, staff, and my peers at the WVU Geology and Geography department. I am very grateful for their support.

I would especially like to thank my advisor and committee Chair of this thesis, Dr. Thomas Kammer. It is thanks to Dr. Kammer that I was able to return to WVU for this project and it is thanks to him that the original question this project is based on was chosen. Dr. Kammer's patience, breadth of knowledge, and experience made working on this project a wonderful part of my academic career. I greatly appreciate all of his assistance and I am grateful to him for helping me on every step of this project, even when some steps took far longer on my part than others. I am quite lucky to have had his guidance.

I would also like to thank Dr. Kathleen Benison and Dr. Tim Carr for taking time out of their busy schedules to be a part of my committee, reading this thesis, and answering any questions I have had along the way. I appreciate them sharing their valuable time very much.

A special thanks goes out to Brittany Hupp, for making the last stages of writing more interesting, providing a second set of eyes, and for motivating me to bring this thesis to a finish.

Finally, I want to include thanks for the support of my parents and my grandmother. Without their encouragement and upbringing I would not have the skills and abilities necessary to pursue my education further, let alone a place to live. My thanks to them for raising me the way they have and supporting my pursuits in the realm of academia. 


\section{TABLE OF CONTENTS}

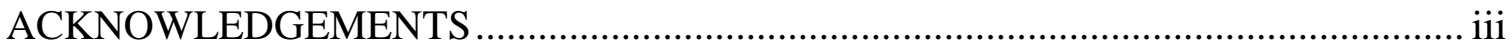

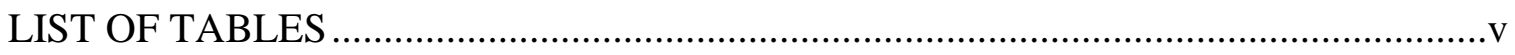

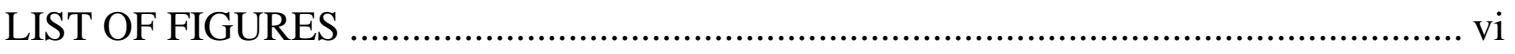

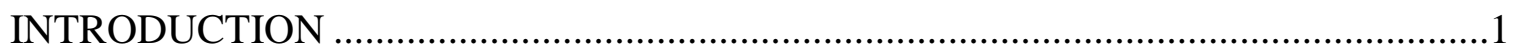

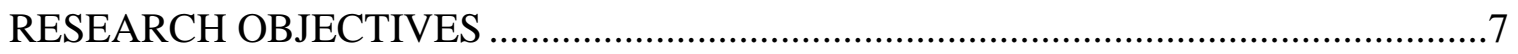

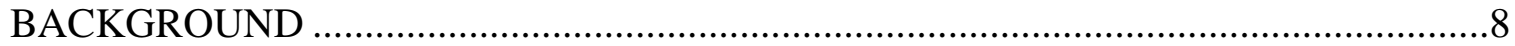

Crinoids .........................................................................................................

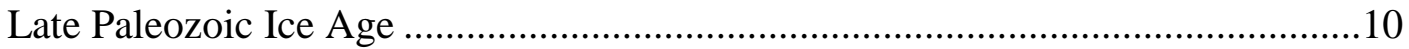

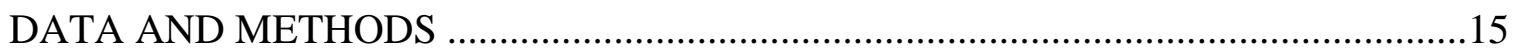

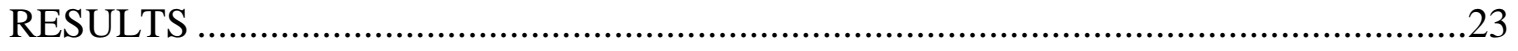

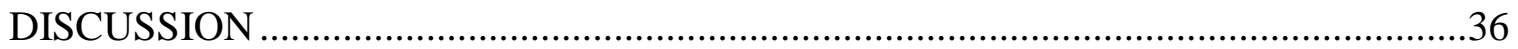

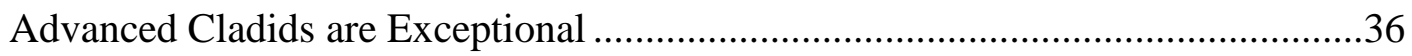

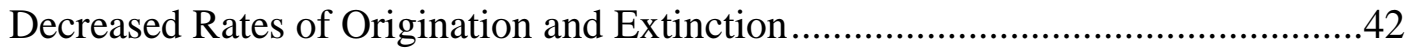

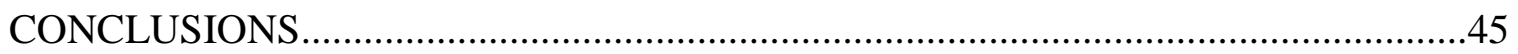

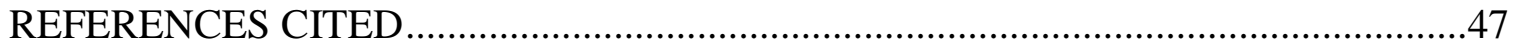

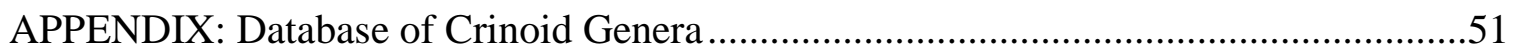

APPENDIX: Converted Data (Absence/Presence) ......................................................66 


\section{LIST OF TABLES}

Table 1. Division of crinoid clades ............................................................ 10

Table 2. Stage names, starting dates, and durations with assigned time bins .........17

Table 3. Excerpt of presence/absence data from diplobathrid crinoids .................21

Table 4. Mean and median genus durations of crinoids during LPIA and

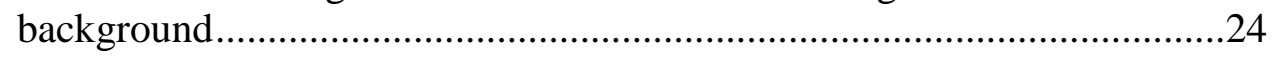

Table 5. Calculated values table for diplobathrids........................................25

Table 6. Calculated values table for monobathrids...........................................26

Table $7 . \quad$ Calculated values table for disparids ...............................................27

Table 8. Calculated values table for primitive cladids......................................28

Table 9. Calculated values table for advanced cladids .....................................29

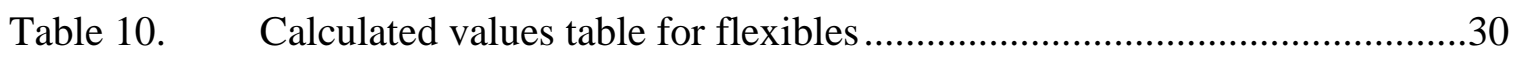

Table 11. Calculated values table for total crinoids................................................

Table 12. Average diversity of crinoids by stage for background and LPIA ............33 


\section{LIST OF FIGURES}

Figure 1. Rates of marine invertebrate origination and extinction and raw diversity counts of marine invertebrates during Ordovician to Permian from Stanley and Powell (2003)

Figure 2. Background vs. LPIA origination and extinction rates of marine invertebrates as \% interval from Stanley and Powell (2003).

Figure 3. Interpreted ocean current patterns through Mid to Late Paleozoic from Shi and Waterhouse (2010)

Figure 4. Mississippian examples of major groups of crinoids from the Paleozoic from Kammer and Ausich (2006)

Figure 5. Blakey Mollweide paleogeographic maps of Miss. and Penn. from Mantanez and Poulsen (2013).

Figure 6. Standing diversity of Paleozoic crinoids: Sepkoski vs. updated crinoid database by stage and by per million years.

Figure 7. Visual representation of stratigraphic range values from Foote and Miller (2007)

Figure 8. List of calculations possible from stratigraphic range values from Foote and Miller (2007)

Figure 9. Mean LPIA PO/PE rates (\% interval) vs. mean background PO/PE (\% interval) rates of crinoids

Figure 10. Net origination and extinction of Paleozoic crinoid clades by stage.........34

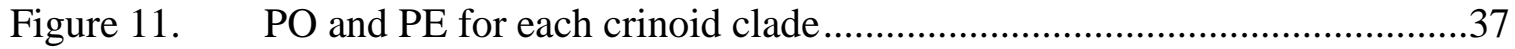

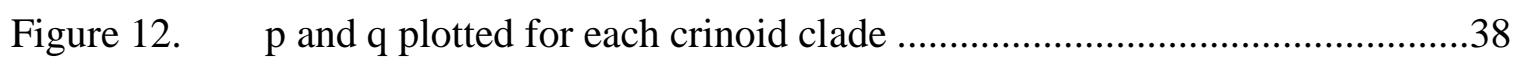

Figure 13. Diversity counts by stage of each crinoid clade ..................................39

Figure 14. Diversity count, PO/PE, and p/q of total Paleozoic crinoids...................40

Figure 15. Diversity count by stage of Paleozoic crinoids as percentages ................41

Figure 16. Latitudinal extent and mean genera durations of Paleozoic brachiopods over time from Powell (2005). 


\section{INTRODUCTION}

Of the many sub-disciplines of paleontology, few are as prevalent as the calculation and analysis of evolutionary rates for fossil organisms. Marine invertebrates are the most abundant organisms in the animal fossil record and are often used to evaluate evolutionary rates during tectonic, ecologic, or climatic events in Earth's history. A major advancement in the study of evolutionary rates for marine invertebrates was the compilation of fossil marine genera by Sepkoski (2002), which included all current data at the time on marine genera from the Cambrian to the Recent. Numerous studies have used Sepkoski's (2002) compendium as a starting point in the analysis of evolutionary rates of various taxonomic groups of marine invertebrates. From these studies, patterns in the macroevolution of marine invertebrates have been identified and studied in greater detail. One such study on large-scale evolutionary patterns in marine invertebrates is by Stanley and Powell (2003).

Stanley and Powell (2003) examined evolutionary rates of marine invertebrates in the Paleozoic, including the period of time known as the Late Paleozoic Ice Age (LPIA). The LPIA is a period of multiple glacial and interglacial stages spanning 331 Ma to 290 Ma (Serpukhovian to Sakmarian) (Shi and Waterhouse, 2010; Gradstein et al., 2012; Montanez and Poulsen, 2013). Stanley and Powell (2003) observed that diversity counts and evolutionary rates of marine invertebrates appeared abnormally low during the LPIA. They hypothesized that during the LPIA, rates of evolutionary turnover decreased as extinction and origination rates for marine invertebrates were depressed (Figure 1A). Reduced diversity counts were reported during the LPIA as well (Figure 1B). 


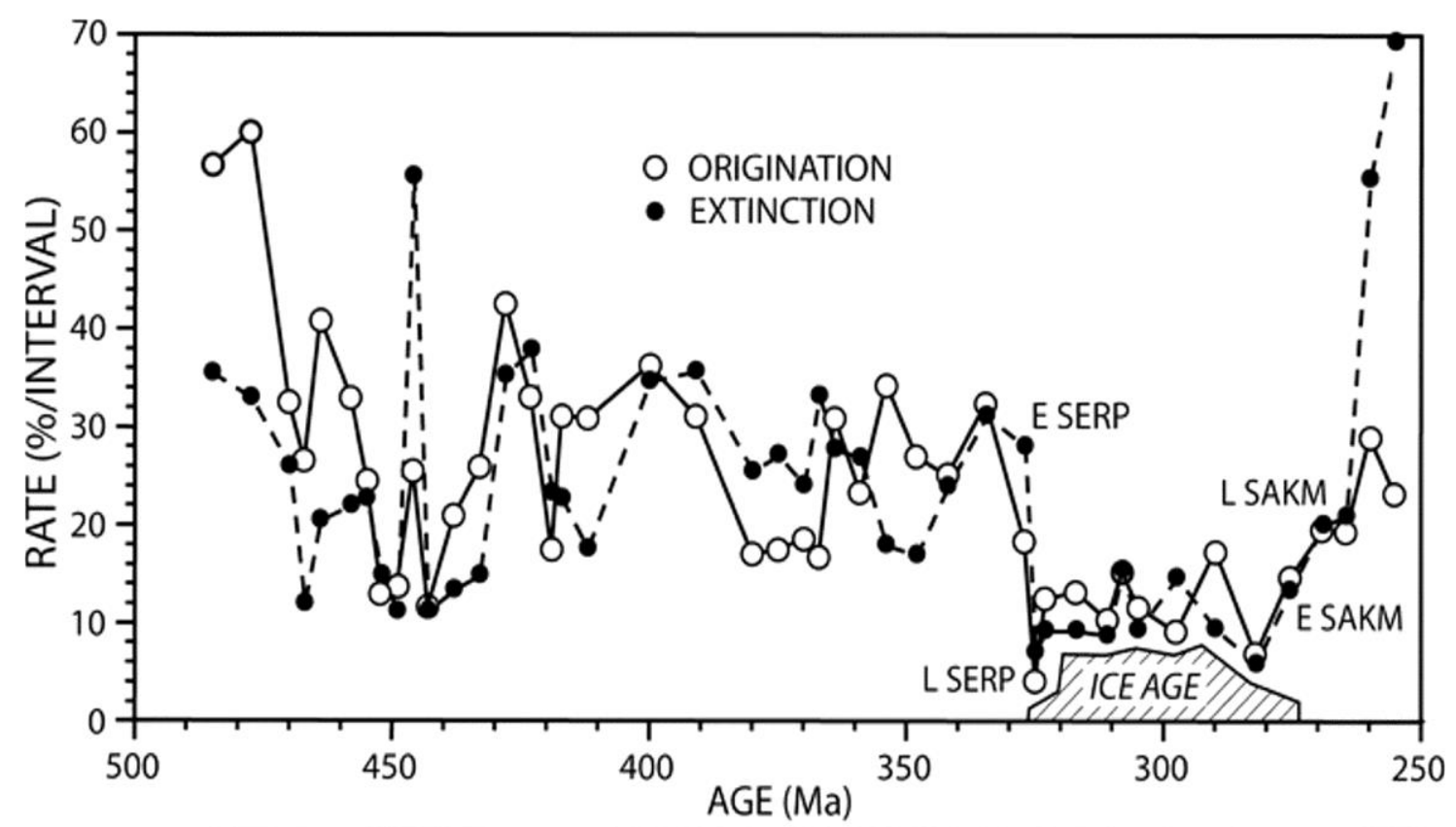

A.
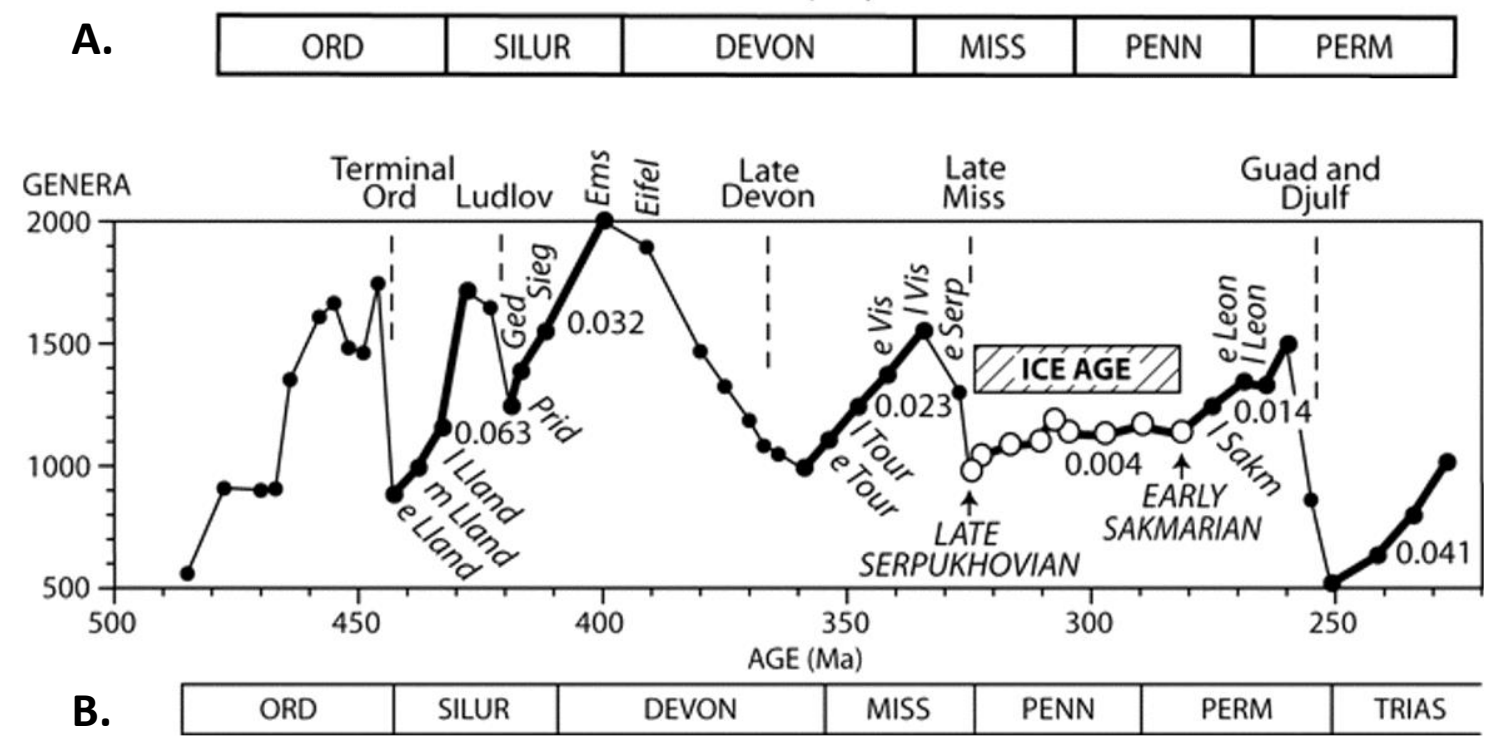

Figure 1 - Phanerozoic diversity and evolutionary rates of fossil marine invertebrates.

(A) Rates of origination and extinction in percentages per interval from the Ordovician to the Permian. (B) Raw diversity counts of marine invertebrate genera from the Ordovician to the Permian by stage. LPIA (Ice Age) marked on these graphs to highlight the evolutionary rates during it. Start and end dates differ from those used in this study because Stanley and Powell used Sepkoski's (2002) stage durations. From Stanley and Powell (2003). 
Stanley and Powell calculated mean background rates of origination and extinction of marine invertebrates compared to the mean origination and extinction rates during the LPIA (Figure 2). All values are below the line of parity, indicating that LPIA origination and extinction rates were lower than background rates of origination and extinction in marine invertebrates. Stanley and Powell used Sepkoski’s (2002) compendium of marine genera to calculate and analyze evolutionary rates of marine invertebrates. However, they state that: "Detailed study of other taxa may reveal that they experienced similar transitions at this time (LPIA) (Stanley and Powell, 2003).” It is beneficial to test their study with a narrow focus; that of a single taxonomic group, rather than the entire marine invertebrate record.

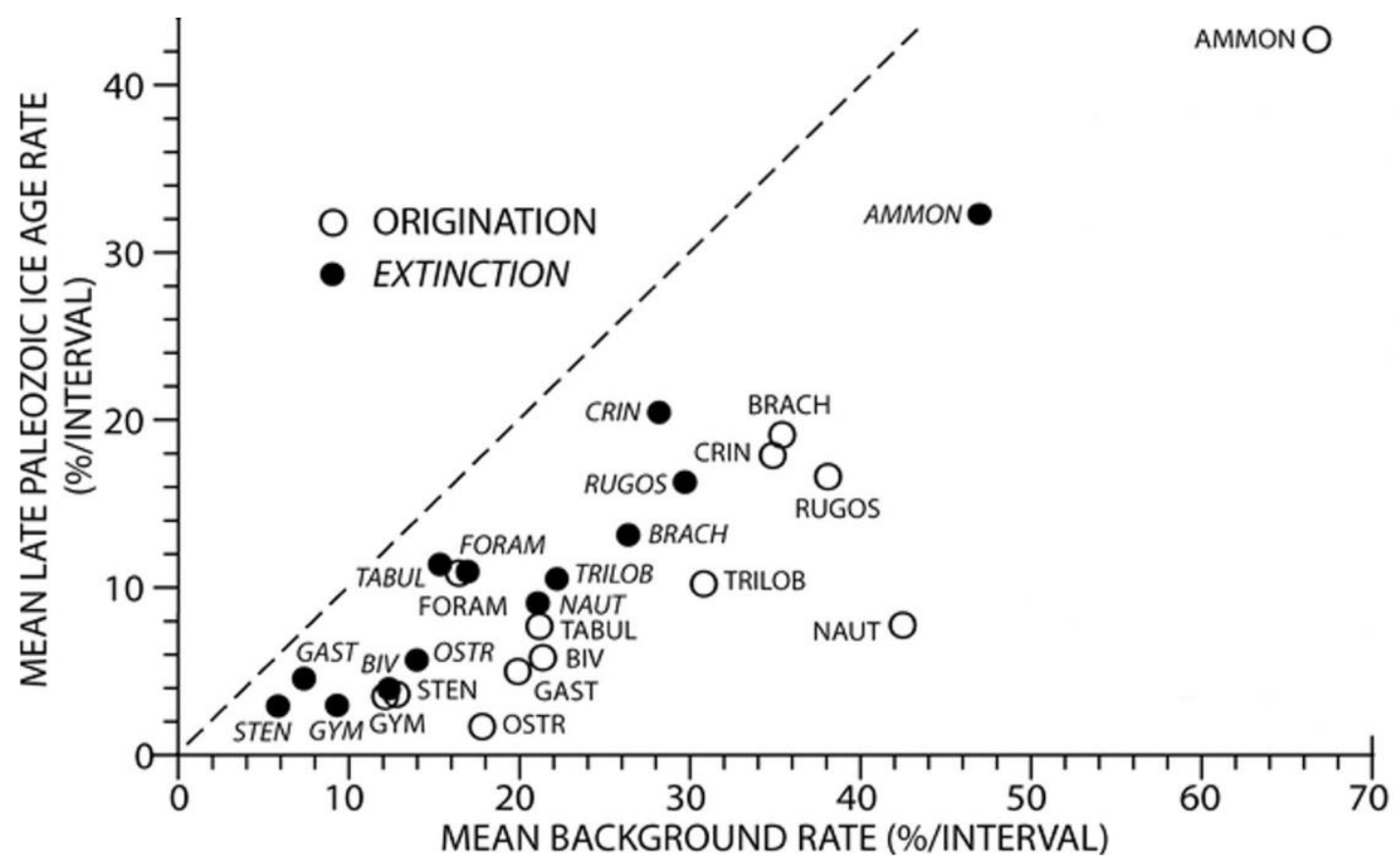

Figure 2 - Origination and extinction rates (\% interval) of marine invertebrates from the LPIA vs. background rates during the Paleozoic. Dashed line represents line of parity (Stanley and Powell, 2003). 
Further examinations of Stanley and Powell's (2003) initial hypothesis have been performed by other workers using several different taxonomic groups of marine invertebrates. An earlier study by Brezinski (1999) was performed on trilobites from the Carboniferous and Permian, which included the LPIA. Powell performed more detailed studies of depressed origination and extinction rates during the LPIA using the fossil record of brachiopods (Powell, 2005; Powell, 2007). Groves and Lee (2008) and Groves and Yue (2009) examined the fossil record of foraminifera during the LPIA to further test Stanley and Powell's (2003) hypothesis. All of the aforementioned studies used a single taxonomic group to examine evolutionary rates during the LPIA and compare them with Stanley and Powell's (2003) hypothesis.

Brezinski’s (1999) study of trilobites and Powell's studies of brachiopods (2005, 2007) support Stanley and Powell's (2003) hypothesis of reduced origination and extinction of marine invertebrates during the LPIA. However, the foraminifera studies by Groves and Lee (2008) and Groves and Yue (2009) indicate increased origination and extinction rates of foraminifera due to unique environmental factors during the LPIA. The global cooling during the LPIA caused higher instability in shallow marine environments due to fluctuating base level. This led to more rapid turnover in communities of foraminifera (fusulinoideans). The rapid turnover of shallow marine foraminifera caused by more unstable environments resulted in faster speciation and therefore, higher evolutionary rates. While the foraminifera behaved in opposition to what was expected, they do not necessarily refute Stanley and Powell's (2003) hypothesis (Groves and Lee, 2008; Groves and Yue, 2009). There are also studies examining localized fossil assemblages to test evolutionary rates during the LPIA. Bonelli and 
Patzkowsky (2011) examined Mississippian fossil assemblages from the Illinois Basin, specifically focusing on evolutionary rates during the LPIA. Bonelli and Patzkowsky (2011) concluded that faunal persistence was the normal response to glacioeustasy during the LPIA and that there was a low degree of turnover during sequences within the LPIA. Stanley and Powell (2003) offered two explanations for the reduced rates of origination and extinction during the LPIA. The first is that environmental conditions during the LPIA limited ecosystem carrying capacities. Due to environmental conditions caused by global cooling, ecosystems were unable to support high diversity communities. They considered this explanation less likely, because it would require competitive exclusion among benthic marine invertebrates, which is not often seen (Stanley and Powell, 2003). The second explanation, which Stanley and Powell (2003) favored, was that LPIA environmental conditions reduced the probabilities of both origination and extinction in marine invertebrates.

LPIA environmental conditions such as the cooling of the oceans would force taxa favoring tropical climates towards the equator and limit their habitable areas. Coldwater currents were directed from the poles to the equator (Figure 3), which would be the driver behind shrinking tropical marine environments (Powell, 2005). Powell (2005) examined a shift in brachiopod median duration and survival style. During the LPIA, brachiopods shifted from more diverse, shorter lived genera that have a narrow latitudinal extent (specialists) to genera that are less diverse, occur in a wider range of environments, and have longer median durations (generalists) (Powell, 2005). The shift from specialists to generalists amongst brachiopod genera would cause depressed rates of origination and extinction, due to genera having a longer median duration. In other words, 

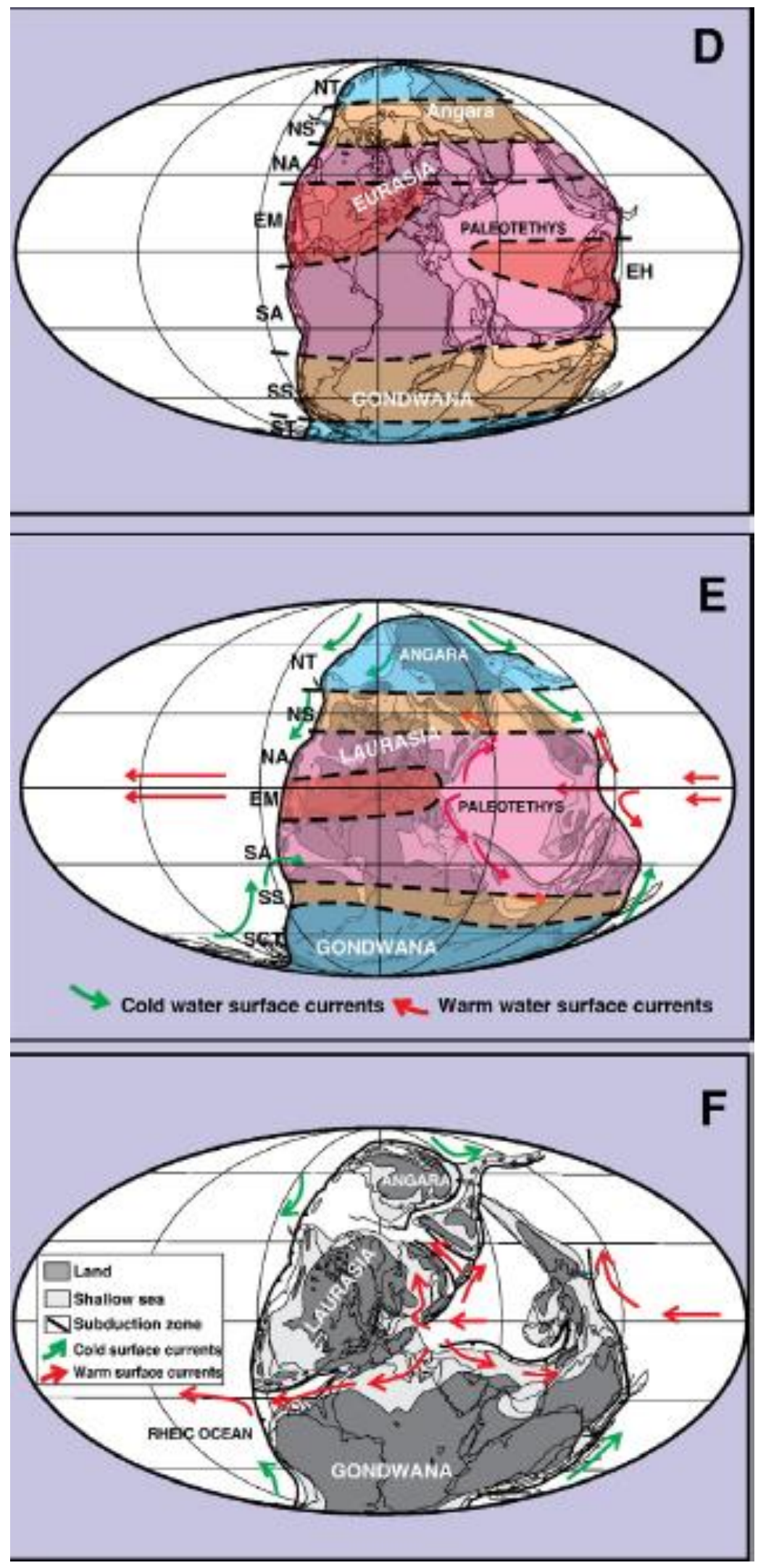

Figure 3 - Paleogeographic reconstructions with modeled ocean currents. Tropical environments compressed during the LPIA as shown for the Pennsylvanian. (D) Late Permian - $255 \mathrm{Ma}$, (E) Pennsylvanian - $306 \mathrm{Ma}$, (F) Mississippian - $356 \mathrm{Ma}$. (Shi and Waterhouse, 2010). 
brachiopod communities dominated by generalist taxa would result in lower probabilities of origination and extinction for those taxa (Powell, 2005). Organisms would be less likely to go extinct, but would also be less likely to develop new forms.

\section{RESEARCH OBJECTIVES}

The focus of this thesis is to calculate, analyze, and discuss evolutionary rates of crinoids during the Middle to Late Paleozoic or Devonian to Permian (419 Ma to 252 Ma), with a focus on the LPIA, Serpukhovian to Sakmarian (331 Ma to $290 \mathrm{Ma}$ ). The null hypothesis proposed in this study is that the evolutionary rates of Paleozoic crinoids were unaffected by the LPIA. The alternative hypothesis is that crinoid evolutionary rates increased or decreased during the LPIA. Diversity counts, rates of origination and extinction, and turnover rates were calculated and analyzed with units at both the stage level and per million years. This thesis study is a further test of Stanley and Powell's (2003) examination of the LPIA's effect on the evolutionary rates of marine invertebrates during the LPIA using an updated database of Paleozoic crinoids. The goal of this thesis is to expand understanding of the LPIA and its effects on the evolutionary rates of marine organisms at the subclass level using crinoids as a test group. A further goal is to offer discussion of the results obtained from analyzing crinoid evolutionary rates during the LPIA and offer possible explanations for what is observed, and potential areas for future study. 


\section{BACKGROUND}

\section{Crinoids}

Crinoids were the most diverse and successful echinoderms of Paleozoic marine invertebrate faunas (Holterhoff, 1997; Sprinkle and Guensberg, 1997). The first major radiation of crinoids (and echinoderms in general) occurred in the Mid-Ordovician at $\sim 470 \mathrm{Ma}$ and until the Permo-Triassic mass extinction at $252 \mathrm{Ma}$ (Payne and Clapham, 2012), crinoids were often the dominant member of Paleozoic marine benthic faunas (Holterhoff, 1997; Guensburg and Sprinkle, 2001). Only one subclass of crinoids (Articulata) is extant today, arising from the survivors of the Permo-Triassic mass extinction. Crinoids never achieved the same levels of diversity during the Mesozoic or Cenozoic as they had in the Paleozoic (Twitchett and Oji, 2005).

Crinoids are marine invertebrates with skeletons composed of interlocking highMg calcified plates (Baumiller, 2008). A typical crinoid has a cup-like calyx that houses most of its organs, a stalk that attaches to a surface with a holdfast to elevate the cup above said surface, and a number of arms that extend from the edges of the calyx. Paleozoic crinoids are considered to have been sessile, often attaching to a solid substrate, whereas extant crinoids such as the comatulids (which lose their stalks early on) are mobile (Baumiller, 2008). Crinoids are passive suspension feeders relying on ocean currents to deliver sustenance. Like all echinoderms, crinoids have a watervascular system with tube feet (which line their arms). Crinoids use their tube feet to capture nutrients from ocean water brought to them on currents. During the Paleozoic, crinoids preferred shallow marine environments, but were also adapted to deeper-water facies (Webster et al., 2005; Ausich and Kammer, 2013). 
There are five subclasses of class Crinoidea: Camerata, Cladida, Disparida, Flexibilia, and Articulata. The only extant subclass of Crinoidea is Articulata. The other four subclasses are Paleozoic members of Crinoidea that went extinct during the PermoTriassic mass extinction (Webster and Jell, 1999; Twitchett and Oji, 2005). Examples from each of the Paleozoic crinoid clades are displayed in Figure 4. Previous thinking was that articulate crinoids did not appear in the fossil record until after the Permian (Simms and Sevastopulo, 1993), but more recent examinations of crinoid lineages include some articulates in the Paleozoic (Twitchett and Oji, 2005). For the purposes of this study, the subclasses Camerata and Cladida have been sub-divided to provide a more detailed view of crinoid evolutionary rates. The camerates are separated into the orders Diplobathrida and Monobathrida. The cladids are separated into the groups "primitive cladids" and "advanced cladids" based on arm morphology (arm pinnules absent or present, respectively, see Figure 4). The separation for cladids is not a Linnaean classification, but pinnulate cladid (advanced cladids) crinoids represent a distinct paleoecologic group (Kammer and Ausich, 2006; Ausich and Kammer, 2013). The divisions of crinoid groups used in calculations for this study are listed in Table 1.

Directly prior to the LPIA, crinoids experienced peak diversity in the Middle Mississippian (Visean) known as the "Age of Crinoids" (Kammer and Ausich, 2006). The drivers implicated in this are reduced predation (Sallan et al., 2011) and the formation of carbonate ramps (Kammer and Ausich, 2006). Crinoids were relatively unaffected by the Late Devonian Hangenberg and Kellwasser extinctions. However, the placoderms, the main fish predators of crinoids during the Late Devonian, went extinct. This temporarily released predation pressure on crinoids, and allowed crinoids to radiate 
strongly in the Mississippian (Sallan et al., 2011). The formation of carbonate ramps is also implicated as a driving force behind the Age of Crinoids. The formation of extensive carbonate ramps during the Mississippian would have resulted in improved open marine circulation unrestricted by barrier reefs expanding shallow marine carbonate facies, essentially increasing the extent of crinoid habitable zones. The formation of extensive carbonate ramps is in large part due to the extinction of stromatoporoid-coral reef systems during the Late Devonian. The start of the LPIA during the Serpukhovian brought the Age of Crinoids to a close (Kammer and Ausich, 2006).

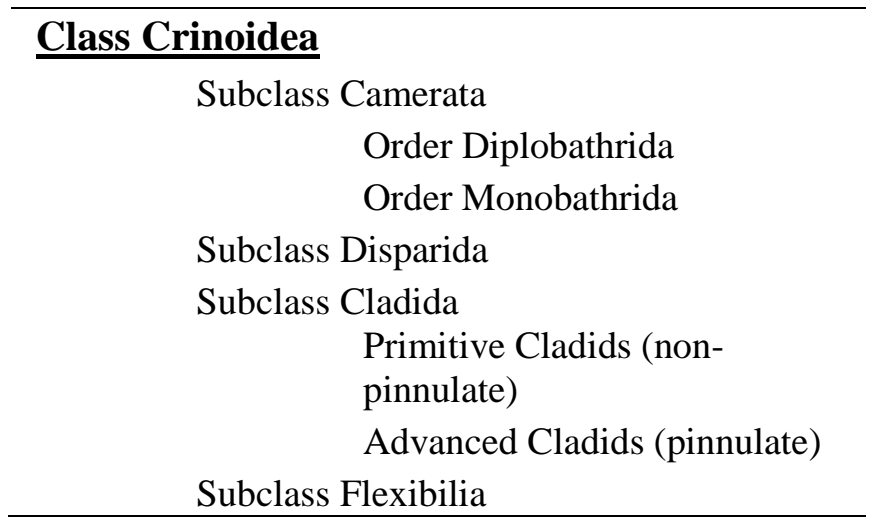

Table 1 - Division of Paleozoic crinoid clades.

\section{Late Paleozoic Ice Age}

The classical view of the LPIA is of a single, uninterrupted glaciation on the scale of tens of millions of years, with some amount of glacial waxing and waning (Fielding et al., 2008). Recent studies and extensive examination of stratigraphic records on multiple continents have caused that view to shift. The most current view of the LPIA is that of a series of 1-8 m.y. glaciation events with interspersed interglacial periods also on a scale 
of 1-8 m.y. over a period of tens of millions of years (Fielding et al., 2008; Shi and Waterhouse, 2010; Montanez and Poulsen, 2013). Glacioeustatic sea level fluctuations during the LPIA have a recognized minimum of $10 \mathrm{~m}$, a maximum of $120 \mathrm{~m}$, directly related to ice volume of Gondwanan glaciation (Rygel et al., 2008).
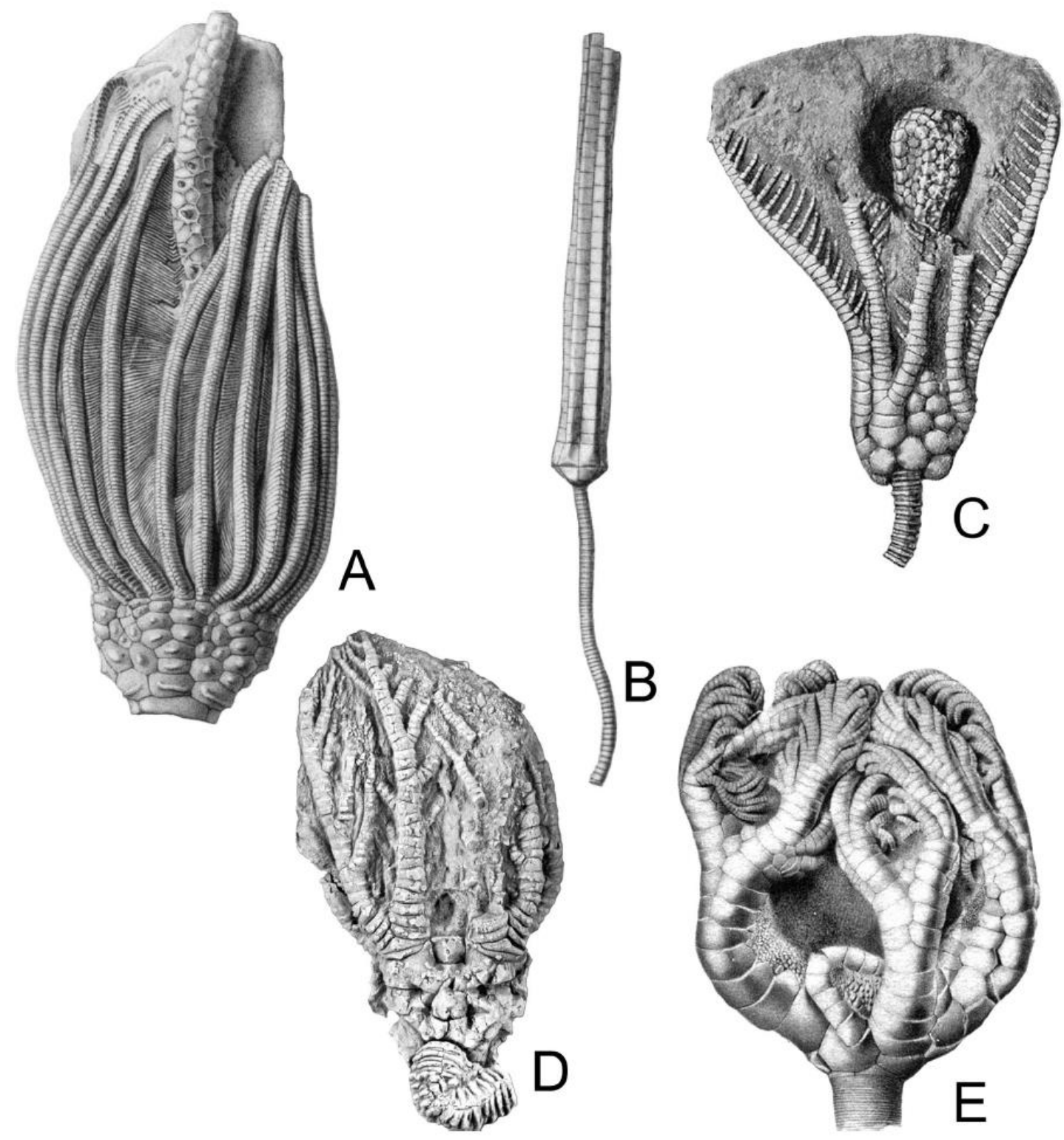

Figure 4 - Mississippian (Visean) examples of five major groups of Paleozoic crinoids. (A) Camerate, note the dense, fine pinnules (B) Disparid, (C) Advanced Cladid, note the large, coarse pinnules (D) Primitive Cladid, note the ramulate arms, (E) Flexible, note the ramulate arms. From Kammer and Ausich (2006). 
There is some variation in the literature as to when the LPIA initiated and when it terminated. Montanez and Poulsen (2013) place the LPIA at $\sim 335$ to 260 Mya. Shi and Waterhouse (2010) place the LPIA at 350 to 280 Mya. Fielding et al. (2008) separate the LPIA into three glaciations, each spanning 10-25 m.y. and ranging from the latest Devonian to Middle Permian. For this study the duration of the LPIA was placed between the shortest and longest estimates. For calculations of evolutionary rates of crinoids, the LPIA is a time period that spans the upper Mississippian (Serpukhovian) to the lower Permian (Sakmarian), or approximately 331 Ma to 290 Ma (Fielding et al., 2008; Shi and Waterhouse, 2010; Montanez and Poulsen, 2013). These are the same stage boundaries recognized by Stanley and Powell (2003).

The most recent climatic event comparable (in magnitude) to the LPIA is the Last Glacial Maximum (LGM) during the Cenozoic at 20,000 k.y.a. (Hyde et al., 1999; Sur et al., 2010). Climatic drivers such as atmospheric $\mathrm{CO}_{2}$, orbital forcing, and atmospheric dust are major factors driving glaciation during the LPIA that are considered analogous to LGM glaciation drivers (Sur et al., 2010; Montanez and Poulsen, 2013). Milankovitchband glacial-interglacial rhythmites from LPIA age strata used as evidence for glacial cyclicity are comparable to similar banding from LGM age strata (Maynard and Leeder, 1992; Sur et al., 2010; Franco et al., 2012). The Milankovitch style banding present in LPIA strata indicates that orbital forcing may have been a strong factor contributing to the cyclic nature of LPIA glaciations (Franco et al., 2012).

Unlike the Cenozoic LGM glaciation, tectonics have been implicated as the main driver behind the LPIA's initiation. The initiation of the LPIA is thought to have resulted from the closing of multiple seaways during Pangaea's assembly, chiefly the Rheic 
Gateway, which would have increased the area of continental climate systems at high southern latitudes (Montanez and Poulsen, 2013). The majority of glaciation for the LPIA was located on the continent of Gondwana in the southern hemisphere (Figure 5). Whether or not there was extensive glaciation in the Northern Hemisphere during the LPIA is a matter of debate (Rygel et al. 2008; Shi and Waterhouse, 2010).

In general, it is agreed upon that the first glaciations preceding the LPIA were minor alpine glaciers during the latest Devonian and earliest Mississippian (Fielding et al., 2008; Shi and Waterhouse, 2010). However, regression-driven incised valleys ( 60 m of incision) in tropical strata (Kammer and Matchen, 2008) together with a positive shift in $\delta^{18} \mathrm{O}$ of marine fossil carbonates (Montanez and Poulsen, 2013), suggest more extensive glaciations than isolated alpine glaciers during glaciations directly preceding the LPIA. Peak glaciation during the LPIA occurred twice: the latest Mississippian and the Middle Pennsylvanian (Rygel et al., 2008; Shi and Waterhouse, 2010; Montanez and Poulsen, 2013). During the Mid to Late Pennsylvanian, there was an interglacial period ( 9 m.y.) indicated by eustatic rise (Fielding et al., 2008; Montanez and Poulsen, 2013). The last pulse of glaciation occurs in the Early Permian with another eustatic fall (Fielding et al., 2008; Shi and Waterhouse, 2010; Montanez and Poulsen, 2013). The end of the LPIA is generally inferred by deglaciation during the mid-Sakmarian (Montanez and Poulsen, 2013), though there is evidence for continued glaciation in eastern Gondwana until 260 Mya (Fielding et al., 2008; Waterhouse and Shi, 2010). 
Mississippian: 340 Mya
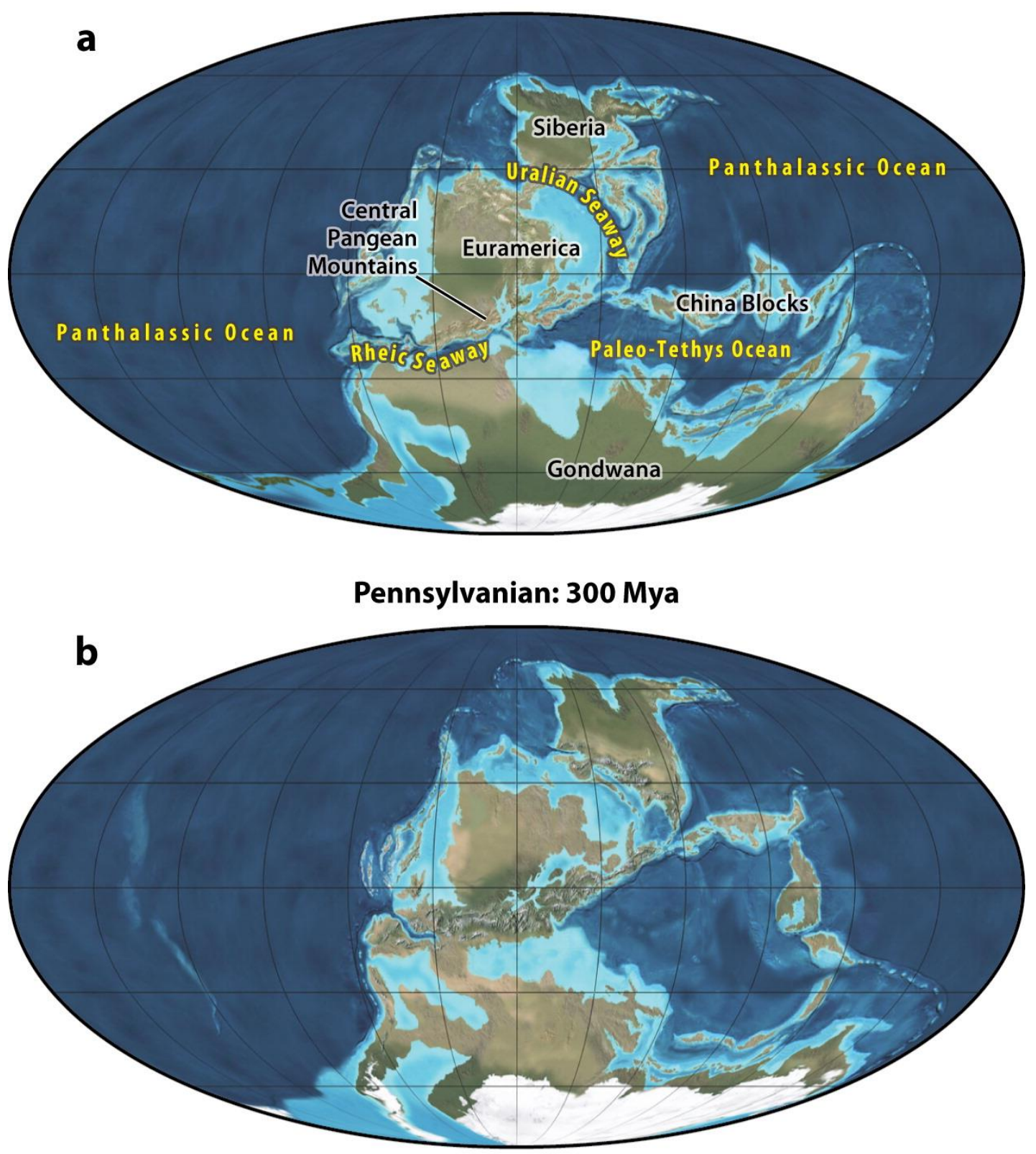

Figure 5 - Mollweide Paleogeographic maps of (a) Late Mississippian icehouse and (b) Early Pennsylvanian peak icehouse, courtesy of R. Blakey, http://www2.nau.erb/rcb7/ (Montanez and Poulsen, 2013). 


\section{DATA AND METHODS}

Analyses of Paleozoic crinoid evolutionary rates were performed on a database of crinoid genera, which has been updated from Sepkoski's (2002) compendium of marine genera. Sepkoski's data on crinoids were combined and updated with data from Kammer and Ausich (2006), Rhenberg and Kammer (2013), Rhenbherg et al. (2015), and Webster (2015). The updated database contains 735 unique crinoid genera along with First Appearance Dates (FADs) and Last Appearance Dates (LADs) of each entry (Appendix). There were 143 crinoid genera added, and 112 FADs/LADs revised in the process of updating Kammer and Ausich's (2006) Devonian-Permian crinoid database. The time range of the database spans from the Lochkovian (419.2 Ma) to the Changhsingian (252.2 Ma). The time scale from Gradstein et al. (2012) used for the database is displayed in Table 2. Sepkoski's (2002) Paleozoic crinoid data was compared with the updated data in terms of standing diversity by stage and by per million years (Figure 6).

Each new genus entry and range revision in the updated database was carefully considered. Any entries without clear locality information, or any genera with questionable FADs or LADs that could not be resolved through further checking, were not included in the updated database. The time range of the study was expanded to the Devonian through Late Permian so that background evolutionary rates of crinoids could be compared to evolutionary rates of crinoids during the LPIA. Ordovician and Silurian stage data were included so that crinoid genera that originated before the Devonian could be included in calculations of evolutionary rates. Stage names were converted to time bins, 1-31, starting with the Tremadocian as time bin 1 and ending with the Changhsingian as time bin 31 (Table 2). The Ordovician, Silurian, and latest Permian 
(Changhsingian, time bin 31) were excluded from the time interval studied. The Ordovician and Silurian were excluded (except for those genera that originate in the Ordovician/Silurian and continue into the Devonian) because this study builds on the database of Kammer and Ausich (2006), which only included Devonian through Pennsylvanian occurrences. Permian occurrences were updated and added for this study. The Latest Permian stage, the Changhsingian, was excluded due to a lack of reported crinoid data.

The majority of new genera entered into the database were Permian in age, and many of the new entries are from localities on the island of Timor (Indonesia), particularly the Basleo fauna. There has been some debate in the literature regarding the age of the rocks containing the Timor specimens (Webster, 1998; Charlton et al., 2002; Sepkoski, 2002). An Artinskian age was chosen for this study because many of the Timor species are also recorded in the Artinskian of the Ural Mountains of Russia and Artinskian units from Australia (Webster, 2015). A recent study revising ranges of the crinoid Graphiocrinus summarizes evidence indicating that the Basleo fauna of West Timor (where many of the Permian crinoid specimens in question come from) is likely Artinskian to Kungurian in age (Webster and Donovan, 2015).

After the database was updated, the ranges based on the FADs and LADs of each genus were converted to presence/absence data. A small example of the presence/absence data format has been included as Table 3. Range data were compiled using the rangethrough method from FAD to LAD. Range data were resolved only to the stage level. Once the presence/absence data were prepared, stratigraphic range variables were calculated for each time interval (Time Bins 11-30) included in this study. Four main 


\begin{tabular}{|c|c|c|c|c|c|c|c|c|c|}
\hline & & & & & & & & & \\
\hline & & Updated & Bins & (Ma) & Duration (Ma) & Sepkoski, 2002 & Bins & (Ma) & Duration (Ma) \\
\hline & & Changhsingian & 31 & 254.2 & 2.0 & Isningian & 7 & 2,0 & 01 \\
\hline & & Wuchiapingian & 30 & 259.8 & 5.6 & Lupingidn & 21 & 200.4 & 9.4 \\
\hline & $\frac{\sqrt{\frac{\pi}{2}}}{\frac{0}{2}}$ & Capitanian & 29 & 265.1 & 5.3 & $\begin{array}{c}\text { Guadalupian- } \\
\text { upper }\end{array}$ & & & \\
\hline$\cdot \frac{\bar{\sigma}}{\bar{E}}$ & $\begin{array}{l}\frac{\pi}{i} \\
\frac{\pi}{\pi} \\
0 \\
0\end{array}$ & $\begin{array}{c}\text { Wordian \& } \\
\text { Roadian }\end{array}$ & 28 & 272.3 & 7.2 & $\begin{array}{l}\text { Guadalupian- } \\
\text { lower }\end{array}$ & $\angle 6$ & $2 / 0.6$ & 10.2 \\
\hline & & Kungurian & 27 & 279.3 & 7.0 & Leonardian & 25 & 284.4 & 13.8 \\
\hline & $\div \frac{5}{\pi}$ & Artinskian & 26 & 290.1 & 10.8 & & & & \\
\hline & $\sum^{\frac{4}{0}}$ & Sakmarian & 25 & 295.5 & 5.4 & Wolfcampian & 24 & 299 & 14.6 \\
\hline & & Asselian & 24 & 298.9 & 3.4 & & & & \\
\hline$\cong$ & $\leq \frac{\square}{5}$ & $\begin{array}{l}\text { Gzhelian \& } \\
\text { Kasimovian }\end{array}$ & 23 & 307.0 & 8.1 & Stephanian & 23 & 306.5 & 7.5 \\
\hline$\frac{0}{2}$ & $\bar{\Xi} \frac{\pi}{2}$ & Moscovian & 22 & 315.2 & 8.2 & Moscovian & 22 & 311.7 & 5.2 \\
\hline : & & Bashkirian & 21 & 323.2 & 8.0 & Bashkirian & 21 & 318.1 & 6.4 \\
\hline 은 & $\dot{n}=$ & Serpukhovian & 20 & 330.9 & 7.7 & Serpukhovian & 20 & 326.4 & 8.3 \\
\hline & 昜 & Visean & 19 & 346.7 & 15.8 & Visean & 19 & 345.3 & 18.9 \\
\hline & & Tournaisian & 18 & 358.9 & 12.2 & Tournaisian & 18 & 359.2 & 13.9 \\
\hline & & Famennian & 17 & 372.2 & 13.3 & Famenian & 17 & 374.5 & 15.3 \\
\hline & & Frasnian & 16 & 382.7 & 10.5 & Frasnian & 16 & 385.3 & 10.8 \\
\hline . & & Givetian & 15 & 387.7 & 5.0 & Givetian & 15 & 391.8 & 6.5 \\
\hline ริ & & Eifelian & 14 & 393.3 & 5.6 & Eifelian & 14 & 397.5 & 5.7 \\
\hline ฮั่ & & Emsian & 13 & 407.6 & 14.3 & Emsian & 13 & 407 & 9.5 \\
\hline & & Pragian & 12 & 410.8 & 3.2 & Siegenian & 12 & 411.2 & 4.2 \\
\hline & & Lochkovian & 11 & 419.2 & 8.4 & Gedinian & 11 & 416 & 4.8 \\
\hline & & Pridolian & 10 & 423.0 & 3.8 & Pridolian & 10 & 418.7 & 2.7 \\
\hline.$\overline{\frac{\pi}{2}}$ & & Ludlowvian & 9 & 427.4 & 4.4 & Ludlowvian & 9 & 422.9 & 4.2 \\
\hline$\frac{3}{5}$ & & Wenlockian & 8 & 433.4 & 6.0 & Wenlockian & 8 & 428.2 & 5.3 \\
\hline & & Llandovery & 7 & 443.8 & 10.4 & Llandovery & 7 & 443.7 & 15.5 \\
\hline & & Ashgillian & 6 & 451.1 & 7.3 & Ashgillian & 6 & 449 & 5.3 \\
\hline & & Caradocian & 5 & 460.9 & 9.8 & Caradocian & 5 & 460.9 & 11.9 \\
\hline$\frac{\bar{v}}{3}$ & & Llandelian & 4 & 466.0 & 5.1 & Llandelian & 4 & 464.5 & 3.6 \\
\hline 웅 & & Llanvirnian & 3 & 471.0 & 5.0 & Llanvirnian & 3 & 468.1 & 3.6 \\
\hline ఫั & & Arengian & 2 & 478.6 & 7.6 & Arengian & 2 & 478.6 & 10.5 \\
\hline & & Tremadocian & 1 & 485.4 & 6.8 & Tremadocian & 1 & 488.3 & 9.7 \\
\hline
\end{tabular}

Table $\mathbf{2}$ - Time bins assigned to stages, starting dates, and duration of each stage updated for use in analyses on the left (Gradstein et al., 2012). Stage names, time bins, starting dates, and duration of each stage used by Sepkoski (2002) on right. 


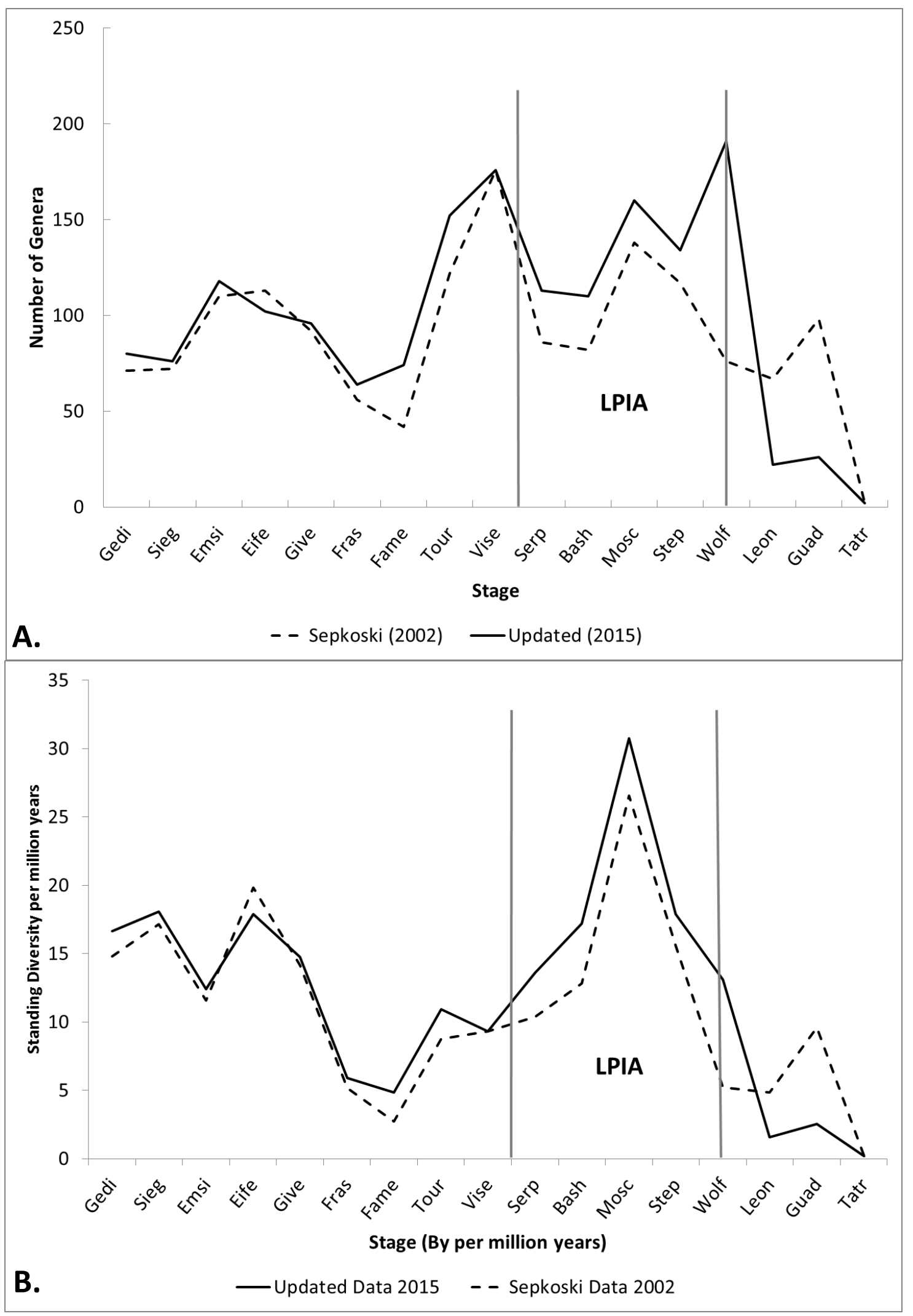

Figure 6 - Standing diversity of crinoids from Sepkoski's (2002) compendium of marine genera compared to the updated crinoid database (Appendix) standing diversity by stage. $(\mathrm{A})$ is the comparison graph using data by stage. (B) comparison graph using data per million years. 
variables described by Foote and Miller (2007) and Alroy (2014) were the basis for all subsequent calculations of evolutionary rates for crinoids during the LPIA (Figures 7 and 8): 1) $\mathrm{NbL}$, a variable representing taxa that have their FAD before an interval of interest and their LAD within that same interval; 2) NFt, a variable representing taxa that have their FAD within an interval of interest and have their LAD after that same interval; NFL, a variable representing taxa that have a FAD and a LAD within the same interval; and 4) Nbt, a variable representing taxa that 'range-through' or taxa that have their FAD before the interval of interest and their LAD after the same interval. These four variables are graphically defined in Figure 7. All values that can be calculated from them are shown in Figure 8 (Foote and Miller, 2007).

Once the stratigraphic range values were checked for accuracy, several calculations were performed for each crinoid clade to examine their evolutionary trends in relation to the LPIA. Mean and median crinoid genus durations are listed in Table 4 whereas all other values calculated for each crinoid clade are listed in Tables 5 through 11. The most significant of the values calculated are the following: 1) PO/PE, the proportion of origination/extinction for genera within a single interval that includes singletons (NFL, genera found only in one stage); 2) p/q, the per-capita origination/extinction for genera within a single interval not including singletons; 3) mean genus durations for total crinoids and each crinoid clade during the LPIA and outside the LPIA (Baumiller, 1993; Powell, 2007; Foote and Miller, 2007; Alroy, 2014). It is important to look at the rates of origination/extinction with and without singletons, or single interval taxa, included. Rates calculated with singletons from a well-sampled interval, such as the Mississippian for crinoids, are likely to represent real trends. The 
singleton taxa from the Mississippian are well constrained and represent genera that have short durations. Rates calculated with singletons from a less sampled interval, such as the Permian for crinoids, may be more suspect. The singleton taxa in the Permian are more likely to represent an artifact in the evolutionary rates due to an inherent taphonomic bias. Evolutionary rates including and excluding singletons were calculated, to better understand evolutionary patterns of crinoids during the LPIA.

For evolutionary rates calculated as background rates, certain time ranges were excluded to make sure the rates did not include any data that may bias the values. The LPIA interval (time bins 20-25) was excluded from the calculations of background rates so its effect was not part of the background evolutionary values. The intervals including the Permian mass extinction were also excluded (Time bins 29-31) so as to not capture the effects of the mass extinction event in the background evolutionary rates. The latest Permian interval also contained little to no data, which likely represents at least a partial taphonomic bias, from lack of Late Permian marine rocks outside of Asia (Gradstein et al., 2012), in addition to the effects of the Permian mass extinction. Data within individual clades was also considered, and certain time frames are excluded for individual clades. For example, the fossil record of diplobathrids ends before the close of the LPIA (Serpukhovian) therefore they were not included in calculations involving the LPIA. Advanced cladids do not originate/have sufficient data until the Emsian, so the proceeding stages of the Lochkovian and Pragian are not included in background rate calculations for advanced cladids to avoid artifacts.

Background evolutionary rates for all clades (excluding diplobathrids and the advanced cladids) were calculated from the Lochkovian to Visean (Time bins 11-19) and 


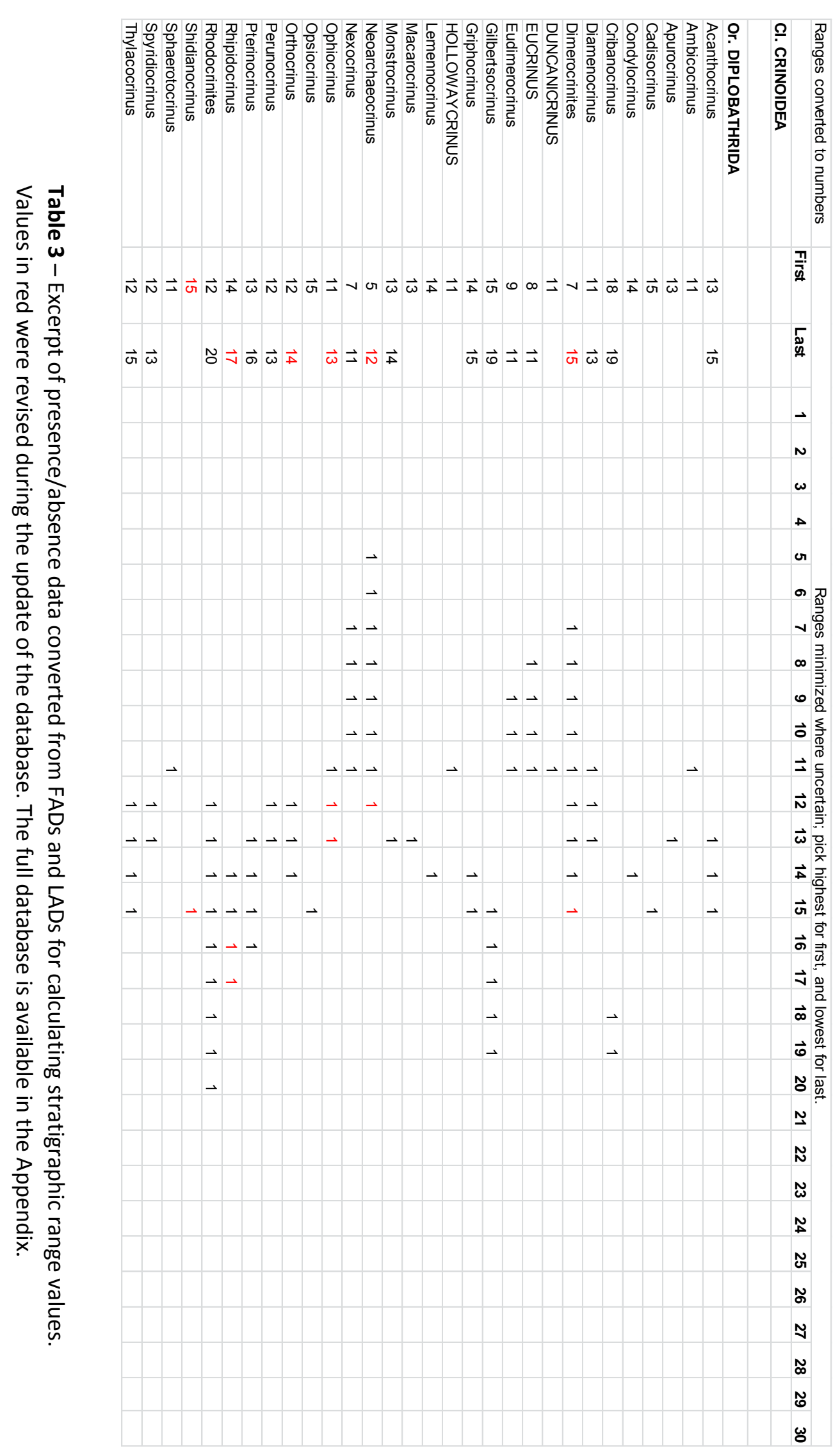




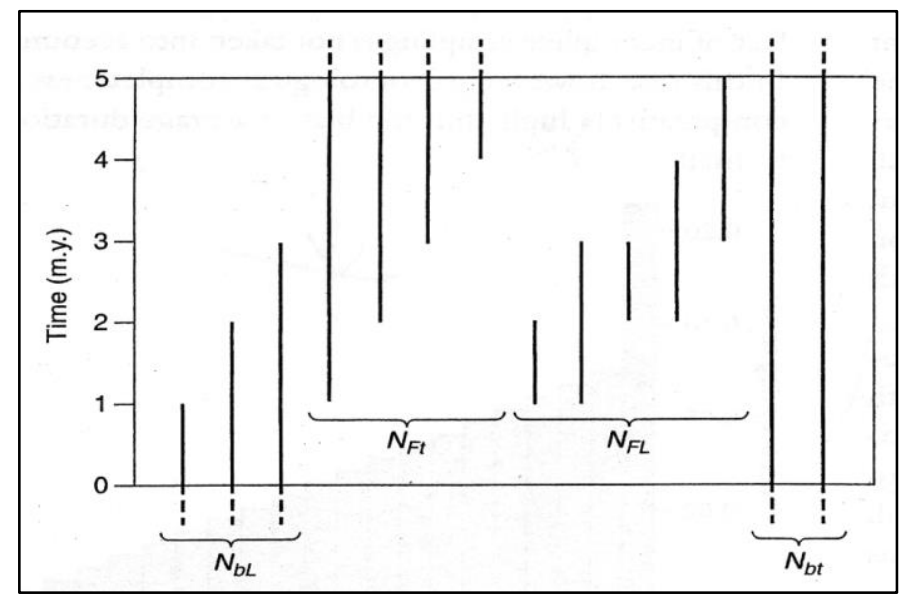

Figure 7 - Visual Representation of stratigraphic range values. This example has a stage with a duration of 5 m.y. (Foote and Miller, 2007).

\begin{tabular}{|lll|}
\hline Quantity & Symbol & \multicolumn{1}{c|}{ Equivalence } \\
& & \\
Taxa at beginning of interval & $N_{b}$ & $N_{b L}+N_{b t}$ \\
Taxa at end of interval & $N_{t}$ & $N_{F t}+N_{b t}$ \\
Total diversity in interval & $N_{\text {tot }}$ & $N_{b L}+N_{F t}+N_{F L}+N_{b t}$ \\
Number of first appearances & $N_{F}$ & $N_{F t}+N_{F L}$ \\
Number of last appearances & $N_{L}$ & $N_{b L}+N_{F L}$ \\
Proportional origination & $P_{O}$ & $N_{F} / N_{\text {tot }}$ \\
Proportional extinction & $P_{E}$ & $N_{L} / N_{\text {tot }}$ \\
Proportional origination per m.y. & $P_{\text {Om.y. }}$ & $P_{O} / \Delta t$ \\
Proportional extinction per m.y. & $P_{E m . y .}$ & $P_{E} / \Delta t$ \\
Per-capita origination rate per Lmy & $p$ & $-\ln \left(N_{b t} / N_{t}\right) / \Delta t$ \\
Per-capita extinction rate per Lmy & $q$ & $-\ln \left(N_{b t} / N_{b}\right) / \Delta t$ \\
\hline
\end{tabular}

Figure 8 - List of calculations possible from stratigraphic range values (Foote and Miller, 2007).

from the Artinskian to Wordian (Time bins 26-28) for a total of 12 stages. The LPIA evolutionary rates were calculated from the Serpukhovian to Sakmarian (Time bins 2025) for a total of six stages. While glaciation associated with the LPIA is projected to 
have begun in the Visean (Shi and Waterhouse, 2010; Montanez and Poulsen, 2013), it is interpreted as minor glaciation in the latest Visean, and is unlikely to have had an immediate impact on marine biodiversity. It is for this reason that the Visean is included in the calculations of background evolutionary rates instead of evolutionary rates during the LPIA.

\section{RESULTS}

The results of the analyses on the updated database of Devonian-Permian crinoid genera show that during the LPIA proportional origination and extinction rates of all crinoid clades were lower than background rates of origination and extinction (Figure 9). Stanley and Powell's (2003) graph (Figure 2) compared mean background evolutionary rates from the LPIA and background evolutionary rates. A similar graph (Figure 9) was created for this study comparing the mean PO/PE rates as percentages by interval of crinoid clades during the LPIA to mean background PO/PE rates as percentages by interval. All clades of Paleozoic crinoids have lower evolutionary rates (below the line of parity, Figure 9) during the LPIA as compared to background evolutionary rates. Lower diversity counts for all crinoid clades except advanced cladids occurred during the LPIA (Table 12). Stanley and Powell (2003) noted that diversity counts of marine invertebrates during the LPIA were lower than previous or following stages alongside the depressed rates of origination and extinction in marine invertebrates (Figure 1B and Figure 1A, respectively). The only clade with higher mean diversity during the LPIA is the advanced cladids (Table 12), with a LPIA diversity of almost three times their background diversity 


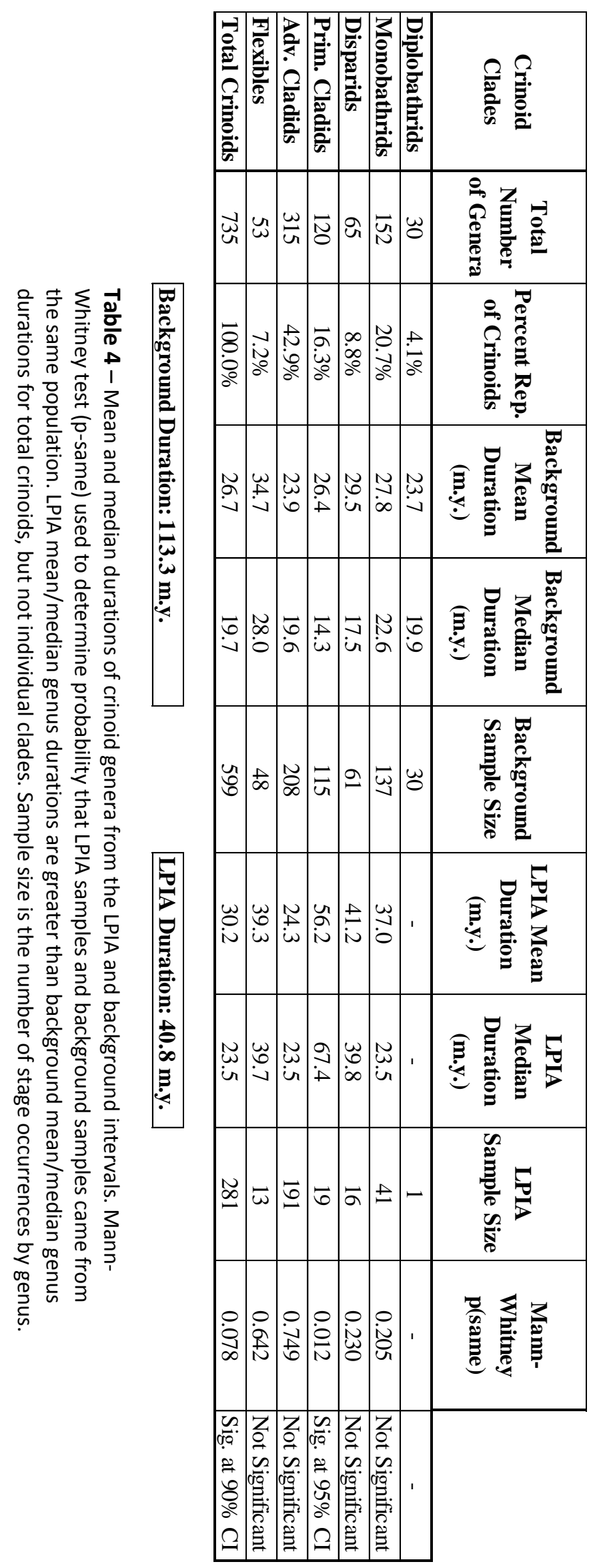




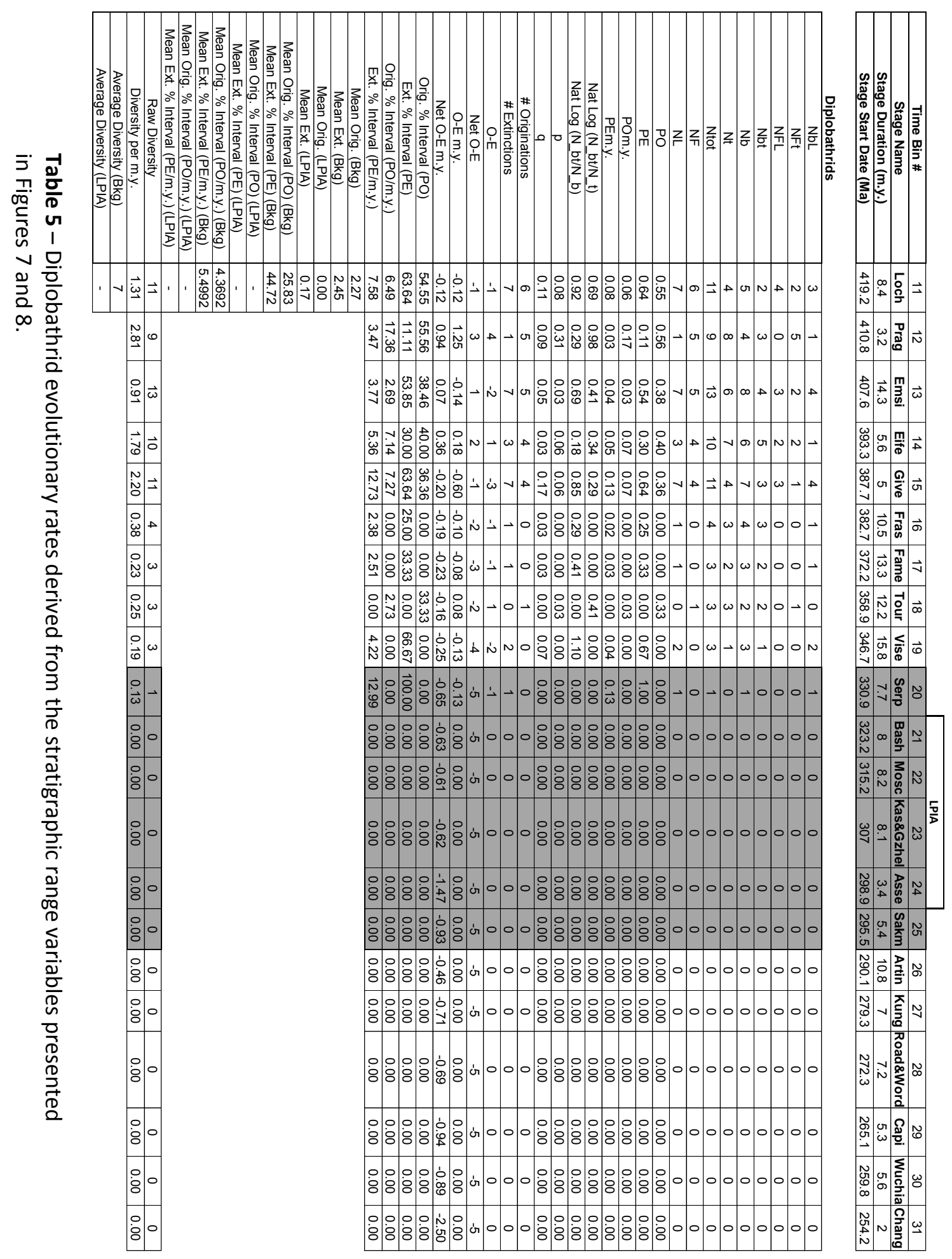




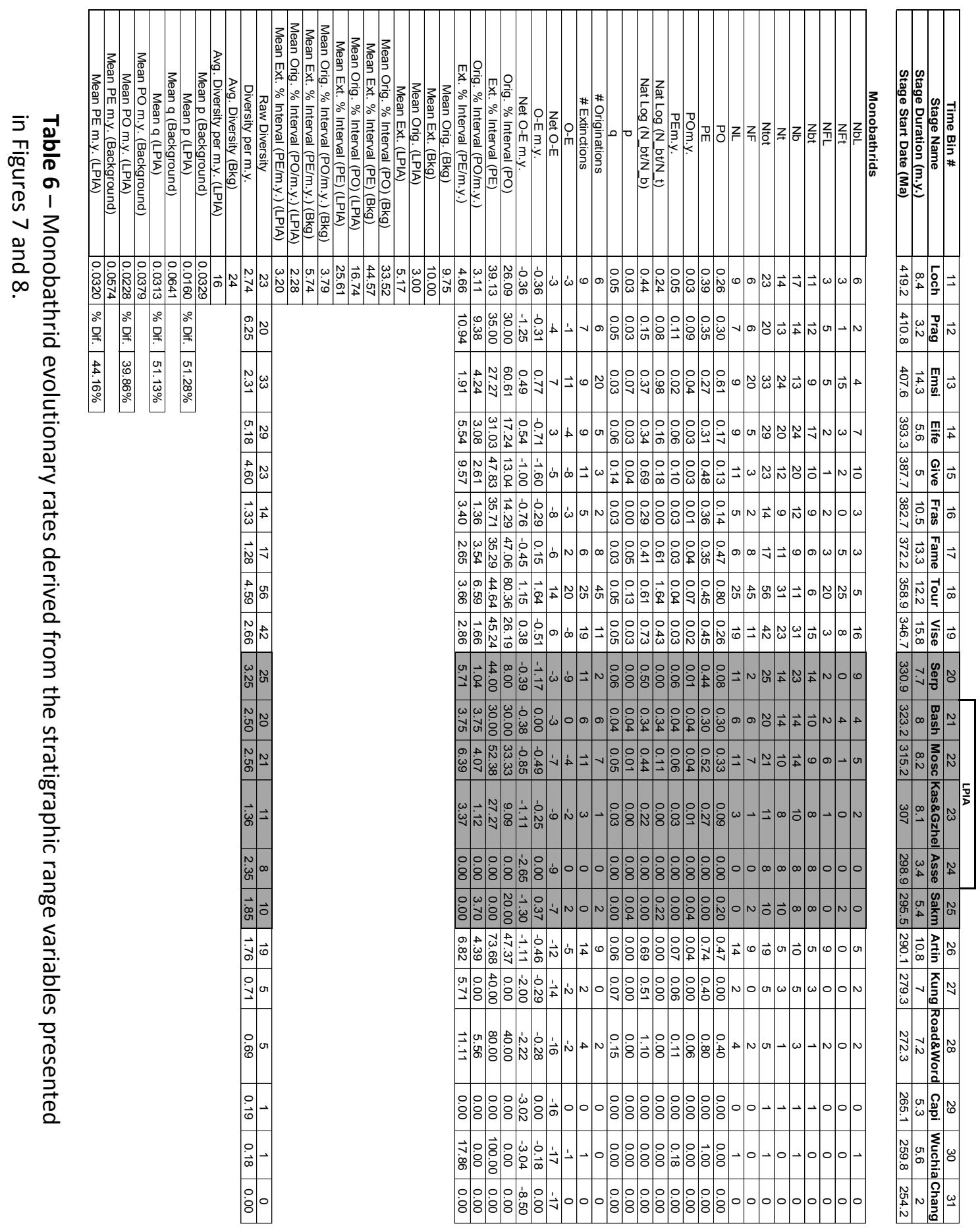




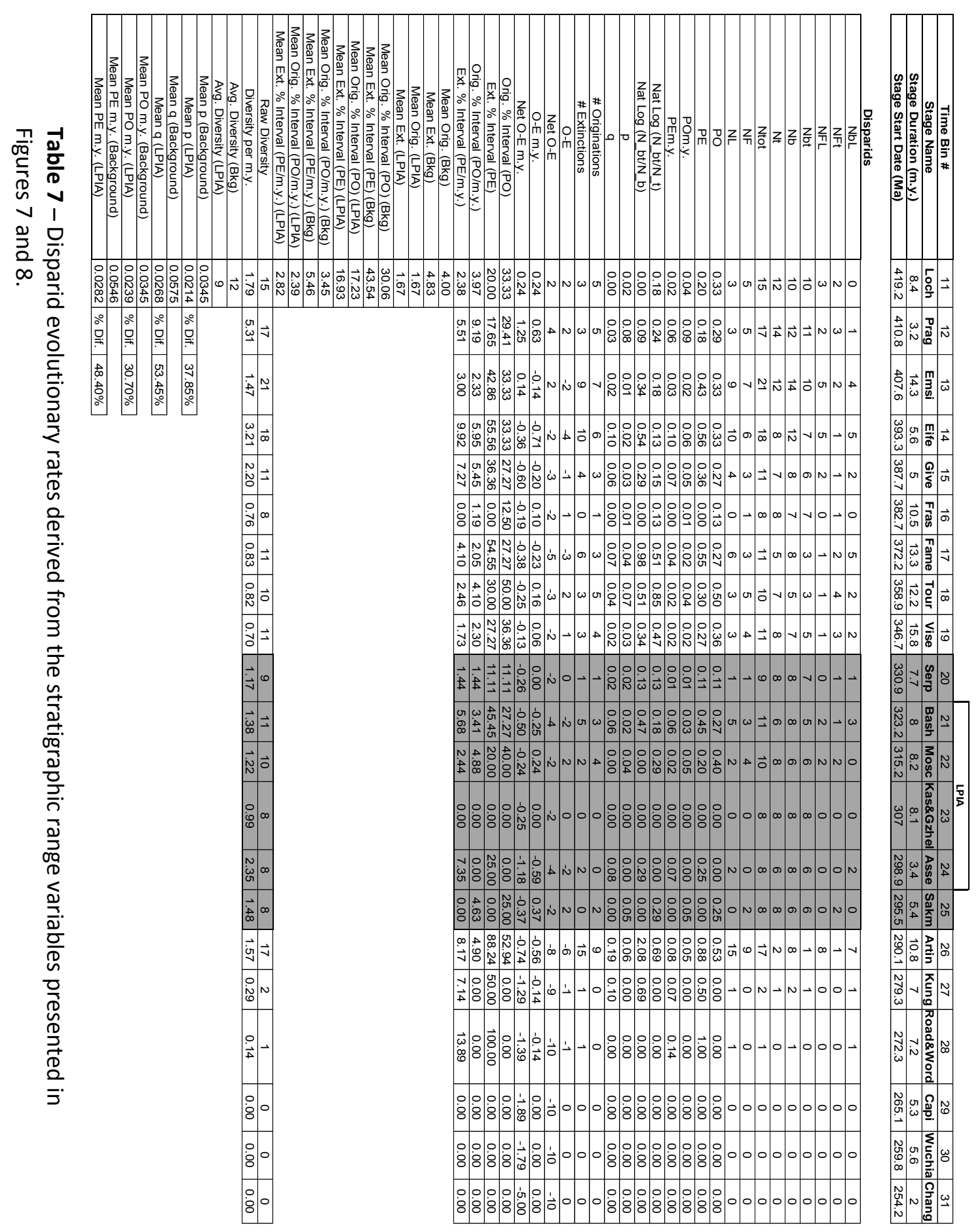




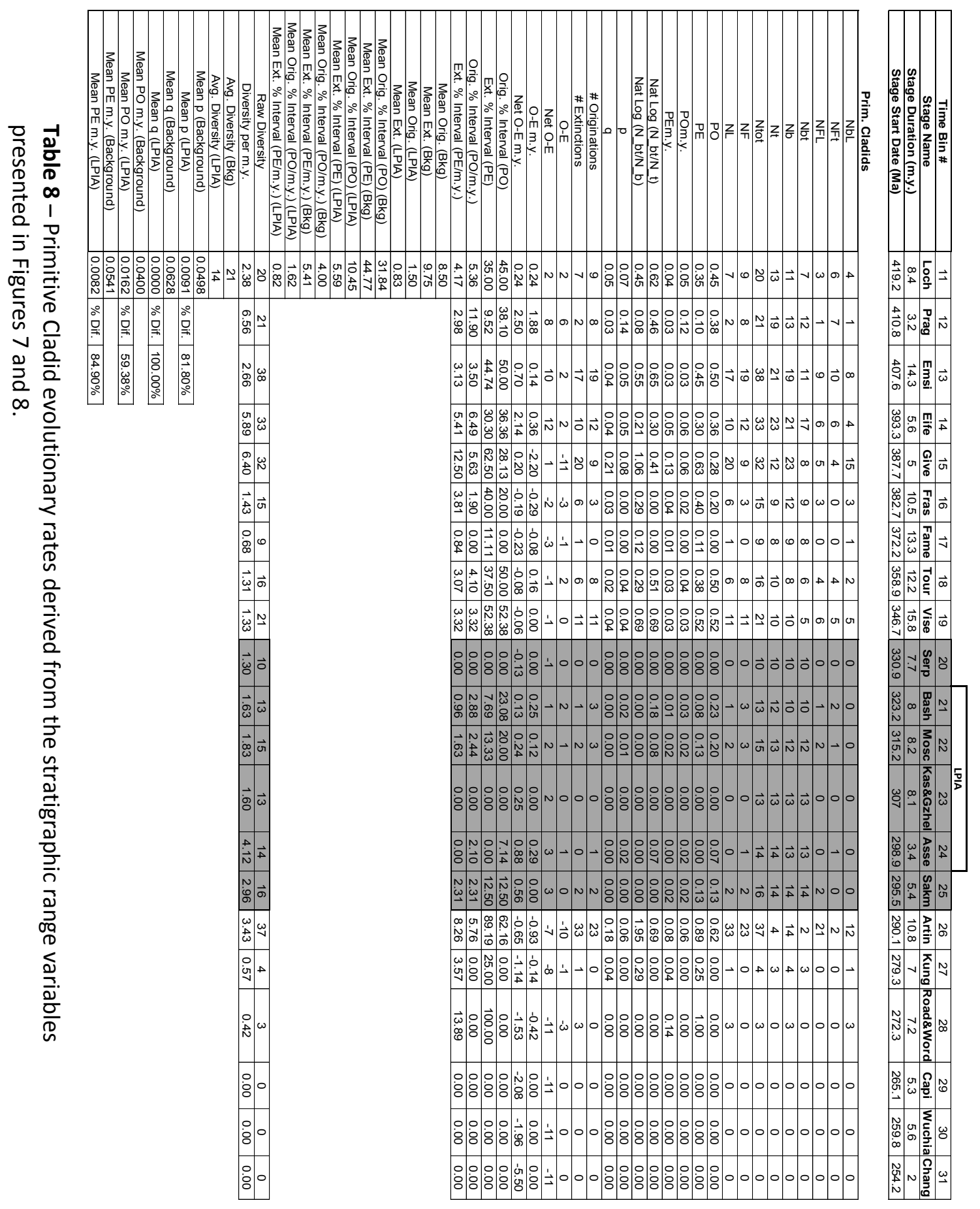



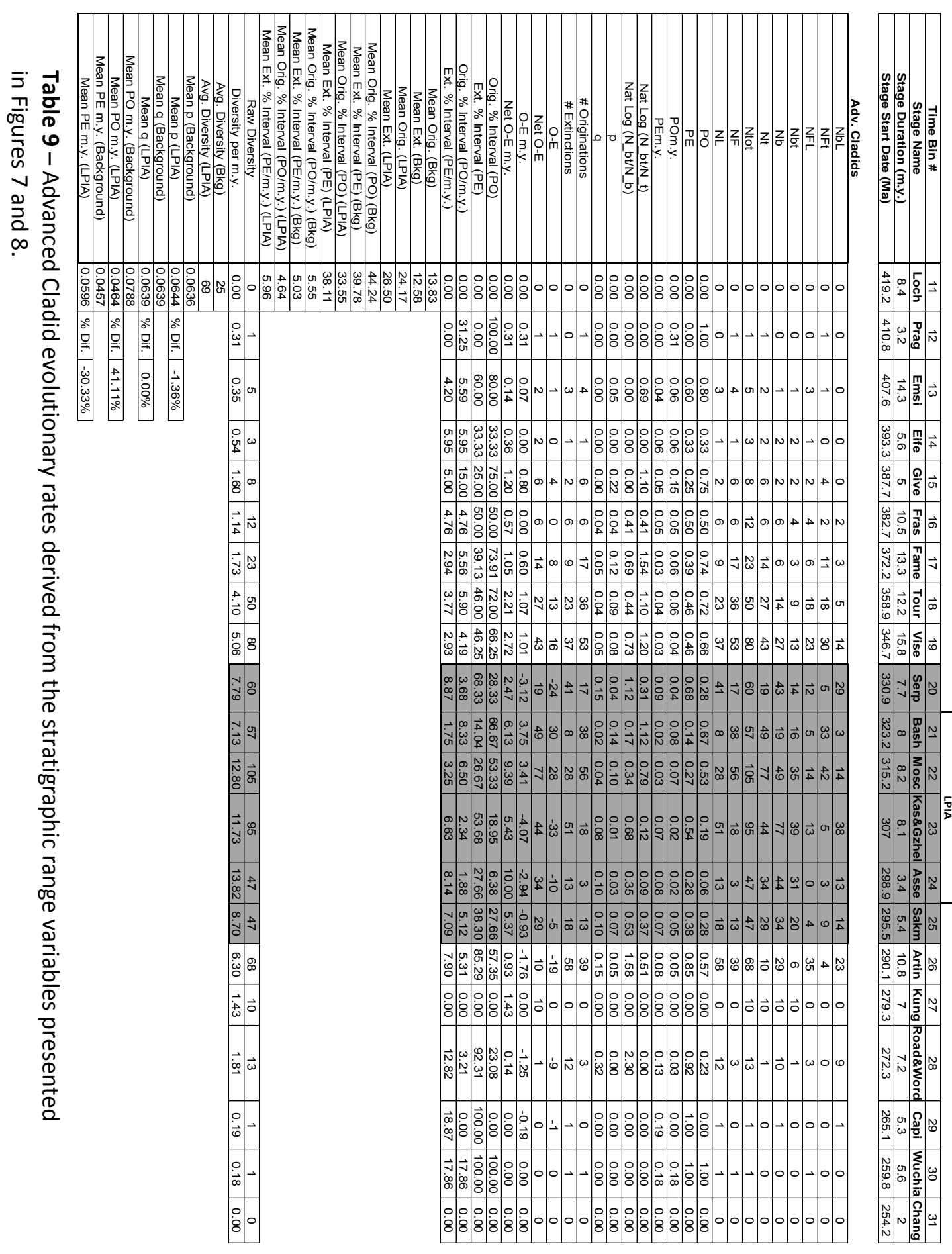


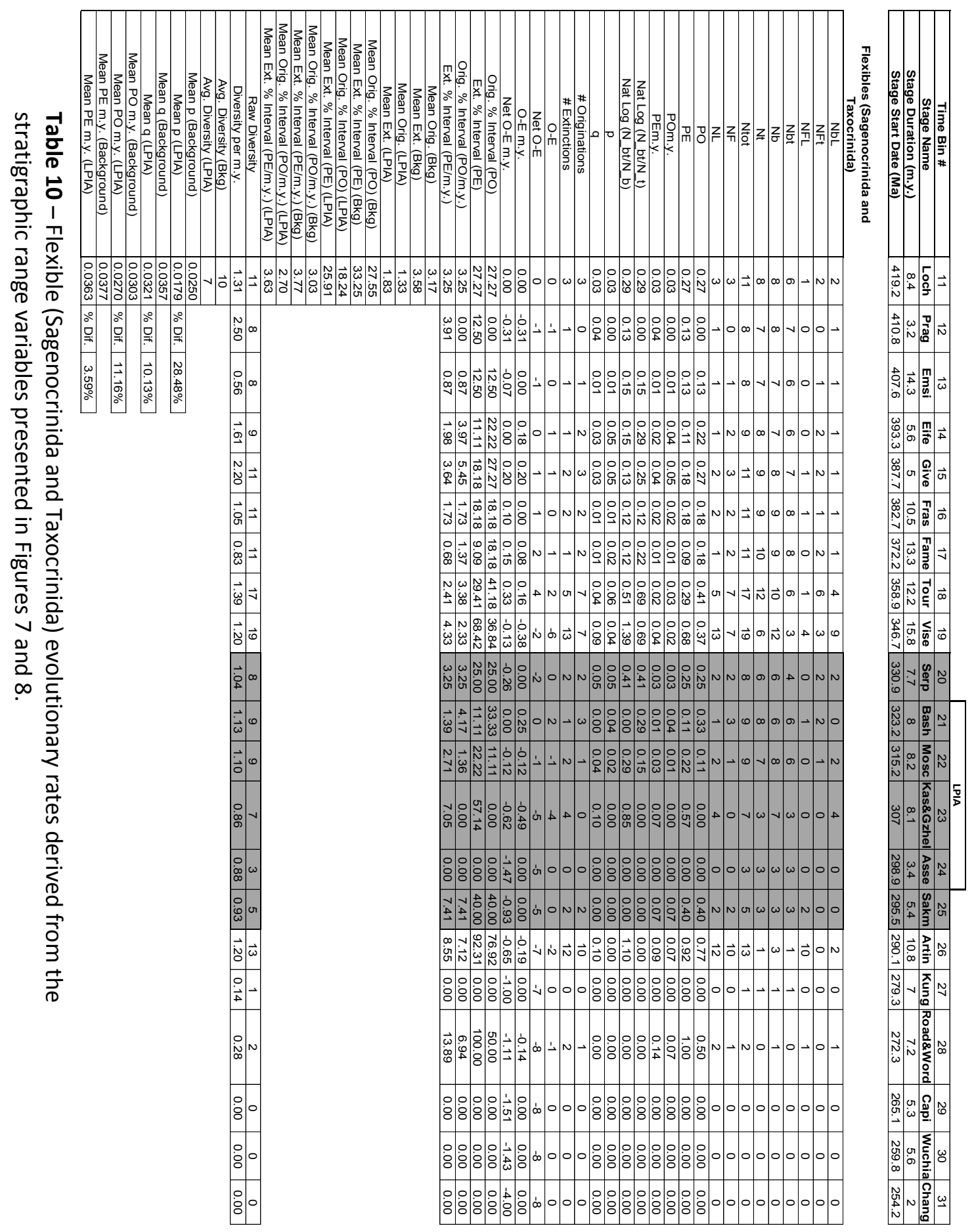




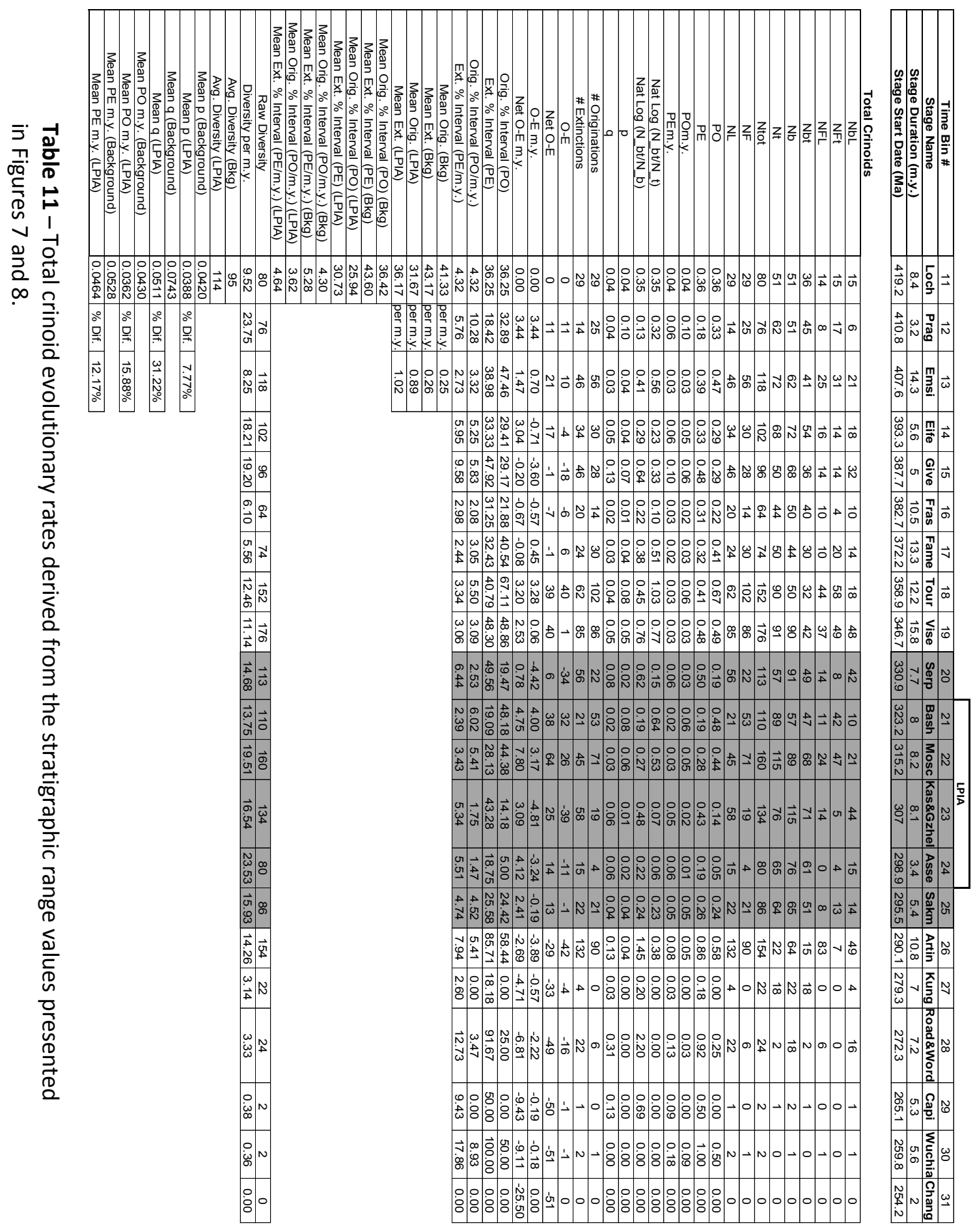


(25 and 69, respectively). The difference is large enough and the advanced cladids' diversity is high enough (particularly during the LPIA) that it drives up the total crinoid values of average diversity, even though all other clades have lower average diversity individually during the LPIA.

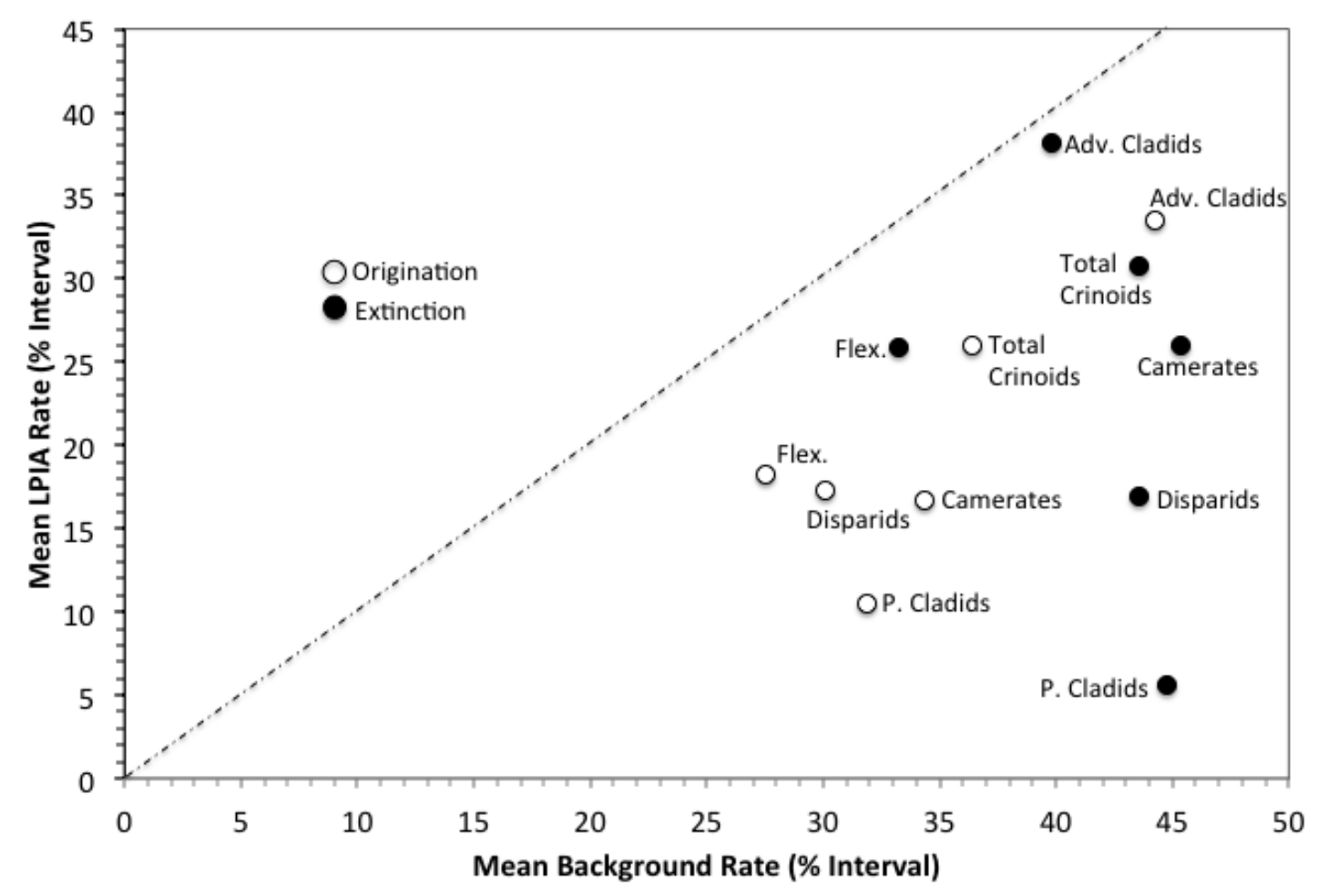

Figure 9 - Mean proportional rates of origination and extinction in crinoids (\% interval) during the LPIA vs. background rates of origination and extinction in crinoids (\% interval). The dashed line represents parity.

Another interesting result of the calculations is the difference between the mean and median genus durations (LPIA and background) of crinoid clades found in Table 4. All crinoid clades had higher mean and median genus durations among genera that lived during the LPIA than genera that lived during the background interval. The mean genus durations for the LPIA and background intervals were statistically tested for significance using a non-parametric Mann-Whitney test on the program PAST. A t-Test of the mean 
genus durations was not used because the distributions of the mean genus durations are not a normal distribution. While the total crinoids show a statistically significant difference (90\% CI, Table 4), all clades except the primitive cladids have results that are not significant. The primitive cladids' statistical significance is likely an artifact because primitive cladid genera that existed through the LPIA are almost exclusively microcrinoids, which may artificially extend their time ranges. In summary, the total crinoid record supports the idea of higher mean and median genus durations during the LPIA, but it is not a strong signal.

\begin{tabular}{|lcc|}
\hline & Background & LPIA \\
Diplobathrids & 7 & - \\
Monobathrids & 24 & 16 \\
Disparids & 12 & 9 \\
Primitive Cladids & 21 & 14 \\
Advanced Cladids & 25 & 69 \\
Flexibles & 10 & 7 \\
Total Crinoids & 95 & 114 \\
\hline
\end{tabular}

Table 12 - Mean background diversity of crinoids and mean diversity of crinoids during LPIA. Advanced cladids are the only crinoid clade with a higher mean diversity during the LPIA as compared to mean background diversity.

The net origination and extinction of crinoids during the LPIA was examined as part of the analysis (Figure 10). The difference between the rates of origination and extinction were calculated using raw counts of originations and extinctions of each clade by stage. All clades except the advanced cladids experienced relatively stable net origination-extinction during the LPIA (Net origination close to 0, Figure 10). The advanced cladids' net origination-extinction sharply decreased at the start of the LPIA (Serpukhovian) and peaked during the Bashkirian and Moscovian. After the Moscovian, the net origination-extinction for advanced cladids falls sharply with more extinctions 
than originations for the remainder of the LPIA. The net origination-extinction helps explain the apparent discrepancy between advanced cladids' evolutionary rates (higher extinction than origination, Figure 9) and the advanced cladids' higher mean diversity during the LPIA (Table 12). The comparatively high number of originations for advanced cladids in the Bashkirian and Moscovian (within the LPIA) combined with genera surviving from the origination increase from the Frasnian to the Visean (stages preceding LPIA) would have contributed to a high diversity count for them during the LPIA.

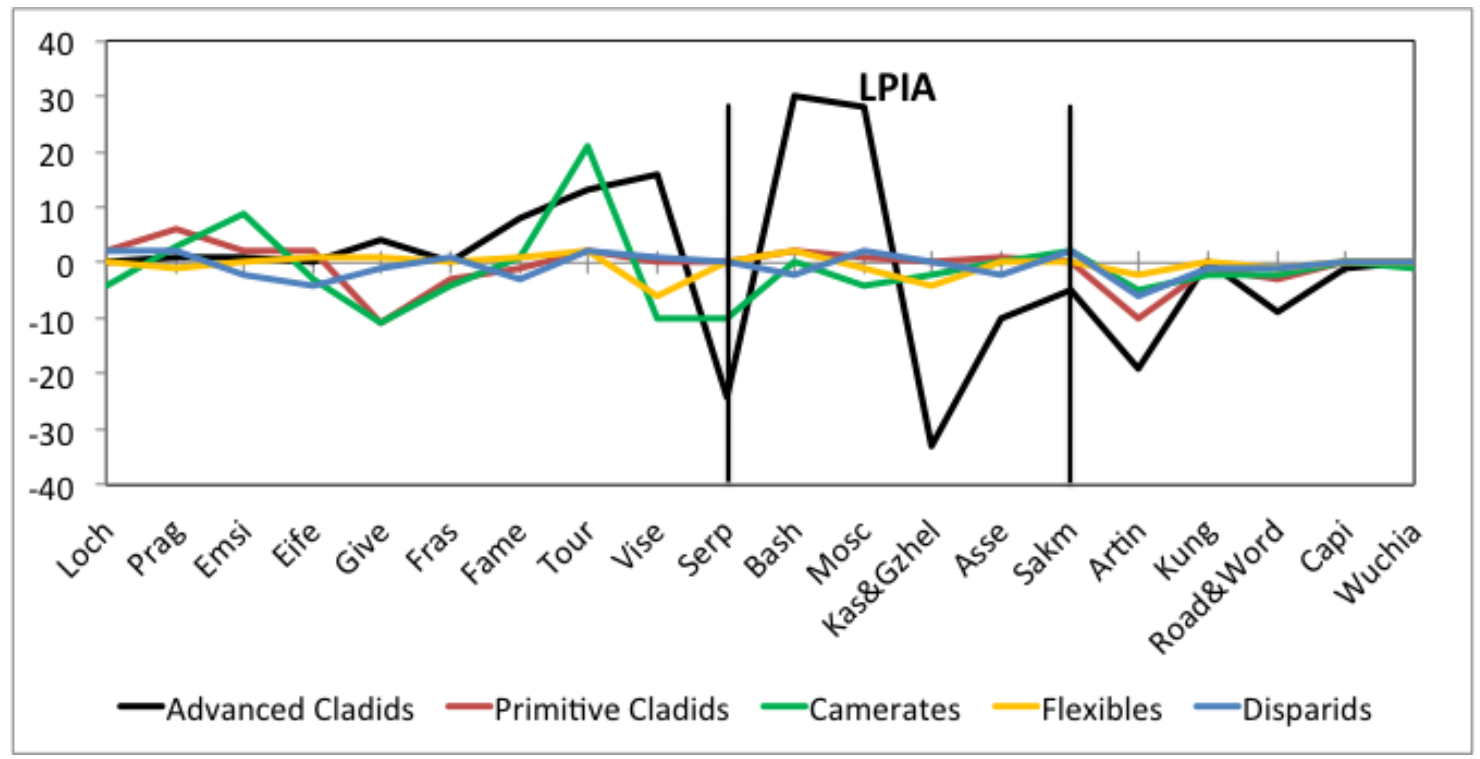

Figure 10 - Net change in genera (origination minus extinction) of Paleozoic crinoid clades by stage starting in the Lochkovian. (Raw Originations - Raw Extinctions). The end values are the net loss of genera that entered the Devonian from the Silurian. Camerates are the combined Diplobathrida and Monobathrida data.

Evolutionary rates and diversity counts cannot be directly compared, particularly when dealing with smaller numbers (advanced cladid diversity in the Devonian) that grow into larger numbers (advanced cladid diversity during the LPIA). Because the advanced cladids originate within the study interval, their early evolutionary rates appear 
higher in the Devonian and lower during the LPIA. When going from one genus to two, there is a $100 \%$ increase, as is seen in the advanced cladids' beginning (Lochkovian). A one genus change however, is a low magnitude difference. When there are 57 genera (advanced cladids, Bashkirian) and there are 105 genera in the following stage (advanced cladids, Moscovian), the percent increase is only $84 \%$ despite being an increase of 48 genera. The difference in magnitude between the advanced cladids' diversity at the beginning of the study interval and during the LPIA causes the discrepancy between their evolutionary rates and diversity counts in the study interval.

Evolutionary rates of each crinoid clade were plotted individually and together to compare them throughout the study interval. The proportions of origination and extinction (Figure 11) and the per-capita origination/extinction (Figure 12) were plotted for each crinoid clade. Diversity counts of crinoid clades are plotted in Figure 13. Total crinoid diversity and evolutionary rates were also calculated and plotted for the proportional evolutionary rates and the per-capita evolutionary rates (Figure 14). Also included in the analysis was an examination of crinoid proportional diversity (Figure 15) to highlight the pull of the advanced cladids on total crinoid calculations.

A consideration to be made when looking at stage level data is to determine if calculated rates of evolution are skewed because stages contain uneven amounts of time. For instance, the Visean represents 15.8 million years of time, while the following Serpukhovian represents less than half that at 7.7 million years. The raw diversity of the Visean (173 crinoid genera) is greater than that of the Serpukhovian (113 crinoid genera), and if plotted on a graph by stage, the Visean would appear to be more significant in terms of raw diversity. When normalized to a million years (Diversity/Stage Duration) 
the Serpukhovian has a higher degree of diversity, at 15 genera per million years, compared to the Visean's 11 genera per million years. However, the data used to calculate the evolutionary rates for this study is based on FADs and LADs by stage for each genus. Without knowing the exact origination/extinction dates of each individual genus, using per million year data can distort the data, giving more 'weight' to genera that only existed within a stage for a short period of time as compared to a genus that existed throughout the entire stage. This problem with uneven stage durations when calculating evolutionary rates is manifested in the apparent contradiction of increasing diversity of advanced cladids during the LPIA (Figure 13E) when the mean extinction rate is higher than the mean origination rate (Figure 9).

\section{DISCUSSION}

\section{Advanced Cladids are Exceptional}

The results of the analyses on Paleozoic crinoids support Stanley and Powell's (2003) hypothesis that evolutionary rates in marine invertebrates were depressed during the LPIA when compared to background evolutionary rates. All Paleozoic crinoid clades had lower rates of evolution during the LPIA than before or after it (Figure 9). Paleozoic crinoids also match Stanley and Powell's (2003) observation of lower diversity in marine invertebrates during the LPIA with one exception: the advanced cladids (Table 12). The advanced cladids experienced a peak in diversity during the LPIA, specifically during the Moscovian (Figure 13E). While the advanced cladids have evolutionary trends opposite 


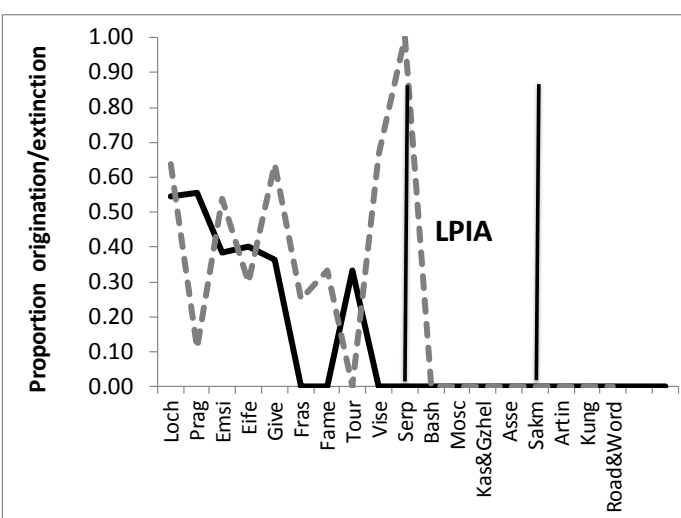

A. -Diplobathrid PO -- Diplobathrid PE

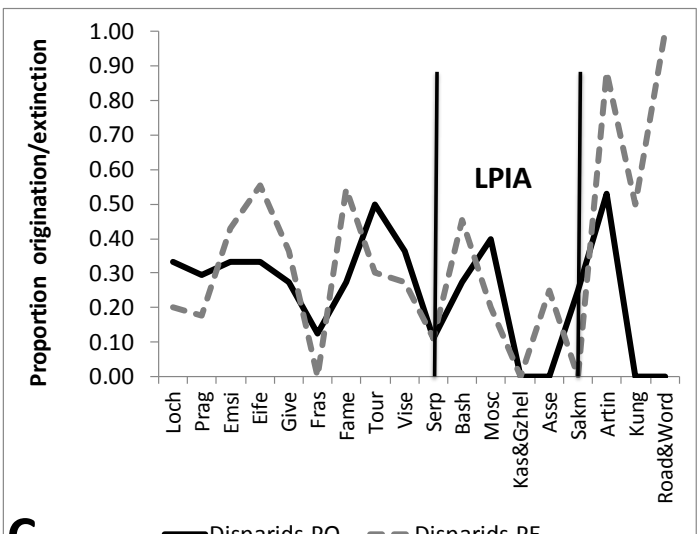

C. -Disparids PO $\quad-$ Disparids PE

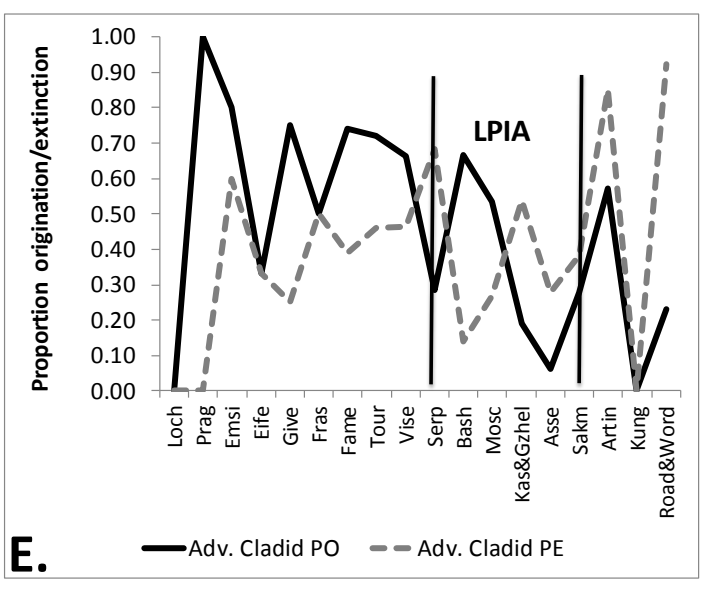

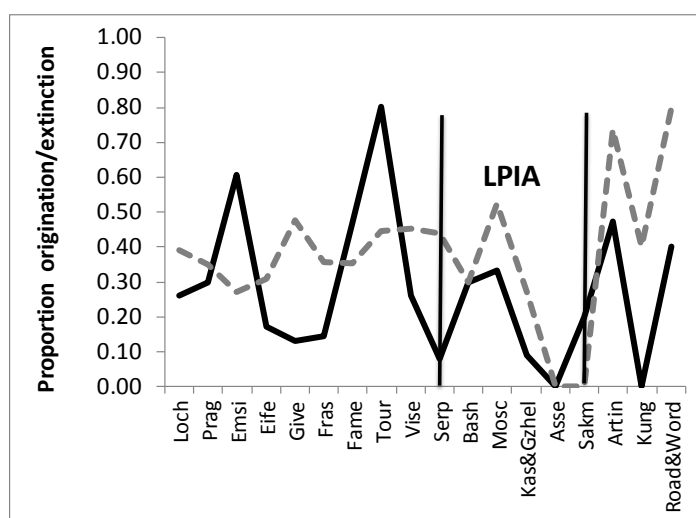

B. -Monobathrid PO --Monobathrid PE

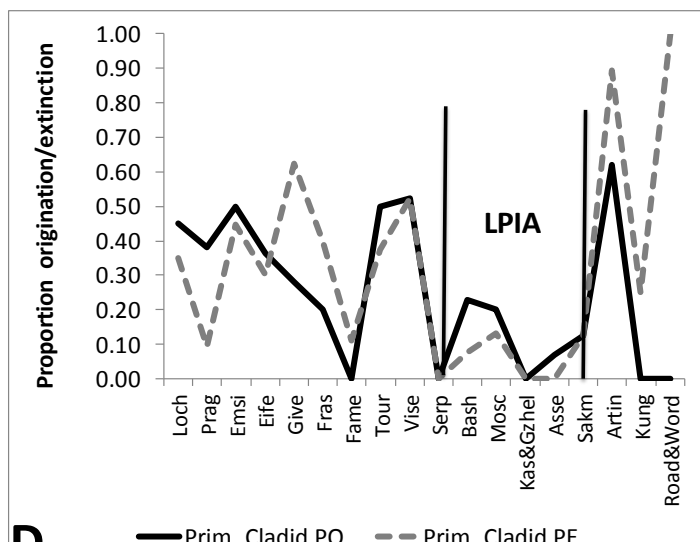

D.

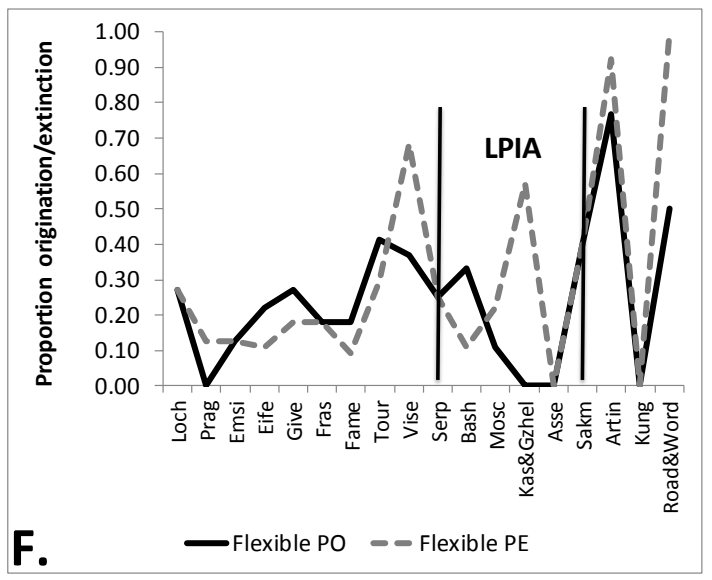

Figure 11 - Proportion origination and extinction (PO and PE, respectively) of each crinoid clade. Proportion origination and extinction calculations use 'singletons' and are calculated by stage. (A) graph representing diplobathrids; (B) graph representing monobathrids; (C) graph representing disparids; (D) graph representing primitive cladids; (E) graph representing advanced cladids; and (F) graph representing flexibles. 

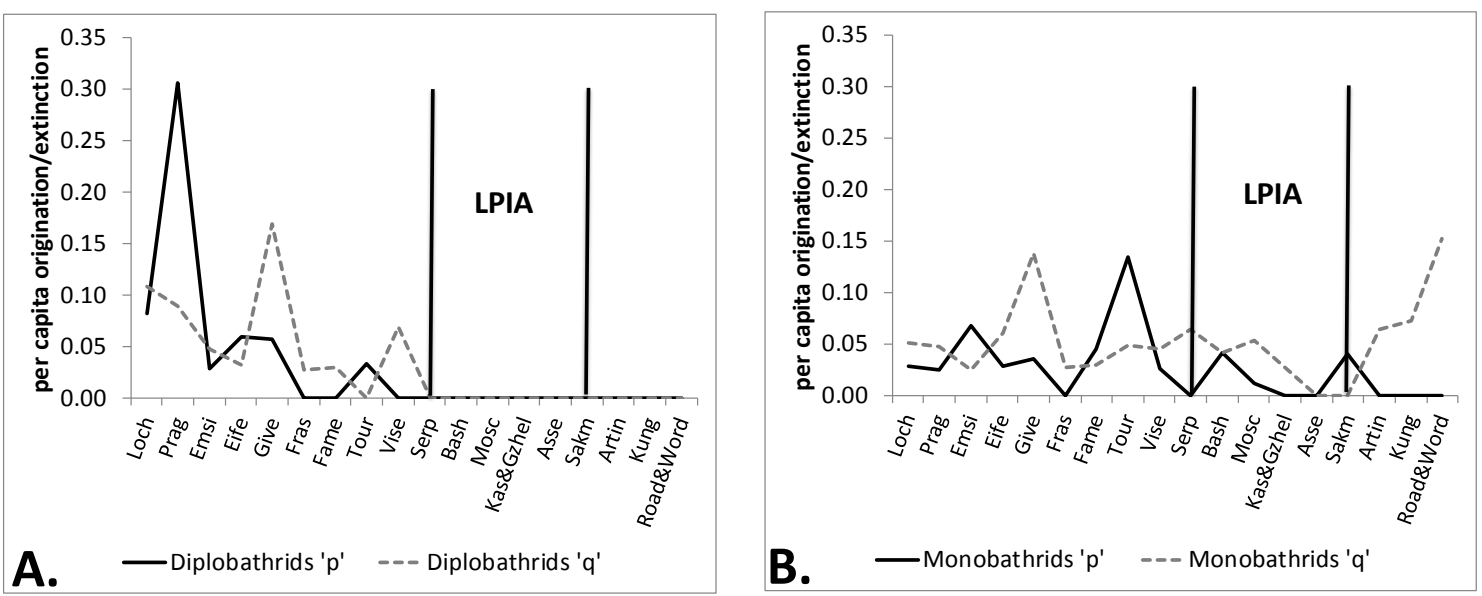

A. - Diplobathrids ' $p$ ' --- Diplobathrids ' $q$ '

B. - Monobathrids ' $p$ ' --- Monobathrids ' $q$ '
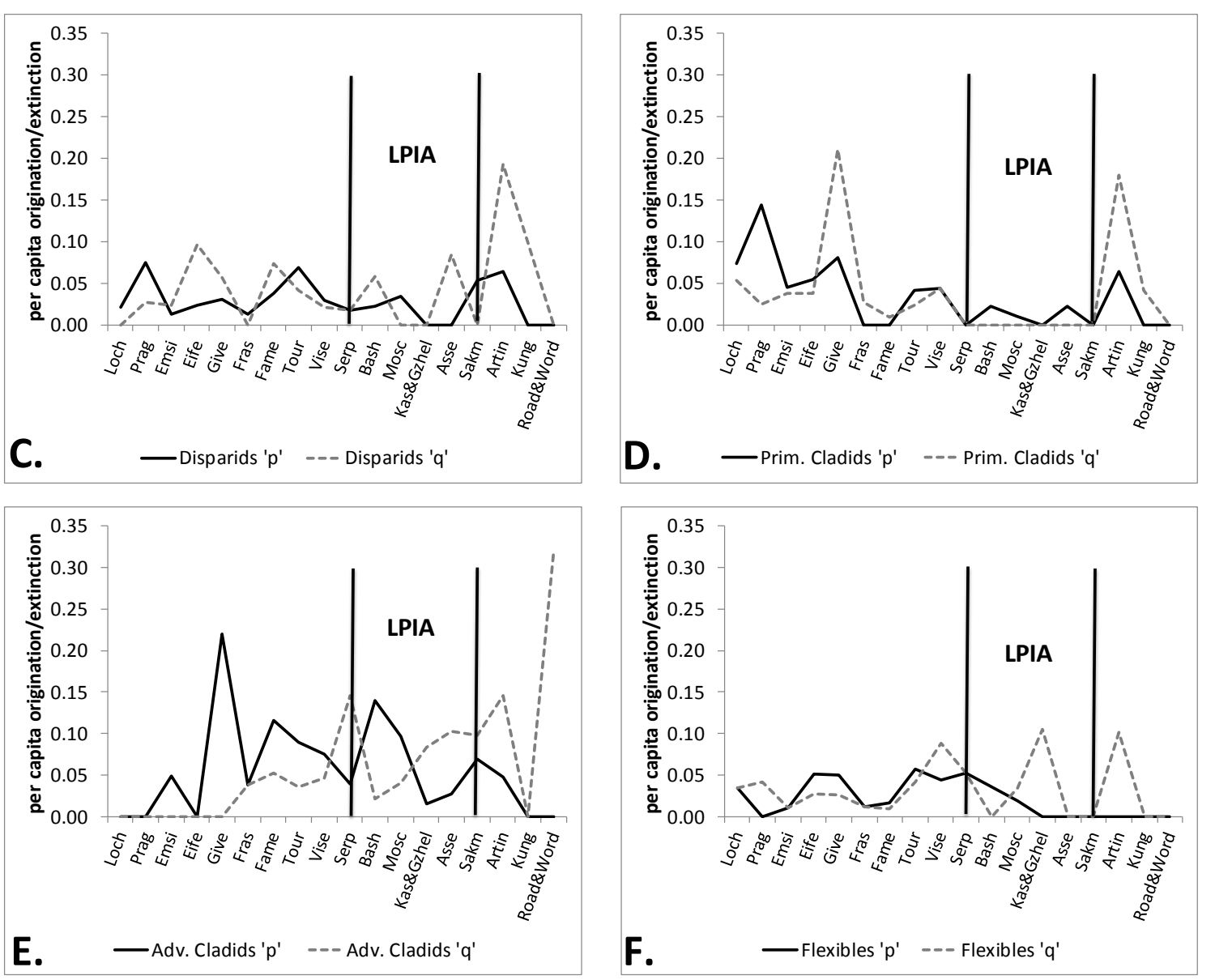

Figure 12 - Per-capita origination and extinction ( $p$ and $q$, respectively) of each crinoid clade. Per-capita origination and extinction calculations exclude singletons, and are calculated per million years. (A) graph representing diplobathrids; (B) graph representing monobathrids; (C) graph representing disparids; (D) graph representing primitive cladids; (E) graph representing advanced cladids; and (F) graph representing flexibles. 

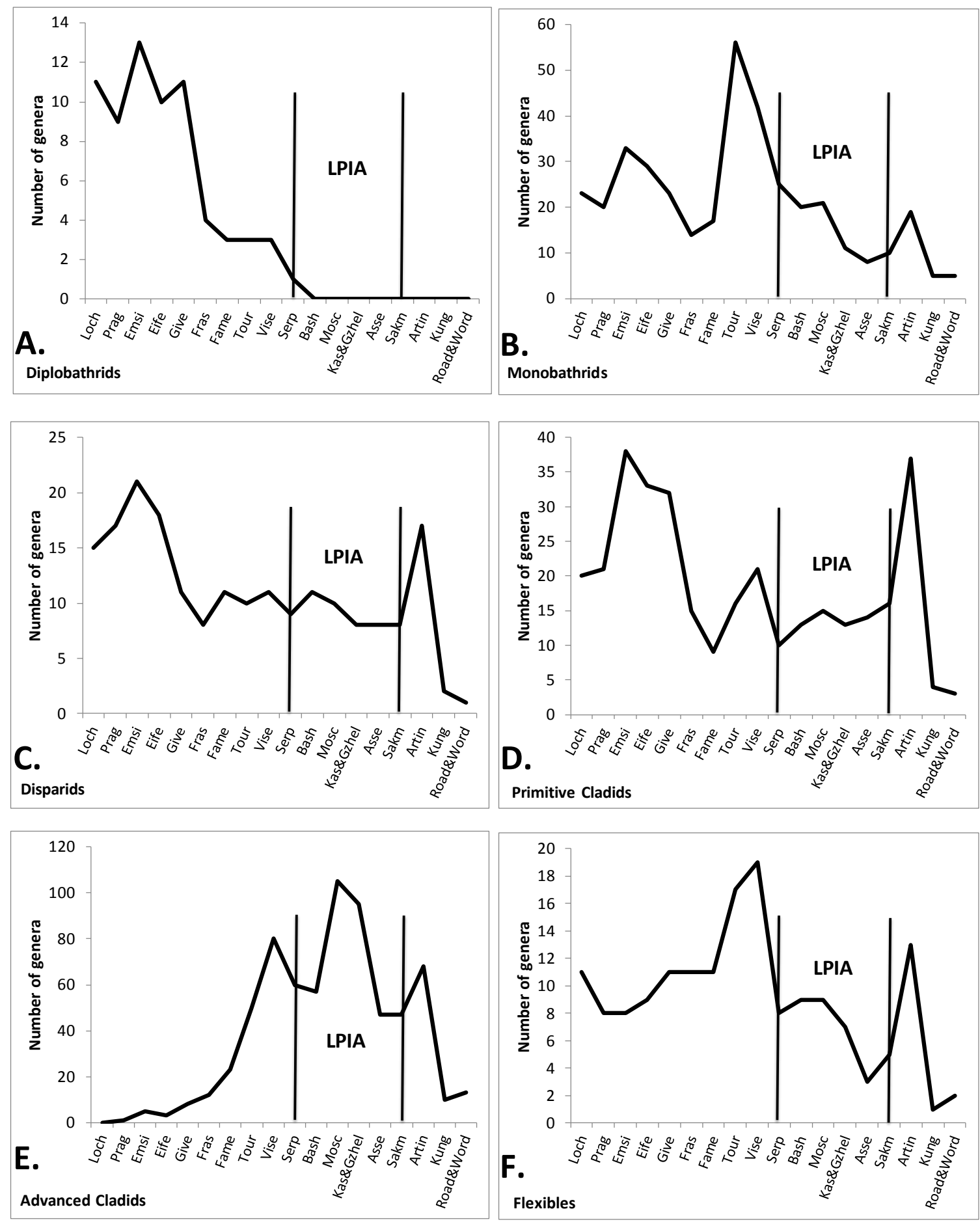

Figure 13 - Raw diversity counts of each crinoid clade by stage from the Earliest Devonian to the Middle Permian. (A) graph representing diplobathrids; (B) graph representing monobathrids; (C) graph representing disparids; (D) graph representing primitive cladids; (E) graph representing advanced cladids; and (F) graph representing flexibles. 

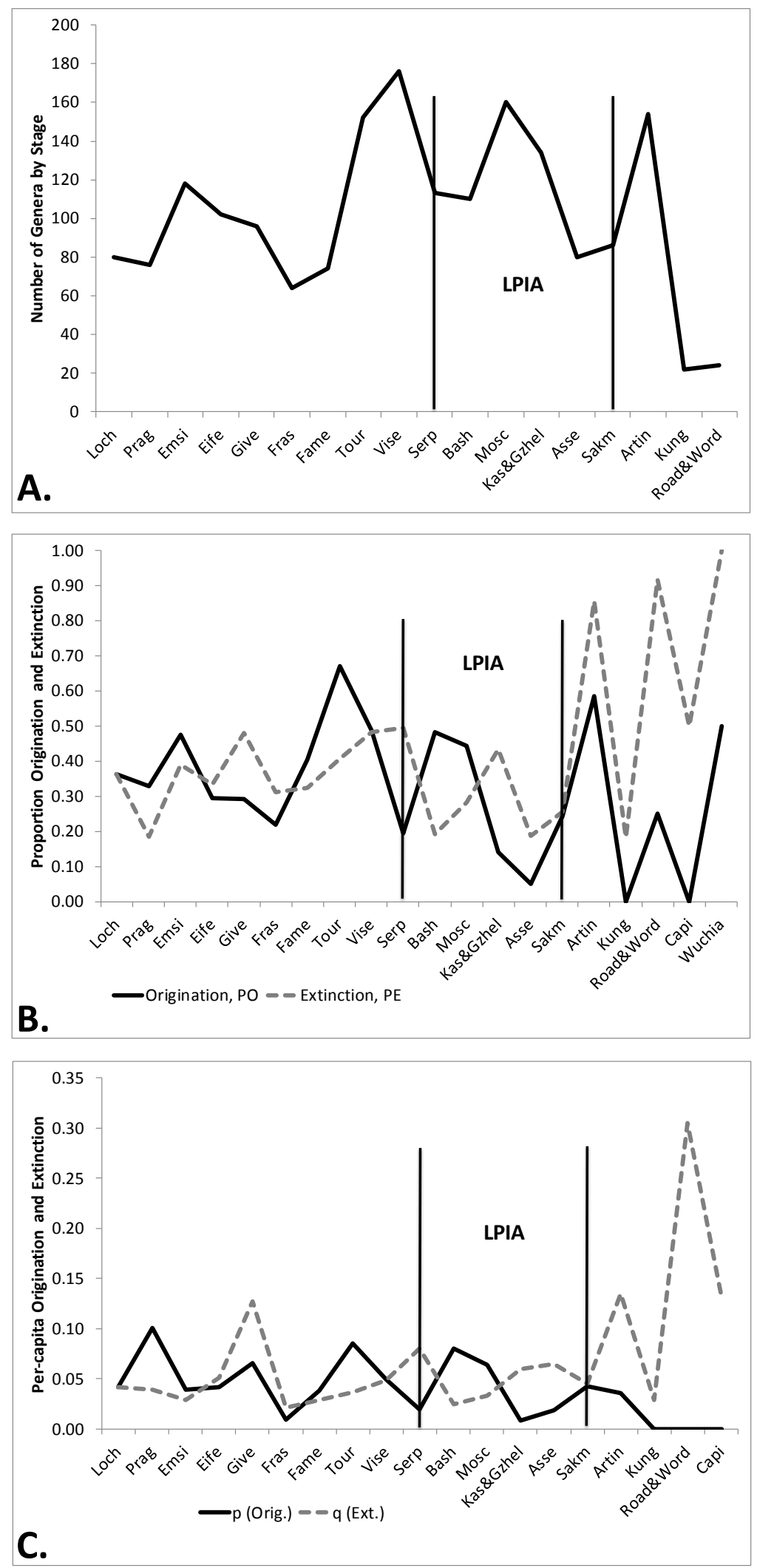

Figure 14 - Evolutionary rates and diversity count of all Paleozoic crinoids. (A) diversity by stage of total crinoids. (B) proportion origination and extinction of total crinoids by stage. (C) per-capita origination and extinction of total crinoids. 


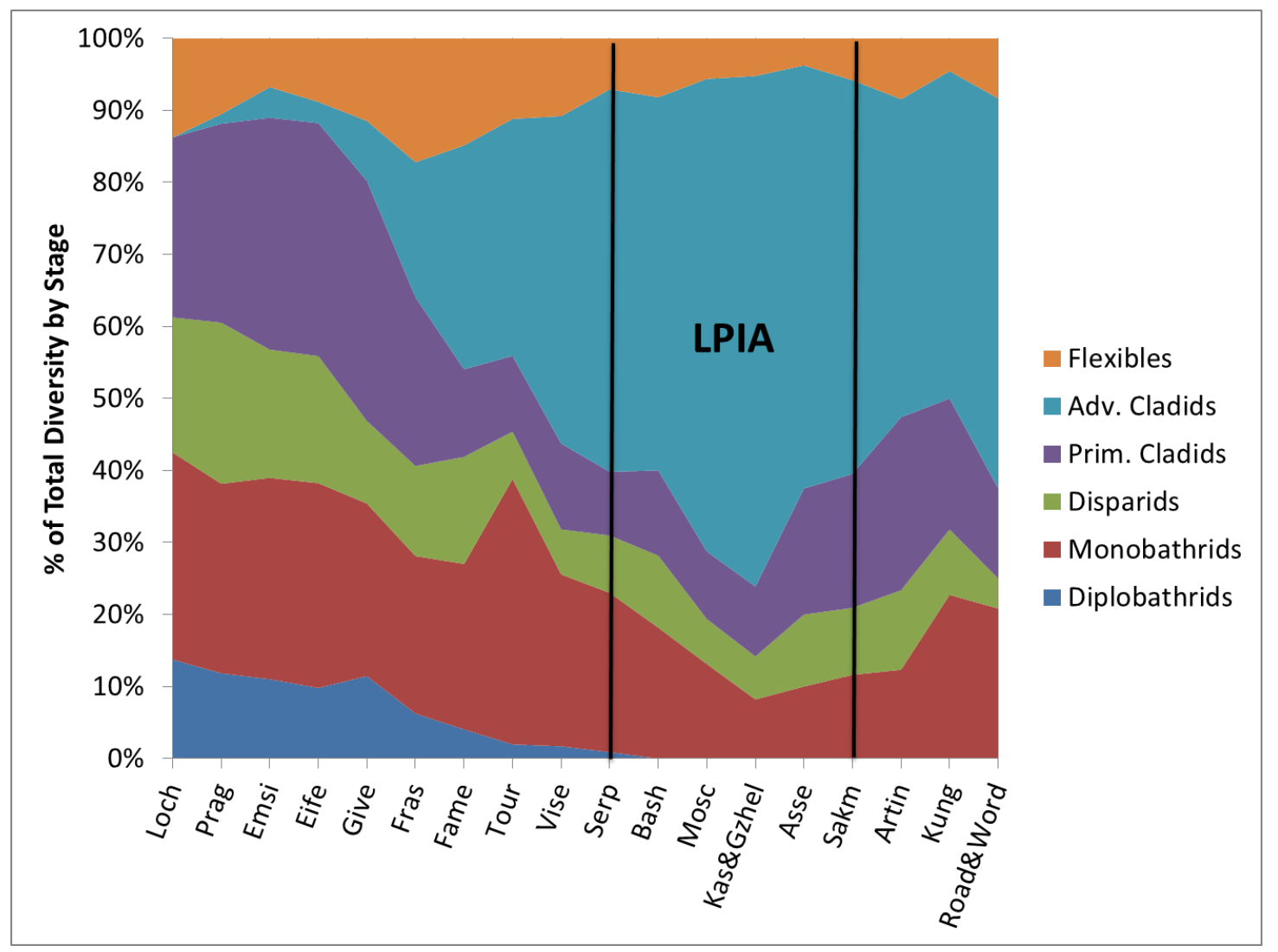

Figure 15 - Diversity count by stage of Paleozoic crinoids expressed as percentages of total crinoids through the study interval. Note the advanced cladids' dominance during the LPIA.

of what is expected by Stanley and Powell's (2003) hypothesis, it likely does not indicate a flawed hypothesis but rather an exception. The advanced cladids evolutionary trends are likely caused by unique morphology and specific environmental conditions they were better adapted to than other crinoid clades.

A likely driver for the advanced cladids' rise was their adaptation to the increase in siliciclastic-dominated depositional environments in response to the formation of Pangaea, specifically the Alleghenian Orogeny, which overlapped in time with the LPIA. (Kammer et al., 1998; Smith and Read, 2000; Ettensohn et al., 2002). The advanced cladids were the only Paleozoic crinoid clade with muscular arm articulations between 
arm plates, whereas other Paleozoic crinoids had strictly ligamentary articulations (Ausich and Baumiller, 1993). Compared to mutable collagen ligamentary articulations, muscular arm articulations would have allowed for advanced cladids to move their arms more rapidly (Kammer and Ausich, 2006). The advantage of faster arm movement would be a flicking motion that would enable advanced cladids to clear their arm fans of sediments more easily than other clades of crinoids. This ability would have allowed the advanced cladids to be more tolerant of high-turbidity siliciclastic settings than clades such as the camerates, which had slower moving arms in their denser filtration fans (Kammer et al., 1998).

However, it is not likely that advanced cladids competitively displaced camerates, as the two clades had different environmental preferences. Camerates preferred the carbonate-ramp settings of the Tournaisian and Visean, when they reached peak diversity (Figure 13B) whereas advanced cladids appeared well adapted to environments with higher siliciclastic influx (Kammer and Ausich, 2006). More likely than competitive displacement is that as the carbonate-dominated depositional environments declined and siliciclastic-dominated depositional environments increased in the Middle to Late Mississippian due to the Alleghenian Orogeny (Smith and Read, 2000; Ettonsohn et al., 2002), the habitats available to camerates shrank as the habitats available to advanced cladids expanded. The advanced cladids responded opportunistically to this environmental change, and became the dominant clade of crinoids during the LPIA.

\section{Decreased Rates of Origination and Extinction}

All crinoid clades experienced reduced rates of evolution during the LPIA (Figure 9), and all clades except the advanced cladids experienced reduced diversity 
counts during the LPIA (Table 12). The question then stands: "What potential drivers can cause reduced rates of origination and extinction in crinoids during the LPIA?" Stanley and Powell (2003) had two main hypotheses for the decreased rates of origination and extinction in marine invertebrates during the LPIA. The first hypothesis they offered was that environmental conditions during the LPIA induced lower capacities in marine habitats to support various ecosystems. Essentially, the cooling temperatures of the LPIA could have decreased the global carrying capacity of marine environments, creating more competition among marine benthos and leading to extinction caused by competitive stress. However, competitive exclusion among marine benthos is unusual, which is supported by the lack of competitive exclusion between the camerates and the advanced cladids. Another issue with the hypothesis of increased competition initiated by LPIA environmental shifts is that while it would account for lowered rates of origination, it would fail to explain lowered rates of extinction.

The second hypothesis put forward (and favored) by Stanley and Powell (2003), which is further explored by Powell (2005), is that environmental conditions during the LPIA reduced the probabilities of both origination and extinction. Rates of origination and extinction generally follow the same trend, because they are usually caused by similar biological traits (Stanley, 1990). The probabilities of origination and extinction would be reduced because marine invertebrates that survived the initiation of the LPIA and those that originated during the LPIA were more likely to be $r$-selected (opportunistic) genera. The traits of these $r$-selected marine invertebrates would include: (1) a wide ecological adaption, which would allow them to live in a wide range of environments which favors survival, but not origination through isolation or separation; 
(2) abundant, stable populations which have longer mean and median durations which are less likely to be disrupted and less likely to split and allow for new species and genera to develop (Stanley and Powell, 2003; Powell, 2005).

Powell (2005) tested reduced probabilities of origination and extinction by examining the geographic range of brachiopods during the LPIA and how they were distributed through time. The results of Powell's (2005) study supports the hypothesis that opportunistic taxa were more prevalent during the LPIA, resulting in decreased rates of origination and extinction. Brachiopod genera with shorter (41-60 m.y. and lower) median genus durations are very rare during the LPIA as compared to background intervals whereas genera with longer median durations (61-100 m.y. and up) are still common (Figure 16). A study of Paleozoic trilobites reflects the paleoecologic trends predicted by the reduced probability of evolutionary change hypothesis (Brezinski, 1999). Origination and extinction rates of trilobites declined with the onset of the LPIA and new trilobite species originating in the LPIA had wide ecological ranges.

Crinoids that lived during the LPIA had slightly greater mean and median durations (3.5 and 3.8 million years respectively, Table 4), indicating that crinoids may have followed a similar pattern to brachiopods and trilobites, with longer-lived genera more common than shorter-lived genera during the LPIA. However, only the total crinoid record significantly supports greater mean and median genus durations during the LPIA and it is not a strong signal (Table 4). The Mann-Whitney test of the individual crinoid clades revealed that they do not support the idea of longer mean genus durations during the LPIA. A study of the geographic extent of crinoids through the Paleozoic with a focus 
on the LPIA could provide a further test of the idea of lower probabilities of origination and extinction in marine invertebrates during the LPIA.

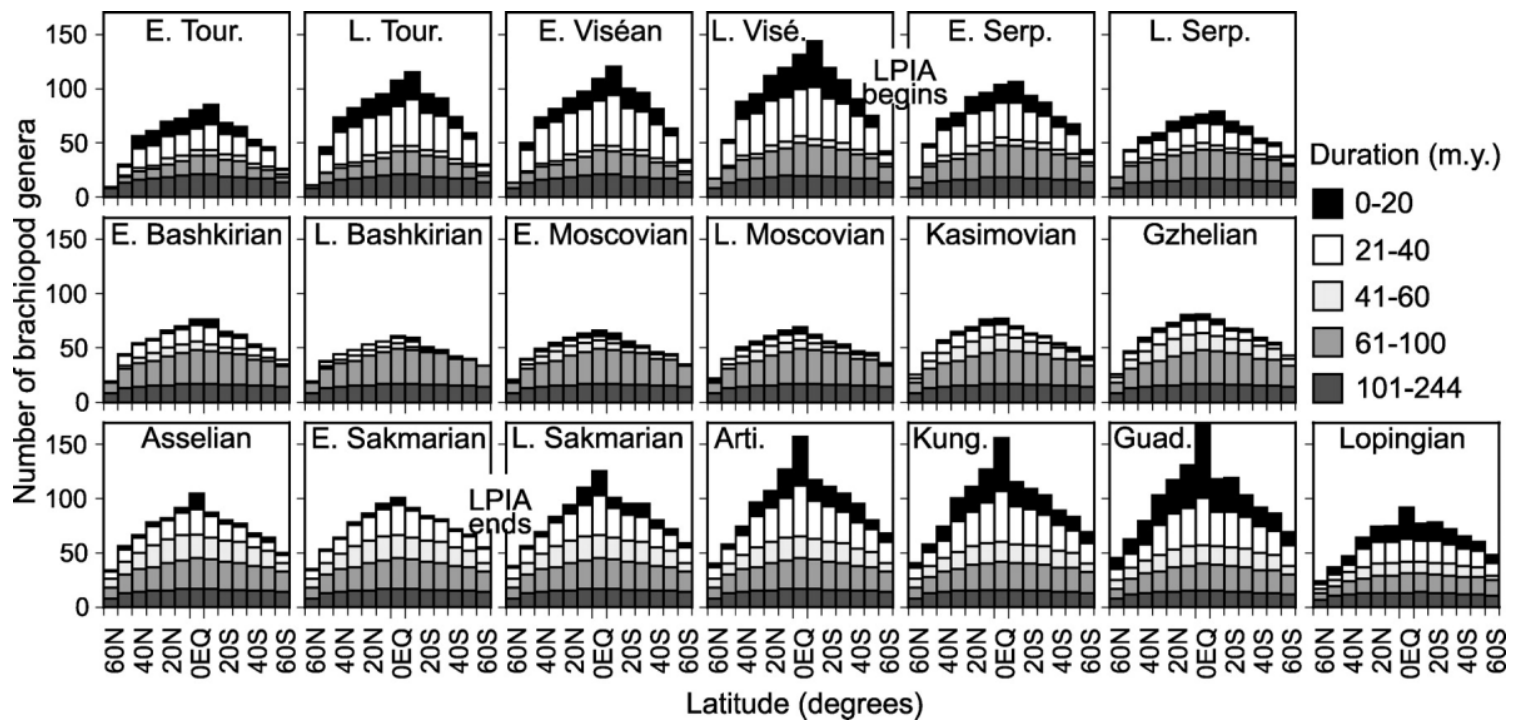

Figure 16 - Number of brachiopod genera sorted by stratigraphic duration (m.y.) at each latitude (10 increments) from Powell (2005).

\section{CONCLUSIONS}

Stanley and Powell (2003) hypothesized that rates of origination and extinction were decreased during the LPIA, in response to cooling environmental conditions. They predicted that evolutionary rates for individual taxonomic groups using updated databases of marine invertebrates would reflect the trend they observed based on Sepkoski's (2002) compendium of marine genera. Using a database of Paleozoic crinoids updated with current literature, the accuracy of their hypothesis was tested. Rates of crinoid origination and extinction during the LPIA and the surrounding intervals were calculated and compared. Potential sources of bias were identified and compensated for in the calculations, such as the lack of data due to taphonomic bias in the Latest Permian. 
Based on the results of the analyses performed for this study, rates of origination and extinction in all crinoid clades were decreased during the LPIA when compared with background extinction rates (Figure 9). Excluding the advanced cladids, diversity counts for all crinoid clades were decreased during the LPIA (Table 12). These findings support Stanley and Powell's hypothesis of reduced evolutionary rates in marine invertebrates during the LPIA due to environmental changes brought on by the series of glaciations. The advanced cladids are an exception to the predicted results, with diversity counts that are far higher during the LPIA then the surrounding background intervals.

While the advanced cladids behave in opposition to what was predicted, it may reflect on their unique adaptation to clastic influx in marine environments from the Alleghenian orogeny coincident with the LPIA. This exception does not refute Stanley and Powell's (2003) hypothesis. As carbonate dominated marine environments of the Mississippian gave way to siliciclastic dominated marine environments of the Pennsylvanian, advanced cladid diversity climbed. The unique adaptation of muscular arm articulations in the arms of advanced cladids allowed them to be successful during the LPIA where other crinoid clades were not. The advanced cladids' diversity during the LPIA is contrary to the predicted outcome, but rather than contradicting Stanley and Powell's (2003) hypothesis, the diversity trends in advanced cladids highlight global environmental change and its effects on specific clades of organisms. 


\section{REFERENCES CITED}

Alroy, J., 2014, Accurate and precise estimates of origination and extinction rates: Paleobiology, v. 40, p. 374-397.

Ausich, W.I., Baumiller, T.K., 1993, Taphonomic method for determining muscular articulations in fossil echinoderms: a test for the occurrence of muscles in Lower Mississippian cladid crinoids: PALAIOS, v. 8, p. 477-484.

Ausich, W.I., Kammer, T.W., 2013, Mississippian Crinoid Biodiversity, Biogeography and Macroevolution: Palaeontology, v. 56, p. 727-740.

Baumiller, T.K., 2008, Crinoid Ecological Morphology: Annual Review Earth Planetary Science, v. 36, p. 221-249.

Baumiller, T,K., Gahn, F.J., 2004, Testing predator-driven evolution with Paleozoic crinoid arm regeneration: Science, v. 305, p. 1453-1455.

Baumiller, T.K., 1993, Survivorship Analysis of Paleozoic Crinoidea: Effect of Filter Morphology on Evolutionary Rates: Paleobiology, v. 19, p. 304-321.

Bonelli, J.R., Patzkowsky, M.E., 2011, Taxonomic and ecologic persistence across the onset of the late Paleozoic ice age: evidence from the upper Mississippian (Chesterian series), Illinois Basin, United States: PALAIOS, v. 26, p. 5-17.

Brezinski, D.K., 1999, The Rise and Fall of Late Paleozoic Trilobites of the United States: Journal of Paleontology, v. 73, p. 164-175.

Charlton, T.R., Barber, A.J., Harris, R.A., Barkham, S.T., Bird, P.R., Archbold, N.W., Morris, N.J., Nicoll, R.S., Owen, H.G., Owens, R.M., Sorauf, J.E., Taylor, P.D., Webster, G.D., Whittaker, J.E., 2002, The Permian of Timor: stratigraphy, palaeontology and palaeogeography: Journal of Asian Earth Sciences, v. 20, p. 719-774.

Crampton, J.S., Beu, A.G., Cooper, R.A., Jones, C.M., Marshall, B., Maxwell, P.A., 2003, Estimating the Rock Volume Bias in Paleobiodiversity Studies: Science, v. 301, p. 358-360.

Ettonsohn, F.R., Greb, S.F., Chesnut, D.R., Jr., Harris, D.C., Mason, C.E., Eble, C.F., Howell, P.D., Watson, A.E., Johnson, W.K., 2002, Mississippian stratigraphy, depositional environments, and tectonic framework of the Central Appalachian Basin, eastern Kentucky, U.S.A., in Hills, L.V., Henderson, C.M., Bamber, E.W., eds., Carboniferous and Permian of the World: Canadian Society of Petroleum Geologists Memoir 19, p. 22-40. 
Fielding, C.R., Frank, T.D., Isbell, J.L., 2008, The late Paleozoic ice age-A review of current understanding and synthesis of global climate patterns, in Fielding, C.R., Frank, T.D., Isbell, J.L., eds., Resolving the Late Paleozoic Ice Age in Time and Space: Geological Society of America Special Paper 441, p. 343-354.

Foote, M., Miller, A.I., 2007, Principles of Paleontology: New York, W.H. Freeman and Company, $354 \mathrm{p}$.

Franco, D.R., Hinnov, L.A., Ernesto, M., 2012, Millenial-scale climate cycles in Permian-Carboniferous rhythmites: Permanent feature throughout geologic time?: Geology, v. 40, p. 19-22.

Gradstein, F.M., Ogg, J.G., Schmitz, M.D., Ogg, G.M., 2012, The Geologic Time Scale 2012, v. 1 and 2, 1579 p.

Groves, J.R., Lee, A., 2008, Accelerated rates of foraminiferal origination and extinction during the Late Paleozoic Ice Age: Journal of Foraminiferal Research, v. 38, p. 74-84.

Groves, J.R., Yue, W., 2009, Foraminiferal diversification during the late Paleozoic ice age: Paleobiology, v. 35, p. 367-392.

Guensburg, T.E., Sprinkle, J., 2001, Earliest crinoids: New evidence for the origin of the dominant Paleozoic echinoderms: Geology, v. 29, p. 131-134.

Holterhoff, P.F., 1997, Paleocommunity and Evolutionary Ecology of Paleozoic Crinoids: Paleontological Society Papers, v. 3, p. 69-106.

Hyde, W.T., Crowley, T.J., Tarasov, L., Peltier, W.R., 1999, The Pangean ice age: studies with a coupled climate-ice sheet model: Climate Dynamics, v. 15, p. 619629.

Kammer, T.W., Baumiller, T.K., Ausich, W.I., 1998, Evolutionary Significance of Differential Species Longevity in Osagean-Meramecian (Mississippian) Crinoid Clades: Paleobiology, v. 24, p. 155-176.

Kammer, T.W., Ausich, W.I., 2006, The "Age of Crinoids": A Mississippian Biodiversity Spike Coincident with Widespread Carbonate Ramps: Palaios, v. 21, p. 238-248.

Kammer, T.W., Matchen, D.L., 2008. Evidence for eustasy at the KinderhookianOsagean (Mississippian) boundary in the United States: Response to late Tournaisian glaciation?. Geological Society of America Special Papers, v. 441, pg. 261-274. 
Maynard, J.R., Leeder, M.R., 1992, On the periodicity and magnitude of Late Carboniferous glacio-eustatic sea-level changes: Journal of the Geological Society, London, v. 149, p. 303-311.

Montanez, I.P., Poulsen, C.J., 2013, The Late Paleozoic Ice Age: An Evolving Paradigm: Annual Review of Earth and Planetary Sciences, v. 41, p. 629-656.

Payne, J.L., Clapham, M.E., 2012, End-Permian Mass Extinction in the Oceans: An Ancient Analog for the Twenty-First Century?: Annual Review of Earth and Planetary Sciences, v. 40, p. 89-111.

Peters, S.E., Foote, M. 2002, Determinants of extinction in the fossil record: Nature, v. 416, p. 420-424.

Powell, M.G., 2005, Climatic basis for sluggish macroevolution during the late Paleozoic ice age: Geology, v. 33, p. 381-384.

Powell, M.G., 2007, Geographic range and genus longevity of late Paleozoic brachiopods: Paleobiology, v. 33, p. 530-546

Raup, D.M., 1976, Species diversity in the Phanerozoic: an interpretation: Paleobiology, v. 2, p. 289-297.

Rhenberg, E.C., Kammer, T.W., 2013, Camerate Crinoids from the Nunn Member (Tournaisian, Osagean) of the Lower Mississippian Lake Valley Formation, New Mexico: Journal of Paleontology, v. 87, p. 312-340.

Rhenberg, E.C., Ausich, W.I., Kammer, T.W., 2015, Generic concepts in the Actinocrinitidae Austin and Austin, 1842 (class Crinoidea) and evaluation of generic assignments of species: Journal of Paleontology, v. 89, p. 1-19.

Rygel, M.C., Fielding, C.R., Frank, T.D., Birgenheier, L.P., 2008, The Magnitude of Late Paleozoic Glacioeustatic Fluctuations: A Synthesis: Journal of Sedimentary Research, v. 78, pg. 500-511.

Sallan, L.C., Kammer, T.W., Ausich, W.I., Cook, L.A., 2011, Persistent predator-prey dynamics revealed by mass extinction: PNAS, v. 108, p. 8335-8338.

Shi, G.R., Waterhouse, J.B., 2010, Late Paleozoic global changes affecting high-latitude environments and biotas: An introduction: Elsevier, Palaeogeography, Palaeoclimatology, Palaeoecology, v. 298, p. 1-16.

Simms, M.J., Sevastopulo, G.D., 1993, The Origin of Articulate Crinoids: Paleontology, v. 36, p. 91-109. 
Sepkoski, J.J., 2002, A Compendium of Fossil Marine Animal Genera. Jablonski, D., and Foote, M. eds.: Bulletins of American Paleontology, No. 363, 560 p.

Smith, L.B., Jr., Read, J.F., 2000, Rapid onset of Late Paleozoic glaciation on Gondwana: evidence from Upper Mississippian strata of the Midcontinent, United States: Geology, v. 28, p. 279-282.

Sprinkle, J., Guensburg, T.E., 1997, Early radiation of echinoderms: Paleontological Society Papers, v. 3., p. 205-224.

Stanley, S.M., 1990, The general correlation between rate of speciation and rate of extinction: Fortuitous causal linkages, in Ross, R.M., Allmon, W.D., eds., Causes of evolution: A paleontological perspective: Chicago, University of Chicago Press, p. 103-127.

Stanley, S.M., Powell, M.G., 2003, Depressed rates of origination and extinction during the late Paleozoic ice age: A new state for the global marine ecosystem: Geology, v. 31, p. 877-880.

Sur, S., Soreghan, G.S., Soreghan, M.J., Yang, W., Saller, A.H., 2010, A record of glacial aridity and Milankovitch-scale fluctuations in atmospheric dust from the Pennsylvanian tropics: Journal of Sedimentary Research, v. 80, p. 1046-1067.

Twitchett, R.J., Oji, T., 2005, Early Triassic recovery of echinoderms: Elsevier, Palevol, v. 4, p. 531-542.

Waterhouse, J.B., Shi, G.R., 2010, Evolution in a cold climate: Palaeogeography, Palaeoclimatology, Palaeoecology, v. 298, pg. 17-30.

Webster, G.D., Donovan, S.K., 2015, Review and revision of the West Timor Permian Graphiocrinus species of Johannes Warner. Elsevier: Paleoworld, v. 24, p. 497522.

Webster, G.D., 2015, Paleozoic Crinoids, Coronates, and Hemistreptocrinoids, 1758 2012: Washington State University, <crinoids.azurewebsites.net>, 2/27/2015.

Webster, G.D., Becker, R.T., Maples, C.G., 2005, Biostratigraphy Paleoecology and Taxonomy of Devonian (Emsian and Famennian) Crinoids from Southeastern Morocco. Journal of Paleontology, v. 79, p. 1052-1071.

Webster, G.D., Jell, P.A., 1999, New Permian crinoids from Australia: Memoir of the Queensland Museum, v.43, p. 279-339.

Webster, G.D., 1998, Distortion in the stratigraphy and biostratigraphy of Timor, a historical review with an analysis of the crinoid and blastoid faunas: Proceedings of the Royal Society of Victoria, v. 110, p. 45-72. 


\section{APPENDIX: Database of Crinoid Genera}

First appearance dates, last appearance dates, durations, mean genus durations, median genus durations, and sample sizes of Paleozoic crinoid data. Crinoid data are separated by Order/clades and arranged alphabetically. The columns 'LPIA' and 'Background' represent genera that have stratigraphic ranges that fall within those intervals respectively. The Orders Sagenocrinida and Taxocrinida are combined into the 'flexible' clade. Values for total crinoids are also included.

Updated data by review of the literature by Kammer and Ausich, further updated by Kammer and Segessenman

Generic names in CAPS are new genera added to Sepkoski, 2002.

Stage names in CAPS are revised ranges from Kammer and Ausich, 2006.

Red, Blue, and Green text are updated/added in 2014/2015. Red text is Permian range revisions from

Webster, 2015. Blue text is non-Permian range revisions from Webster, 2015. Green text is revisions made from

Rhenberg et al., 2015.

\section{Cl. CRINOIDEA}

Or. DIPLOBATHRIDA

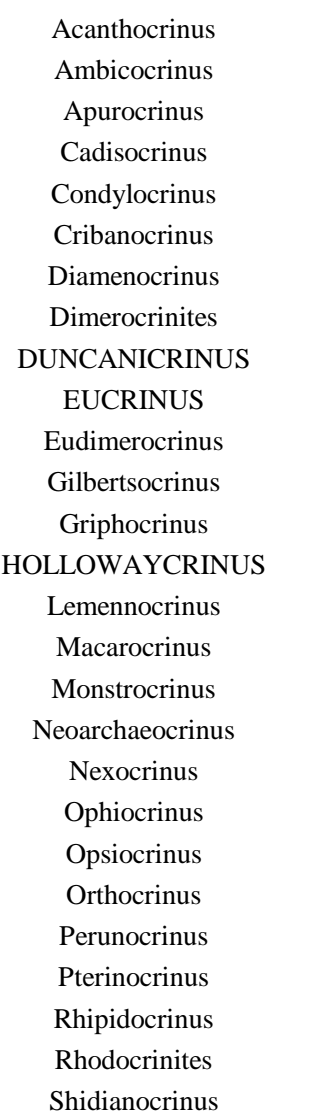

\begin{tabular}{|c|c|c|}
\hline (Emsi) & $\mathrm{D}$ & (Give) \\
\hline (Loch) & $\mathrm{D}$ & (Loch) \\
\hline (Emsi) & $\mathrm{D}$ & (Emsi) \\
\hline (Give) & $\mathrm{D}$ & (Give) \\
\hline (Eife) & $\mathrm{D}$ & (Eife) \\
\hline (Tour) & $\mathrm{C}$ & (Vise) \\
\hline (Loch) & $\mathrm{D}$ & (Emsi) \\
\hline (Ldov) & $\mathrm{D}$ & (Give) \\
\hline (Loch) & $\mathrm{D}$ & (Loch) \\
\hline (Wenl) & $\mathrm{D}$ & (Loch) \\
\hline (Ludl) & $\mathrm{D}$ & (Loch) \\
\hline (Give) & $\mathrm{C}$ & (Vise) \\
\hline (Eife) & $\mathrm{D}$ & (Give) \\
\hline (Loch) & $\mathrm{D}$ & (Loch) \\
\hline (Eife) & $\mathrm{D}$ & (Eife) \\
\hline (Emsi) & $\mathrm{D}$ & (Emsi) \\
\hline (Emsi) & $\mathrm{D}$ & (Eife) \\
\hline (Cara) & $\mathrm{D}$ & (Prag) \\
\hline (Ldov) & $\mathrm{D}$ & (Loch) \\
\hline (Loch) & $\mathrm{D}$ & (Emsi) \\
\hline (Give) & $\mathrm{D}$ & (Give) \\
\hline (Prag) & $\mathrm{D}$ & (Eife) \\
\hline (Prag) & $\mathrm{D}$ & (Emsi) \\
\hline (Emsi) & $\mathrm{D}$ & (Fras) \\
\hline (Eife) & $\mathrm{D}$ & (Fame) \\
\hline (Prag) & $\mathrm{C}$ & (Serp) \\
\hline (Give) & D & (Give) \\
\hline
\end{tabular}

\begin{tabular}{|l|l|l|l|l|}
\hline \multicolumn{5}{|c|}{ (MA) } \\
\hline FAD & LAD & Duration & LPIA & Background \\
\hline
\end{tabular}

$\begin{array}{ccccc}407.6 & 382.7 & 24.9 & 0.0 & 24.9 \\ 419.2 & 410.8 & 8.4 & 0.0 & 8.4 \\ 407.6 & 393.3 & 14.3 & 0.0 & 14.3 \\ 387.7 & 382.7 & 5.0 & 0.0 & 5.0 \\ 393.3 & 387.7 & 5.6 & 0.0 & 5.6 \\ 358.9 & 330.9 & 28.0 & 0.0 & 28.0 \\ 419.2 & 393.3 & 25.9 & 0.0 & 25.9 \\ 443.8 & 382.7 & 61.1 & 0.0 & 61.1 \\ 419.2 & 410.8 & 8.4 & 0.0 & 8.4 \\ 433.4 & 410.8 & 22.6 & 0.0 & 22.6 \\ 427.4 & 410.8 & 16.6 & 0.0 & 16.6 \\ 387.7 & 330.9 & 56.8 & 0.0 & 56.8 \\ 393.3 & 382.7 & 10.6 & 0.0 & 10.6 \\ 419.2 & 410.8 & 8.4 & 0.0 & 8.4 \\ 393.3 & 387.7 & 5.6 & 0.0 & 5.6 \\ 407.6 & 393.3 & 14.3 & 0.0 & 14.3 \\ 407.6 & 387.7 & 19.9 & 0.0 & 19.9 \\ 460.9 & 407.6 & 53.3 & 0.0 & 53.3 \\ 443.8 & 410.8 & 33.0 & 0.0 & 33.0 \\ 419.2 & 393.3 & 25.9 & 0.0 & 25.9 \\ 387.7 & 382.7 & 5.0 & 0.0 & 5.0 \\ 410.8 & 387.7 & 23.1 & 0.0 & 23.1 \\ 410.8 & 393.3 & 17.5 & 0.0 & 17.5 \\ 407.6 & 372.2 & 35.4 & 0.0 & 35.4 \\ 393.3 & 358.9 & 34.4 & 0.0 & 34.4 \\ 410.8 & 323.2 & 87.6 & 87.6 & 87.6 \\ 387.7 & 382.7 & 5.0 & 0.0 & 5.0\end{array}$




\begin{tabular}{|c|c|c|c|c|c|c|c|c|c|}
\hline Sphaerotocrinus & $\mathrm{D}$ & (Loch) & $\mathrm{D}$ & (Loch) & 419.2 & 410.8 & 8.4 & 0.0 & 8.4 \\
\hline Spyridiocrinus & $\mathrm{D}$ & (Prag) & $\mathrm{D}$ & (Emsi) & 410.8 & 393.3 & 17.5 & 0.0 & 17.5 \\
\hline \multirow[t]{4}{*}{ Thylacocrinus } & $\mathrm{D}$ & (Prag) & $\mathrm{D}$ & (Give) & 410.8 & 382.7 & 28.1 & 0.0 & 28.1 \\
\hline & & & & & \multicolumn{2}{|c|}{ Average Duration: } & 23.7 & 87.6 & 23.7 \\
\hline & & & & & \multicolumn{2}{|r|}{ Median: } & 19.9 & 87.6 & 18.7 \\
\hline & & & & & \multicolumn{2}{|c|}{$\mathbf{N}($ Sample) } & 30 & 1 & 30 \\
\hline \multicolumn{10}{|c|}{ Or. MONOBATHRIDA } \\
\hline Aacocrinus & $\mathrm{C}$ & (Tour) & $\mathrm{C}$ & (Bash) & 358.9 & 315.2 & 43.7 & 43.7 & 43.7 \\
\hline Abactinocrinus & $\mathrm{D}$ & (Fame) & $\mathrm{C}$ & (Tour) & 372.2 & 346.7 & 25.5 & 0.0 & 25.5 \\
\hline Abatocrinus & $\mathrm{C}$ & (Tour) & $\mathrm{C}$ & (Vise) & 358.9 & 330.9 & 28.0 & 0.0 & 28.0 \\
\hline Acacocrinus & $\mathrm{S}$ & (Ldov) & $\mathrm{D}$ & (Give) & 443.8 & 382.7 & 61.1 & 0.0 & 61.1 \\
\hline Acrocrinus & $\mathrm{C}$ & (Vise) & $\mathrm{C}$ & (Serp) & 346.7 & 323.2 & 23.5 & 23.5 & 23.5 \\
\hline Actinocrinites & $\mathrm{C}$ & (Tour) & $\mathrm{P}$ & (Artin) & 358.9 & 279.3 & 79.6 & 79.6 & 79.6 \\
\hline ADELOCRINUS & $\mathrm{D}$ & (Fame) & $\mathrm{D}$ & (Fame) & 372.2 & 358.9 & 13.3 & 0.0 & 13.3 \\
\hline Agaricocrinus & $\mathrm{C}$ & (Tour) & $\mathrm{C}$ & (Vise) & 358.9 & 330.9 & 28.0 & 0.0 & 28.0 \\
\hline Agathocrinus & $\mathrm{D}$ & (Emsi) & $\mathrm{D}$ & (Fame) & 407.6 & 358.9 & 48.7 & 0.0 & 48.7 \\
\hline Alloprosallocrinus & $\mathrm{C}$ & (Vise) & $\mathrm{C}$ & (Vise) & 346.7 & 330.9 & 15.8 & 0.0 & 15.8 \\
\hline Amonohexacrinus & $\mathrm{D}$ & (Emsi) & $\mathrm{D}$ & (Emsi) & 407.6 & 393.3 & 14.3 & 0.0 & 14.3 \\
\hline Amphoracrinus & $\mathrm{C}$ & (Tour) & $\mathrm{C}$ & (Vise) & 358.9 & 330.9 & 28.0 & 0.0 & 28.0 \\
\hline Amphoracrocrinus & $\mathrm{C}$ & (Vise) & $\mathrm{C}$ & (Serp) & 346.7 & 323.2 & 23.5 & 23.5 & 23.5 \\
\hline Ancalocrinus & $\mathrm{C}$ & (Tour) & $\mathrm{C}$ & (Tour) & 358.9 & 346.7 & 12.2 & 0.0 & 12.2 \\
\hline Aorocrinus & $\mathrm{D}$ & (Give) & $\mathrm{C}$ & (Vise) & 387.7 & 330.9 & 56.8 & 0.0 & 56.8 \\
\hline Arthroacantha & $\mathrm{D}$ & (Emsi) & $\mathrm{D}$ & (Fras) & 407.6 & 372.2 & 35.4 & 0.0 & 35.4 \\
\hline Aryballocrinus & $\mathrm{C}$ & (Tour) & $\mathrm{C}$ & (Vise) & 358.9 & 330.9 & 28.0 & 0.0 & 28.0 \\
\hline Athabascacrinus & $\mathrm{D}$ & (Fame) & $\mathrm{C}$ & (Tour) & 372.2 & 346.7 & 25.5 & 0.0 & 25.5 \\
\hline AULINOCRINUS & $\mathrm{D}$ & (Prag) & $\mathrm{D}$ & (Prag) & 410.8 & 407.6 & 3.2 & 0.0 & 3.2 \\
\hline Auliskocrinus & $\mathrm{C}$ & (Vise) & $\mathrm{P}$ & (Word) & 346.7 & 265.1 & 81.6 & 81.6 & 81.6 \\
\hline Azygocrinus & $\mathrm{C}$ & (Tour) & $\mathrm{C}$ & (Tour) & 358.9 & 346.7 & 12.2 & 0.0 & 12.2 \\
\hline Batocrinus & $\mathrm{C}$ & (Vise) & $\mathrm{C}$ & (Vise) & 346.7 & 330.9 & 15.8 & 0.0 & 15.8 \\
\hline Beyrichocrinus & $\mathrm{D}$ & (Prag) & $\mathrm{D}$ & (Prag) & 410.8 & 407.6 & 3.2 & 0.0 & 3.2 \\
\hline Blairocrinus & $\mathrm{C}$ & (Tour) & $\mathrm{C}$ & (Tour) & 358.9 & 346.7 & 12.2 & 0.0 & 12.2 \\
\hline Bogotacrinus & $\mathrm{D}$ & (Emsi) & $\mathrm{D}$ & (Eife) & 407.6 & 387.7 & 19.9 & 0.0 & 19.9 \\
\hline Boliviacrinus & $\mathrm{D}$ & (Eife) & $\mathrm{D}$ & (Eife) & 393.3 & 387.7 & 5.6 & 0.0 & 5.6 \\
\hline Brahmacrinus & $\mathrm{C}$ & (Tour) & $\mathrm{C}$ & (Vise) & 358.9 & 330.9 & 28.0 & 0.0 & 28.0 \\
\hline Cactocrinus & $\mathrm{C}$ & (Tour) & $\mathrm{C}$ & (Tour) & 358.9 & 346.7 & 12.2 & 0.0 & 12.2 \\
\hline Calliocrinus & $\mathrm{S}$ & (Wenl) & $\mathrm{D}$ & (Emsi) & 433.4 & 393.3 & 40.1 & 0.0 & 40.1 \\
\hline Camarocrinus & $\mathrm{S}$ & (Prid) & $\mathrm{D}$ & (Loch) & 423 & 410.8 & 12.2 & 0.0 & 12.2 \\
\hline Camptocrinus & $\mathrm{C}$ & (Vise) & $\mathrm{P}$ & (Artin) & 346.7 & 279.3 & 67.4 & 67.4 & 67.4 \\
\hline Cantharocrinus & $\mathrm{D}$ & (Emsi) & $\mathrm{D}$ & (Fame) & 407.6 & 358.9 & 48.7 & 0.0 & 48.7 \\
\hline Carpocrinus & $S$ & (Ldov) & $\mathrm{D}$ & (Prag) & 443.8 & 407.6 & 36.2 & 0.0 & 36.2 \\
\hline Caucacrocrinus & $\mathrm{C}$ & (Step) & $\mathrm{C}$ & (Step) & 307 & 298.9 & 8.1 & 8.1 & 0.0 \\
\hline Centriocrinus & $\mathrm{D}$ & (Eife) & $\mathrm{D}$ & (Eife) & 393.3 & 387.7 & 5.6 & 0.0 & 5.6 \\
\hline Cerasmocrinus & $\mathrm{D}$ & (Fras) & $\mathrm{D}$ & (Fras) & 382.7 & 372.2 & 10.5 & 0.0 & 10.5 \\
\hline Chinacrinus & $\mathrm{D}$ & (Fame) & $\mathrm{D}$ & (Fame) & 372.2 & 358.9 & 13.3 & 0.0 & 13.3 \\
\hline Clarkeocrinus & $\mathrm{D}$ & (Eife) & $\mathrm{D}$ & (Give) & 393.3 & 382.7 & 10.6 & 0.0 & 10.6 \\
\hline Clematocrinus & $\mathrm{S}$ & (Ludl) & $\mathrm{D}$ & (Loch) & 427.4 & 410.8 & 16.6 & 0.0 & 16.6 \\
\hline Coelocrinus & $\mathrm{C}$ & (Tour) & $\mathrm{C}$ & (Tour) & 358.9 & 346.7 & 12.2 & 0.0 & 12.2 \\
\hline Comanthocrinus & $\mathrm{D}$ & (Eife) & $\mathrm{D}$ & (Give) & 393.3 & 382.7 & 10.6 & 0.0 & 10.6 \\
\hline Cordylocrinus & $\mathrm{S}$ & (Wenl) & $\mathrm{D}$ & (Loch) & 433.4 & 410.8 & 22.6 & 0.0 & 22.6 \\
\hline Corocrinus & $\mathrm{D}$ & (Emsi) & $\mathrm{D}$ & (Give) & 407.6 & 382.7 & 24.9 & 0.0 & 24.9 \\
\hline Craterocrinus & $\mathrm{D}$ & (Emsi) & $\mathrm{D}$ & (Eife) & 407.6 & 387.7 & 19.9 & 0.0 & 19.9 \\
\hline Ctenocrinus & $\mathrm{S}$ & (Wenl) & $\mathrm{D}$ & (Fras) & 433.4 & 372.2 & 61.2 & 0.0 & 61.2 \\
\hline Culicocrinus & $\mathrm{S}$ & (Wenl) & $\mathrm{D}$ & (Emsi) & 433.4 & 393.3 & 40.1 & 0.0 & 40.1 \\
\hline Cusacrinus & $\mathrm{C}$ & (Tour) & $\mathrm{C}$ & (Tour) & 358.9 & 346.7 & 12.2 & 0.0 & 12.2 \\
\hline
\end{tabular}




\begin{tabular}{|c|c|c|c|c|c|c|c|c|c|}
\hline Cytidocrinus & $\mathrm{C}$ & (Tour) & $\mathrm{C}$ & (Tour) & 358.9 & 346.7 & 12.2 & 0.0 & 12.2 \\
\hline Cyttarocrinus & $\mathrm{D}$ & (Emsi) & $\mathrm{D}$ & (Give) & 407.6 & 382.7 & 24.9 & 0.0 & 24.9 \\
\hline DENARIOACROCRINUS & $\mathrm{C}$ & (Bash) & $\mathrm{C}$ & (Bash) & 323.2 & 315.2 & 8.0 & 8.0 & 0.0 \\
\hline Dialutocrinus & $\mathrm{C}$ & (Tour) & $\mathrm{C}$ & (Tour) & 358.9 & 346.7 & 12.2 & 0.0 & 12.2 \\
\hline Dichocrinus & $\mathrm{C}$ & (Tour) & $\mathrm{P}$ & (Word) & 358.9 & 265.1 & 93.8 & 93.8 & 93.8 \\
\hline Dilatocrinus & $\mathrm{C}$ & (Tour) & $\mathrm{C}$ & (Tour) & 358.9 & 346.7 & 12.2 & 0.0 & 12.2 \\
\hline Dinacrocrinus & $\mathrm{C}$ & (Mosc) & $\mathrm{C}$ & (Step) & 315.2 & 298.9 & 16.3 & 16.3 & 0.0 \\
\hline Displodocrinus & $\mathrm{C}$ & (Tour) & $\mathrm{C}$ & (Tour) & 358.9 & 346.7 & 12.2 & 0.0 & 12.2 \\
\hline Dizygocrinus & $\mathrm{C}$ & (Tour) & $\mathrm{C}$ & (Vise) & 358.9 & 330.9 & 28.0 & 0.0 & 28.0 \\
\hline Dolatocrinus & $\mathrm{D}$ & (Loch) & $\mathrm{D}$ & (Give) & 419.2 & 382.7 & 36.5 & 0.0 & 36.5 \\
\hline Dorycrinus & $\mathrm{C}$ & (Tour) & $\mathrm{C}$ & (Vise) & 358.9 & 330.9 & 28.0 & 0.0 & 28.0 \\
\hline Ectocrinus & $\mathrm{C}$ & (Tour) & $\mathrm{C}$ & (Serp) & 358.9 & 323.2 & 35.7 & 35.7 & 35.7 \\
\hline Eretmocrinus & $\mathrm{C}$ & (Tour) & $\mathrm{C}$ & (Mosc) & 358.9 & 307 & 51.9 & 51.9 & 51.9 \\
\hline Erlangeracrocrinus & $\mathrm{C}$ & (Mosc) & $\mathrm{C}$ & (Mosc) & 315.2 & 307 & 8.2 & 8.2 & 0.0 \\
\hline Eucalyptocrinites & $\mathrm{S}$ & (Ldov) & $\mathrm{D}$ & (Eife) & 443.8 & 387.7 & 56.1 & 0.0 & 56.1 \\
\hline Eucladocrinus & $\mathrm{C}$ & (Tour) & $\mathrm{C}$ & (Vise) & 358.9 & 330.9 & 28.0 & 0.0 & 28.0 \\
\hline Eumorphocrinus & $\mathrm{C}$ & (Tour) & $\mathrm{C}$ & (Vise) & 358.9 & 330.9 & 28.0 & 0.0 & 28.0 \\
\hline Eutelecrinus & $\mathrm{P}$ & (Artin) & $\mathrm{P}$ & (Artin) & 290.1 & 279.3 & 10.8 & 0.0 & 10.8 \\
\hline Eutrochocrinus & $\mathrm{C}$ & (Tour) & $\mathrm{C}$ & (Vise) & 358.9 & 330.9 & 28.0 & 0.0 & 28.0 \\
\hline Exotikocrinus & $\mathrm{P}$ & (Artin) & $\mathrm{P}$ & (Artin) & 290.1 & 279.3 & 10.8 & 0.0 & 10.8 \\
\hline FRANKOCRINUS & $\mathrm{D}$ & (Loch) & $\mathrm{D}$ & (Loch) & 419.2 & 410.8 & 8.4 & 0.0 & 8.4 \\
\hline Gennaeocrinus & $\mathrm{D}$ & (Give) & $\mathrm{D}$ & (Fame) & 387.7 & 358.9 & 28.8 & 0.0 & 28.8 \\
\hline Glaphyrocrinus & $\mathrm{C}$ & (Tour) & $\mathrm{C}$ & (Vise) & 358.9 & 330.9 & 28.0 & 0.0 & 28.0 \\
\hline Globacrocrinus & $\mathrm{C}$ & (Bash) & $\mathrm{C}$ & (Mosc) & 323.2 & 307 & 16.2 & 16.2 & 0.0 \\
\hline Globocrinus & $\mathrm{C}$ & (Vise) & $\mathrm{C}$ & (Serp) & 346.7 & 323.2 & 23.5 & 23.5 & 23.5 \\
\hline Hadrocrinus & $\mathrm{D}$ & (Emsi) & $\mathrm{D}$ & (Eife) & 407.6 & 387.7 & 19.9 & 0.0 & 19.9 \\
\hline Hexaacrocrinus & $\mathrm{C}$ & (Mosc) & $\mathrm{C}$ & (Mosc) & 315.2 & 307 & 8.2 & 8.2 & 0.0 \\
\hline Hexacrinites & $\mathrm{S}$ & (Ludl) & $\mathrm{C}$ & (Tour) & 427.4 & 346.7 & 80.7 & 0.0 & 80.7 \\
\hline Himerocrinus & $\mathrm{D}$ & (Loch) & $\mathrm{D}$ & (Emsi) & 419.2 & 393.3 & 25.9 & 0.0 & 25.9 \\
\hline Hyrtanecrinus & $\mathrm{C}$ & (Vise) & $\mathrm{C}$ & (Serp) & 346.7 & 323.2 & 23.5 & 23.5 & 23.5 \\
\hline Iberocrinus & $\mathrm{C}$ & (Bash) & $\mathrm{C}$ & (Mosc) & 323.2 & 307 & 16.2 & 16.2 & 0.0 \\
\hline Ilmocrinus & $\mathrm{C}$ & (Vise) & $\mathrm{C}$ & (Serp) & 346.7 & 323.2 & 23.5 & 23.5 & 23.5 \\
\hline IOTACRINUS & $\mathrm{C}$ & (Tour) & $\mathrm{C}$ & (Tour) & 358.9 & 346.7 & 12.2 & 0.0 & 12.2 \\
\hline Ivanovaecrinus & $\mathrm{C}$ & (Mosc) & $\mathrm{C}$ & (Mosc) & 315.2 & 307 & 8.2 & 8.2 & 0.0 \\
\hline Lenneocrinus & $\mathrm{D}$ & (Emsi) & $\mathrm{D}$ & (Fras) & 407.6 & 372.2 & 35.4 & 0.0 & 35.4 \\
\hline Liomolgocrinus & $\mathrm{D}$ & (Loch) & $\mathrm{D}$ & (Loch) & 419.2 & 410.8 & 8.4 & 0.0 & 8.4 \\
\hline Macrocrinus & $\mathrm{C}$ & (Tour) & $\mathrm{C}$ & (Vise) & 358.9 & 330.9 & 28.0 & 0.0 & 28.0 \\
\hline Macrostylocrinus & $\mathrm{O}$ & (Ashg) & $\mathrm{D}$ & (Emsi) & 451.1 & 393.3 & 57.8 & 0.0 & 57.8 \\
\hline Maligneocrinus & $\mathrm{C}$ & (Tour) & $\mathrm{C}$ & (Tour) & 358.9 & 346.7 & 12.2 & 0.0 & 12.2 \\
\hline MANDELACRINUS & $\mathrm{D}$ & (Emsi) & $\mathrm{D}$ & (Emsi) & 407.6 & 393.3 & 14.3 & 0.0 & 14.3 \\
\hline Manillacrinus & $\mathrm{C}$ & (Tour) & $\mathrm{C}$ & (Tour) & 358.9 & 346.7 & 12.2 & 0.0 & 12.2 \\
\hline Marhoumacrinus & $\mathrm{S}$ & (Prid) & $\mathrm{D}$ & (Loch) & 423 & 410.8 & 12.2 & 0.0 & 12.2 \\
\hline Marsupiocrinus & $S$ & (Wenl) & $\mathrm{D}$ & (Loch) & 433.4 & 410.8 & 22.6 & 0.0 & 22.6 \\
\hline Megaliocrinus & $\mathrm{C}$ & (Bash) & $\mathrm{C}$ & (Mosc) & 323.2 & 307 & 16.2 & 16.2 & 0.0 \\
\hline Megistocrinus & $\mathrm{D}$ & (Emsi) & $\mathrm{C}$ & (Tour) & 407.6 & 346.7 & 60.9 & 0.0 & 60.9 \\
\hline Melocrinites & $\mathrm{S}$ & (Wenl) & $\mathrm{C}$ & (Vise) & 433.4 & 330.9 & 102.5 & 0.0 & 102.5 \\
\hline Metacrocrinus & $\mathrm{C}$ & (Mosc) & $\mathrm{C}$ & (Mosc) & 315.2 & 307 & 8.2 & 8.2 & 0.0 \\
\hline Metaeutelecrinus & $\mathrm{P}$ & (Artin) & $\mathrm{P}$ & (Artin) & 290.1 & 279.3 & 10.8 & 0.0 & 10.8 \\
\hline Neocamptocrinus & $\mathrm{P}$ & (Sakm) & $\mathrm{P}$ & (Wuchia) & 295.5 & 254.2 & 41.3 & 41.3 & 41.3 \\
\hline Neodichocrinus & $\mathrm{P}$ & (Artin) & $\mathrm{P}$ & (Artin) & 290.1 & 279.3 & 10.8 & 0.0 & 10.8 \\
\hline Neoplatycrinus & $\mathrm{P}$ & (Sakm) & $\mathrm{P}$ & (Artin) & 295.5 & 279.3 & 16.2 & 16.2 & 16.2 \\
\hline Nunnacrinus & $\mathrm{C}$ & (Tour) & $\mathrm{C}$ & (Serp) & 358.9 & 323.2 & 35.7 & 35.7 & 35.7 \\
\hline Oehlerticrinus & $\mathrm{D}$ & (Loch) & $\mathrm{D}$ & (Eife) & 419.2 & 387.7 & 31.5 & 0.0 & 31.5 \\
\hline Oenochoacrinus & $\mathrm{D}$ & (Emsi) & $\mathrm{C}$ & (Tour) & 407.6 & 346.7 & 60.9 & 0.0 & 60.9 \\
\hline
\end{tabular}




\begin{tabular}{|c|c|c|c|c|c|c|c|c|c|}
\hline Pandanocrinus & $\mathrm{D}$ & (Prag) & $\mathrm{D}$ & (Prag) & 410.8 & 407.6 & 3.2 & 0.0 & 3.2 \\
\hline Paracrocrinus & $\mathrm{C}$ & (Mosc) & $\mathrm{C}$ & (Mosc) & 315.2 & 307 & 8.2 & 8.2 & 0.0 \\
\hline Paradichocrinus & $\mathrm{C}$ & (Tour) & $\mathrm{C}$ & (Vise) & 358.9 & 330.9 & 28.0 & 0.0 & 28.0 \\
\hline Paraeutelecrinus & $\mathrm{P}$ & (Artin) & $\mathrm{P}$ & (Artin) & 290.1 & 279.3 & 10.8 & 0.0 & 10.8 \\
\hline Paragaricocrinus & $\mathrm{P}$ & (Word) & $\mathrm{P}$ & (Word) & 268.8 & 265.1 & 3.7 & 0.0 & 3.7 \\
\hline Parahexacrinus & $\mathrm{D}$ & (Loch) & $\mathrm{D}$ & (Loch) & 419.2 & 410.8 & 8.4 & 0.0 & 8.4 \\
\hline Paramegaliocrinus & $\mathrm{C}$ & (Mosc) & $\mathrm{C}$ & (Mosc) & 315.2 & 307 & 8.2 & 8.2 & 0.0 \\
\hline Paratalarocrinus & $\mathrm{C}$ & (Serp) & $\mathrm{C}$ & (Serp) & 330.9 & 323.2 & 7.7 & 7.7 & 0.0 \\
\hline Periechocrinus & $\mathrm{S}$ & (Wenl) & $\mathrm{D}$ & (Give) & 433.4 & 382.7 & 50.7 & 0.0 & 50.7 \\
\hline Physetocrinus & $\mathrm{D}$ & (Fame) & $\mathrm{C}$ & (Bash) & 372.2 & 315.2 & 57.0 & 57.0 & 57.0 \\
\hline Pimlicocrinus & $\mathrm{C}$ & (Tour) & $\mathrm{C}$ & (Bash) & 358.9 & 315.2 & 43.7 & 43.7 & 43.7 \\
\hline Pithocrinus & $\mathrm{D}$ & (Emsi) & $\mathrm{D}$ & (Give) & 407.6 & 382.7 & 24.9 & 0.0 & 24.9 \\
\hline Planacrocrinus & $\mathrm{C}$ & (Bash) & $\mathrm{C}$ & (Step) & 323.2 & 298.9 & 24.3 & 24.3 & 0.0 \\
\hline Platyacrocrinus & $\mathrm{C}$ & (Bash) & $\mathrm{C}$ & (Bash) & 323.2 & 315.2 & 8.0 & 8.0 & 0.0 \\
\hline Platycrinites & $\mathrm{D}$ & (Eife) & $\mathrm{P}$ & (Guad-u) & 393.3 & 259.8 & 133.5 & 133.5 & 133.5 \\
\hline Platyhexacrinus & $\mathrm{D}$ & (Emsi) & $\mathrm{D}$ & (Eife) & 407.6 & 387.7 & 19.9 & 0.0 & 19.9 \\
\hline Plemnocrinus & $\mathrm{C}$ & (Tour) & $\mathrm{C}$ & (Tour) & 358.9 & 346.7 & 12.2 & 0.0 & 12.2 \\
\hline Plesiocrinus & $\mathrm{P}$ & (Artin) & $\mathrm{P}$ & (Artin) & 290.1 & 279.3 & 10.8 & 0.0 & 10.8 \\
\hline Pleurocrinus & $\mathrm{C}$ & (Tour) & $\mathrm{P}$ & (Guad-u) & 358.9 & 259.8 & 99.1 & 99.1 & 99.1 \\
\hline Pradocrinus & $\mathrm{D}$ & (Emsi) & $\mathrm{D}$ & (Emsi) & 407.6 & 393.3 & 14.3 & 0.0 & 14.3 \\
\hline Protacrocrinus & $\mathrm{C}$ & (Tour) & $\mathrm{C}$ & (Tour) & 358.9 & 346.7 & 12.2 & 0.0 & 12.2 \\
\hline Pterotocrinus & $\mathrm{C}$ & (Vise) & $\mathrm{C}$ & (Serp) & 346.7 & 323.2 & 23.5 & 23.5 & 23.5 \\
\hline Pyxidocrinus & $\mathrm{D}$ & (Emsi) & $\mathrm{D}$ & (Give) & 407.6 & 382.7 & 24.9 & 0.0 & 24.9 \\
\hline Sampsonocrinus & $\mathrm{C}$ & (Tour) & $\mathrm{C}$ & (Bash) & 358.9 & 315.2 & 43.7 & 43.7 & 43.7 \\
\hline Scyphocrinites & $\mathrm{S}$ & (Wenl) & $\mathrm{D}$ & (Loch) & 433.4 & 410.8 & 22.6 & 0.0 & 22.6 \\
\hline Shimantocrinus & $\mathrm{D}$ & (Prag) & $\mathrm{D}$ & (Prag) & 410.8 & 407.6 & 3.2 & 0.0 & 3.2 \\
\hline Springeracrocrinus & $\mathrm{C}$ & (Tour) & $\mathrm{C}$ & (Mosc) & 358.9 & 307 & 51.9 & 51.9 & 51.9 \\
\hline Stamnocrinus & $\mathrm{D}$ & (Emsi) & $\mathrm{D}$ & (Give) & 407.6 & 382.7 & 24.9 & 0.0 & 24.9 \\
\hline Steganocrinus & $\mathrm{C}$ & (Tour) & $\mathrm{C}$ & (Tour) & 358.9 & 346.7 & 12.2 & 0.0 & 12.2 \\
\hline Stomiocrinus & $\mathrm{C}$ & (Tour) & $\mathrm{P}$ & (Artin) & 358.9 & 279.3 & 79.6 & 79.6 & 79.6 \\
\hline Strimplecrinus & $\mathrm{D}$ & (Fame) & $\mathrm{C}$ & (Serp) & 372.2 & 323.2 & 49.0 & 49.0 & 49.0 \\
\hline Strotocrinus & $\mathrm{C}$ & (Tour) & $\mathrm{C}$ & (Tour) & 358.9 & 346.7 & 12.2 & 0.0 & 12.2 \\
\hline Struszocrinus & $\mathrm{D}$ & (Prag) & $\mathrm{D}$ & (Prag) & 410.8 & 407.6 & 3.2 & 0.0 & 3.2 \\
\hline Sunwaptacrinus & $\mathrm{C}$ & (Tour) & $\mathrm{C}$ & (Tour) & 358.9 & 346.7 & 12.2 & 0.0 & 12.2 \\
\hline Talarocrinus & $\mathrm{C}$ & (Vise) & $\mathrm{C}$ & (Serp) & 346.7 & 323.2 & 23.5 & 23.5 & 23.5 \\
\hline Tarantocrinus & $\mathrm{C}$ & (Tour) & $\mathrm{C}$ & (Tour) & 358.9 & 346.7 & 12.2 & 0.0 & 12.2 \\
\hline Technocrinus & $\mathrm{S}$ & (Ludl) & $\mathrm{D}$ & (Prag) & 427.4 & 407.6 & 19.8 & 0.0 & 19.8 \\
\hline Teleiocrinus & $\mathrm{C}$ & (Tour) & $\mathrm{C}$ & (Tour) & 358.9 & 346.7 & 12.2 & 0.0 & 12.2 \\
\hline Thallocrinus & $\mathrm{D}$ & (Emsi) & $\mathrm{D}$ & (Emsi) & 407.6 & 393.3 & 14.3 & 0.0 & 14.3 \\
\hline Thamnocrinus & $\mathrm{D}$ & (Give) & $\mathrm{D}$ & (Give) & 387.7 & 382.7 & 5.0 & 0.0 & 5.0 \\
\hline THINOCRINUS & $\mathrm{C}$ & (Tour) & $\mathrm{P}$ & (Artin) & 358.9 & 279.3 & 79.6 & 79.6 & 79.6 \\
\hline Timocrinus & D & (Emsi) & $\mathrm{D}$ & (Emsi) & 407.6 & 393.3 & 14.3 & 0.0 & 14.3 \\
\hline Timorechinus & $\mathrm{P}$ & (Artin) & $\mathrm{P}$ & (Artin) & 290.1 & 279.3 & 10.8 & 0.0 & 10.8 \\
\hline Timorocidaris & $\mathrm{P}$ & (Artin) & $\mathrm{P}$ & (Artin) & 290.1 & 279.3 & 10.8 & 0.0 & 10.8 \\
\hline Trichotocrinus & $\mathrm{D}$ & (Fras) & $\mathrm{D}$ & (Fras) & 382.7 & 372.2 & 10.5 & 0.0 & 10.5 \\
\hline Trybliocrinus & $\mathrm{D}$ & (Prag) & $\mathrm{D}$ & (Eife) & 410.8 & 387.7 & 23.1 & 0.0 & 23.1 \\
\hline Tunisiacrinus & $\mathrm{P}$ & (Word) & $\mathrm{P}$ & (Word) & 268.8 & 265.1 & 3.7 & 0.0 & 3.7 \\
\hline Uperocrinus & $\mathrm{D}$ & (Fame) & $\mathrm{C}$ & (Vise) & 372.2 & 330.9 & 41.3 & 0.0 & 41.3 \\
\hline WACRINUS & $\mathrm{D}$ & (Fame) & $\mathrm{D}$ & (Fame) & 372.2 & 358.9 & 13.3 & 0.0 & 13.3 \\
\hline Wannerocrinus & $\mathrm{P}$ & (Artin) & $\mathrm{P}$ & (Artin) & 290.1 & 279.3 & 10.8 & 0.0 & 10.8 \\
\hline \multirow[t]{3}{*}{ Xenocrinus } & $\mathrm{O}$ & (Ashg) & $\mathrm{O}$ & (Ashg) & 451.1 & 443.8 & 7.3 & 0.0 & 7.3 \\
\hline & & & & & \multirow[t]{2}{*}{ Average } & Duration: & 26.2 & 37.0 & 27.8 \\
\hline & & & & & & Median: & 19.9 & 23.5 & 22.6 \\
\hline
\end{tabular}




\section{Or. DISPARIDA}

\begin{tabular}{|c|c|c|c|c|c|c|c|c|c|}
\hline Allagecrinus & $\mathrm{D}$ & (Fame) & $\mathrm{C}$ & (Serp) & 372.2 & 323.2 & 49.0 & 49.0 & 49.0 \\
\hline Allocatillocrinus & $\mathrm{C}$ & (Vise) & $\mathrm{P}$ & (Artin) & 346.7 & 279.3 & 67.4 & 67.4 & 67.4 \\
\hline Anamesocrinus & $\mathrm{D}$ & (Give) & $\mathrm{D}$ & (Fame) & 387.7 & 358.9 & 28.8 & 0.0 & 28.8 \\
\hline Aureocrinus & $\mathrm{D}$ & (Prag) & $\mathrm{D}$ & (Prag) & 410.8 & 407.6 & 3.2 & 0.0 & 3.2 \\
\hline Belemnocrinus & $\mathrm{C}$ & (Tour) & $\mathrm{C}$ & (Vise) & 358.9 & 330.9 & 28.0 & 0.0 & 28.0 \\
\hline BELSKAYACRINUS & $\mathrm{C}$ & (Mosc) & $\mathrm{C}$ & (Mosc) & 315.2 & 307 & 8.2 & 8.2 & 0.0 \\
\hline Brachiocrinus & $\mathrm{D}$ & (Loch) & $\mathrm{D}$ & (Loch) & 419.2 & 410.8 & 8.4 & 0.0 & 8.4 \\
\hline Calycanthocrinus & $\mathrm{D}$ & (Emsi) & $\mathrm{D}$ & (Fame) & 407.6 & 358.9 & 48.7 & 0.0 & 48.7 \\
\hline Catillocrinus & $\mathrm{C}$ & (Tour) & $\mathrm{C}$ & (Bash) & 358.9 & 315.2 & 43.7 & 43.7 & 43.7 \\
\hline Cunctocrinus & $\mathrm{D}$ & (Give) & $\mathrm{D}$ & (Give) & 387.7 & 382.7 & 5.0 & 0.0 & 5.0 \\
\hline DARRAGHCRINUS & $\mathrm{D}$ & (Loch) & $\mathrm{D}$ & (Loch) & 419.2 & 410.8 & 8.4 & 0.0 & 8.4 \\
\hline Desmacriocrinus & $\mathrm{D}$ & (Fame) & $\mathrm{C}$ & (Tour) & 372.2 & 346.7 & 25.5 & 0.0 & 25.5 \\
\hline Dolerocrinus & $\mathrm{D}$ & (Eife) & $\mathrm{D}$ & (Eife) & 393.3 & 387.7 & 5.6 & 0.0 & 5.6 \\
\hline Eohalysiocrinus & $\mathrm{S}$ & (Wenl) & $\mathrm{D}$ & (Eife) & 433.4 & 387.7 & 45.7 & 0.0 & 45.7 \\
\hline Eopilidiocrinus & $\mathrm{P}$ & (Artin) & $\mathrm{P}$ & (Artin) & 290.1 & 279.3 & 10.8 & 0.0 & 10.8 \\
\hline Epihalysiocrinus & $\mathrm{C}$ & (Bash) & $\mathrm{P}$ & (Artin) & 323.2 & 279.3 & 43.9 & 43.9 & 43.9 \\
\hline Espanocrinus & $\mathrm{D}$ & (Emsi) & $\mathrm{D}$ & (Emsi) & 407.6 & 393.3 & 14.3 & 0.0 & 14.3 \\
\hline Eucatillocrinus & $\mathrm{C}$ & (Vise) & $\mathrm{C}$ & (Vise) & 346.7 & 330.9 & 15.8 & 0.0 & 15.8 \\
\hline Glaukosocrinus & $\mathrm{C}$ & (Mosc) & $\mathrm{P}$ & (Artin) & 315.2 & 279.3 & 35.9 & 35.9 & 35.9 \\
\hline Gongrocrinus & $\mathrm{C}$ & (Bash) & $\mathrm{C}$ & (Bash) & 323.2 & 315.2 & 8.0 & 8.0 & 0.0 \\
\hline Halysiocrinus & $\mathrm{D}$ & (Prag) & $\mathrm{C}$ & (Vise) & 410.8 & 330.9 & 79.9 & 0.0 & 79.9 \\
\hline Haplocrinites & $\mathrm{S}$ & (Ludl) & $\mathrm{C}$ & (Tour) & 427.4 & 346.7 & 80.7 & 0.0 & 80.7 \\
\hline Heracrinus & $\mathrm{D}$ & (Emsi) & $\mathrm{D}$ & (Emsi) & 407.6 & 393.3 & 14.3 & 0.0 & 14.3 \\
\hline Holynocrinus & $\mathrm{D}$ & (Emsi) & $\mathrm{D}$ & (Emsi) & 407.6 & 393.3 & 14.3 & 0.0 & 14.3 \\
\hline Isocatillocrinus & $\mathrm{P}$ & (Artin) & $\mathrm{P}$ & (Artin) & 290.1 & 279.3 & 10.8 & 0.0 & 10.8 \\
\hline Jaekelicrinus & $\mathrm{D}$ & (Fras) & $\mathrm{D}$ & (Fame) & 382.7 & 358.9 & 23.8 & 0.0 & 23.8 \\
\hline Junocrinus & $\mathrm{D}$ & (Prag) & $\mathrm{D}$ & (Prag) & 410.8 & 407.6 & 3.2 & 0.0 & 3.2 \\
\hline \multicolumn{10}{|l|}{ Kallimorphocrinus } \\
\hline (+ Isoallagecrinus) & $\mathrm{C}$ & (Vise) & $\mathrm{P}$ & (Wolf) & 346.7 & 279.3 & 67.4 & 67.4 & 67.4 \\
\hline Kolvacrinus & $\mathrm{P}$ & (Artin) & $\mathrm{P}$ & (Artin) & 290.1 & 279.3 & 10.8 & 0.0 & 10.8 \\
\hline KROPPOCRINUS & $\mathrm{D}$ & (Loch) & $\mathrm{D}$ & (Loch) & 419.2 & 410.8 & 8.4 & 0.0 & 8.4 \\
\hline Litocrinus & $\mathrm{C}$ & (Tour) & $\mathrm{P}$ & (Artin) & 358.9 & 279.3 & 79.6 & 79.6 & 79.6 \\
\hline Metacatillocrinus & $\mathrm{C}$ & (Mosc) & $\mathrm{C}$ & (Mosc) & 315.2 & 307 & 8.2 & 8.2 & 0.0 \\
\hline Metallagecrinus & $\mathrm{P}$ & (Artin) & $\mathrm{P}$ & (Word) & 290.1 & 265.1 & 25.0 & 0.0 & 25.0 \\
\hline Minicrinus & $\mathrm{D}$ & (Eife) & $\mathrm{D}$ & (Eife) & 393.3 & 387.7 & 5.6 & 0.0 & 5.6 \\
\hline Mycocrinus & $\mathrm{D}$ & (Eife) & $\mathrm{D}$ & (Eife) & 393.3 & 387.7 & 5.6 & 0.0 & 5.6 \\
\hline Myelodactylus & $\mathrm{S}$ & (Ldov) & $\mathrm{D}$ & (Emsi) & 443.8 & 393.3 & 50.5 & 0.0 & 50.5 \\
\hline Neocatillocrinus & $\mathrm{P}$ & (Artin) & $\mathrm{P}$ & (Artin) & 290.1 & 279.3 & 10.8 & 0.0 & 10.8 \\
\hline Notiocatillocrinus & $\mathrm{P}$ & (Sakm) & $\mathrm{P}$ & (Artin) & 295.5 & 279.3 & 16.2 & 16.2 & 16.2 \\
\hline Paracatillocrinus & $\mathrm{P}$ & (Artin) & $\mathrm{P}$ & (Artin) & 290.1 & 279.3 & 10.8 & 0.0 & 10.8 \\
\hline Paradoxocrinus & $\mathrm{P}$ & (Artin) & $\mathrm{P}$ & (Artin) & 290.1 & 279.3 & 10.8 & 0.0 & 10.8 \\
\hline Parapisocrinus & $\mathrm{S}$ & (Wenl) & $\mathrm{D}$ & (Emsi) & 433.4 & 393.3 & 40.1 & 0.0 & 40.1 \\
\hline Phimocrinus & $\mathrm{S}$ & (Ludl) & $\mathrm{D}$ & (Eife) & 427.4 & 387.7 & 39.7 & 0.0 & 39.7 \\
\hline Pisocrinus & $\mathrm{S}$ & (Ldov) & $\mathrm{D}$ & (Eife) & 443.8 & 387.7 & 56.1 & 0.0 & 56.1 \\
\hline PLAYFORDICRINUS & $\mathrm{D}$ & (Fame) & $\mathrm{D}$ & (Fame) & 372.2 & 358.9 & 13.3 & 0.0 & 13.3 \\
\hline Pygmaeocrinus & $\mathrm{D}$ & (Prag) & $\mathrm{D}$ & (Emsi) & 410.8 & 393.3 & 17.5 & 0.0 & 17.5 \\
\hline Quiniocrinus & $\mathrm{D}$ & (Eife) & $\mathrm{D}$ & (Eife) & 393.3 & 387.7 & 5.6 & 0.0 & 5.6 \\
\hline Ramacrinus & $\mathrm{D}$ & (Prag) & $\mathrm{D}$ & (Emsi) & 410.8 & 393.3 & 17.5 & 0.0 & 17.5 \\
\hline Resetocrinus & $\mathrm{D}$ & (Emsi) & $\mathrm{D}$ & (Emsi) & 407.6 & 393.3 & 14.3 & 0.0 & 14.3 \\
\hline Senariocrinus & $\mathrm{D}$ & (Emsi) & $\mathrm{D}$ & (Emsi) & 407.6 & 393.3 & 14.3 & 0.0 & 14.3 \\
\hline Stereobrachicrinus & $\mathrm{C}$ & (Bash) & $\mathrm{C}$ & (Bash) & 323.2 & 315.2 & 8.0 & 8.0 & 0.0 \\
\hline
\end{tabular}




\begin{tabular}{|c|c|c|}
\hline Storthingocrinus & $\mathrm{D}$ & (Eife) \\
\hline Stylocrinus & $S$ & (Ludl) \\
\hline Synbathocrinus & $\mathrm{D}$ & (Emsi) \\
\hline Synchirocrinus & $\mathrm{S}$ & (Ldov) \\
\hline Thaminocrinus & $\mathrm{C}$ & (Vise) \\
\hline Theloreus & $\mathrm{D}$ & (Loch) \\
\hline Tiaracrinus & $\mathrm{D}$ & (Loch) \\
\hline Triacrinus & $S$ & (Ludl) \\
\hline Trichocrinus & $S$ & (Ludl) \\
\hline Trophocrinus & $\mathrm{C}$ & (Tour) \\
\hline Ufacrinus & $\mathrm{P}$ & (Artin) \\
\hline Whiteocrinus & $\mathrm{C}$ & (Tour) \\
\hline Wrightocrinus & $\mathrm{P}$ & (Sakm) \\
\hline Xenocatillocrinus & $\mathrm{P}$ & (Artin) \\
\hline Xisoallogecrinus & $\mathrm{C}$ & (Mosc) \\
\hline
\end{tabular}

\section{Or. CLADIDA}

\section{PRIMITIVE CLADIDS}

\begin{tabular}{|c|c|c|c|c|c|c|c|c|c|}
\hline Abrachiocrinus & $\mathrm{C}$ & (Vise) & $\mathrm{P}$ & (Artin) & 346.7 & 279.3 & 67.4 & 67.4 & 67.4 \\
\hline Acariaiocrinus & $\mathrm{P}$ & (Artin) & $\mathrm{P}$ & (Artin) & 290.1 & 279.3 & 10.8 & 0.0 & 10.8 \\
\hline Achradocrinus & $\mathrm{D}$ & (Eife) & $\mathrm{D}$ & (Eife) & 393.3 & 387.7 & 5.6 & 0.0 & 5.6 \\
\hline Allosycocrinus & $\mathrm{P}$ & (Artin) & $\mathrm{P}$ & (Artin) & 290.1 & 279.3 & 10.8 & 0.0 & 10.8 \\
\hline Amphipsalidocrinus & $\mathrm{D}$ & (Give) & $\mathrm{P}$ & (Artin) & 387.7 & 279.3 & 108.4 & 108.4 & 108.4 \\
\hline Anaglyptocrinus & $\mathrm{P}$ & (Artin) & $\mathrm{P}$ & (Artin) & 290.1 & 279.3 & 10.8 & 0.0 & 10.8 \\
\hline Ancyrocrinus & $\mathrm{D}$ & (Prag) & $\mathrm{D}$ & (Give) & 410.8 & 382.7 & 28.1 & 0.0 & 28.1 \\
\hline Antihomocrinus & $\mathrm{S}$ & (Ludl) & $\mathrm{D}$ & (Emsi) & 427.4 & 393.3 & 34.1 & 0.0 & 34.1 \\
\hline Arachnocrinus & $\mathrm{D}$ & (Emsi) & $\mathrm{D}$ & (Eife) & 407.6 & 387.7 & 19.9 & 0.0 & 19.9 \\
\hline Asymmetrocrinus & $\mathrm{P}$ & (Artin) & $\mathrm{P}$ & (Artin) & 290.1 & 279.3 & 10.8 & 0.0 & 10.8 \\
\hline Atelestocrinus & $\mathrm{C}$ & (Tour) & $\mathrm{C}$ & (Tour) & 358.9 & 346.7 & 12.2 & 0.0 & 12.2 \\
\hline Atractocrinus & $\mathrm{D}$ & (Eife) & $\mathrm{D}$ & (Give) & 393.3 & 382.7 & 10.6 & 0.0 & 10.6 \\
\hline Atremacrinus & $\mathrm{P}$ & (Artin) & $\mathrm{P}$ & (Artin) & 290.1 & 279.3 & 10.8 & 0.0 & 10.8 \\
\hline Aulodesocrinus & $\mathrm{C}$ & (Vise) & $\mathrm{C}$ & (Vise) & 346.7 & 330.9 & 15.8 & 0.0 & 15.8 \\
\hline Bactrocrinites & $\mathrm{S}$ & (Ludl) & $\mathrm{D}$ & (Give) & 427.4 & 382.7 & 44.7 & 0.0 & 44.7 \\
\hline Barycrinus & $\mathrm{C}$ & (Tour) & $\mathrm{C}$ & (Vise) & 358.9 & 330.9 & 28.0 & 0.0 & 28.0 \\
\hline Belanskicrinus & $\mathrm{D}$ & (Fras) & $\mathrm{D}$ & (Fras) & 382.7 & 372.2 & 10.5 & 0.0 & 10.5 \\
\hline Bolbocrinus & $\mathrm{P}$ & (Artin) & $\mathrm{P}$ & (Artin) & 290.1 & 279.3 & 10.8 & 0.0 & 10.8 \\
\hline Botryocrinus & $S$ & (Wenl) & $\mathrm{D}$ & (Give) & 433.4 & 382.7 & 50.7 & 0.0 & 50.7 \\
\hline Briseocrinus & $\mathrm{D}$ & (Emsi) & $\mathrm{D}$ & (Emsi) & 407.6 & 393.3 & 14.3 & 0.0 & 14.3 \\
\hline Carlopsocrinus & $\mathrm{C}$ & (Vise) & $\mathrm{C}$ & (Vise) & 346.7 & 330.9 & 15.8 & 0.0 & 15.8 \\
\hline Ceratocrinus & $\mathrm{P}$ & (Artin) & $\mathrm{P}$ & (Artin) & 290.1 & 279.3 & 10.8 & 0.0 & 10.8 \\
\hline Cestocrinus & $\mathrm{C}$ & (Vise) & $\mathrm{C}$ & (Vise) & 346.7 & 330.9 & 15.8 & 0.0 & 15.8 \\
\hline Clistocrinus & D & (Give) & $\mathrm{P}$ & (Artin) & 387.7 & 279.3 & 108.4 & 108.4 & 108.4 \\
\hline Codiacrinus & $\mathrm{D}$ & (Loch) & $\mathrm{D}$ & (Fras) & 419.2 & 372.2 & 47.0 & 0.0 & 47.0 \\
\hline Coenocystis & $\mathrm{C}$ & (Mosc) & $\mathrm{P}$ & (Guad-u) & 315.2 & 259.8 & 55.4 & 55.4 & 55.4 \\
\hline Corynecrinus & $\mathrm{D}$ & (Emsi) & $\mathrm{D}$ & (Emsi) & 407.6 & 393.3 & 14.3 & 0.0 & 14.3 \\
\hline Costalocrinus & $\mathrm{D}$ & (Prag) & $\mathrm{C}$ & (Vise) & 410.8 & 330.9 & 79.9 & 0.0 & 79.9 \\
\hline Cradeocrinus & $\mathrm{D}$ & (Give) & $\mathrm{C}$ & (Tour) & 387.7 & 346.7 & 41.0 & 0.0 & 41.0 \\
\hline Cranocrinus & $\mathrm{C}$ & (Bash) & $\mathrm{P}$ & (Artin) & 323.2 & 279.3 & 43.9 & 43.9 & 43.9 \\
\hline Crotalocrinites & $\mathrm{S}$ & (Wenl) & $\mathrm{D}$ & (Loch) & 433.4 & 410.8 & 22.6 & 0.0 & 22.6 \\
\hline Cyathocrinites & $\mathrm{S}$ & (Wenl) & $\mathrm{P}$ & (Word) & 433.4 & 265.1 & 168.3 & 168.3 & 168.3 \\
\hline Cydonocrinus & $\mathrm{C}$ & (Vise) & $\mathrm{P}$ & (Artin) & 346.7 & 279.3 & 67.4 & 67.4 & 67.4 \\
\hline
\end{tabular}




\begin{tabular}{|c|c|c|c|c|c|c|c|c|c|}
\hline DECOROCRINUS & $\mathrm{D}$ & (Give) & $\mathrm{D}$ & (Give) & 387.7 & 382.7 & 5.0 & 0.0 & 5.0 \\
\hline Dendrocrinus & $\mathrm{O}$ & (Cara) & $\mathrm{D}$ & (Loch) & 460.9 & 410.8 & 50.1 & 0.0 & 50.1 \\
\hline Dichostreblocrinus & $\mathrm{C}$ & (Tour) & $\mathrm{P}$ & (Artin) & 358.9 & 279.3 & 79.6 & 79.6 & 79.6 \\
\hline Dictenocrinus & $S$ & (Wenl) & $\mathrm{D}$ & (Emsi) & 433.4 & 393.3 & 40.1 & 0.0 & 40.1 \\
\hline ECKIDOCRINUS & $\mathrm{D}$ & (Eife) & $\mathrm{D}$ & (Eife) & 393.3 & 387.7 & 5.6 & 0.0 & 5.6 \\
\hline Edapocrinus & $\mathrm{C}$ & (Vise) & $\mathrm{C}$ & (Vise) & 346.7 & 330.9 & 15.8 & 0.0 & 15.8 \\
\hline (Eife)locrinus & $\mathrm{D}$ & (Emsi) & $\mathrm{D}$ & (Eife) & 407.6 & 387.7 & 19.9 & 0.0 & 19.9 \\
\hline Embryocrinus & $\mathrm{P}$ & (Artin) & $\mathrm{P}$ & (Word) & 290.1 & 265.1 & 25.0 & 0.0 & 25.0 \\
\hline FIANNACRINUS & $\mathrm{C}$ & (Tour) & $\mathrm{C}$ & (Tour) & 358.9 & 346.7 & 12.2 & 0.0 & 12.2 \\
\hline Follicrinus & $\mathrm{D}$ & (Prag) & $\mathrm{D}$ & (Eife) & 410.8 & 387.7 & 23.1 & 0.0 & 23.1 \\
\hline Gasterocoma & $\mathrm{D}$ & (Prag) & $\mathrm{D}$ & (Give) & 410.8 & 382.7 & 28.1 & 0.0 & 28.1 \\
\hline Gastrocrinus & $\mathrm{D}$ & (Prag) & $\mathrm{D}$ & (Emsi) & 410.8 & 393.3 & 17.5 & 0.0 & 17.5 \\
\hline Gissocrinus & $S$ & (Wenl) & $\mathrm{D}$ & (Emsi) & 433.4 & 393.3 & 40.1 & 0.0 & 40.1 \\
\hline Goniocrinus & $\mathrm{D}$ & (Eife) & $\mathrm{C}$ & (Vise) & 393.3 & 330.9 & 62.4 & 0.0 & 62.4 \\
\hline Harrellicrinus & $\mathrm{P}$ & (Artin) & $\mathrm{P}$ & (Artin) & 290.1 & 279.3 & 10.8 & 0.0 & 10.8 \\
\hline HEBOHENOCRINUS & $\mathrm{C}$ & (Bash) & $\mathrm{C}$ & (Bash) & 323.2 & 315.2 & 8.0 & 8.0 & 0.0 \\
\hline Hemistreptacron & $\mathrm{P}$ & (Artin) & $\mathrm{P}$ & (Artin) & 290.1 & 279.3 & 10.8 & 0.0 & 10.8 \\
\hline HOLMESOCRINUS & $\mathrm{D}$ & (Loch) & $\mathrm{D}$ & (Loch) & 419.2 & 410.8 & 8.4 & 0.0 & 8.4 \\
\hline Hydroporocrinus & $\mathrm{P}$ & (Artin) & $\mathrm{P}$ & (Artin) & 290.1 & 279.3 & 10.8 & 0.0 & 10.8 \\
\hline Hypocrinus & $\mathrm{P}$ & (Asse) & $\mathrm{P}$ & (Artin) & 298.9 & 279.3 & 19.6 & 19.6 & 19.6 \\
\hline Idaeumocrinus & $\mathrm{D}$ & (Loch) & $\mathrm{D}$ & (Prag) & 419.2 & 407.6 & 11.6 & 0.0 & 11.6 \\
\hline Imitatocrinus & $\mathrm{D}$ & (Emsi) & $\mathrm{D}$ & (Emsi) & 407.6 & 393.3 & 14.3 & 0.0 & 14.3 \\
\hline Iteacrinus & $\mathrm{D}$ & (Emsi) & $\mathrm{D}$ & (Fras) & 407.6 & 372.2 & 35.4 & 0.0 & 35.4 \\
\hline Jahnocrinus & $\mathrm{D}$ & (Give) & $\mathrm{D}$ & (Give) & 387.7 & 382.7 & 5.0 & 0.0 & 5.0 \\
\hline Koivocrinus & $\mathrm{P}$ & (Sakm) & $\mathrm{P}$ & (Sakm) & 295.5 & 290.1 & 5.4 & 5.4 & 0.0 \\
\hline Kopficrinus & $\mathrm{D}$ & (Emsi) & $\mathrm{D}$ & (Emsi) & 407.6 & 393.3 & 14.3 & 0.0 & 14.3 \\
\hline KOPRIACRINUS & $\mathrm{C}$ & (Mosc) & $\mathrm{C}$ & (Mosc) & 315.2 & 307 & 8.2 & 8.2 & 0.0 \\
\hline Kooptoonocrinus & $\mathrm{S}$ & (Prid) & $\mathrm{D}$ & (Loch) & 423 & 410.8 & 12.2 & 0.0 & 12.2 \\
\hline Kophinocrinus & $\mathrm{D}$ & (Give) & $\mathrm{D}$ & (Give) & 387.7 & 382.7 & 5.0 & 0.0 & 5.0 \\
\hline Lageniocrinus & $\mathrm{C}$ & (Vise) & $\mathrm{P}$ & (Artin) & 346.7 & 279.3 & 67.4 & 67.4 & 67.4 \\
\hline Lampadosocrinus & $\mathrm{C}$ & (Tour) & $\mathrm{P}$ & (Sakm) & 358.9 & 290.1 & 68.8 & 68.8 & 68.8 \\
\hline Lasiocrinus & $\mathrm{D}$ & (Loch) & $\mathrm{C}$ & (Tour) & 419.2 & 346.7 & 72.5 & 0.0 & 72.5 \\
\hline Lecythiocrinus & $\mathrm{C}$ & (Bash) & $\mathrm{P}$ & (Artin) & 323.2 & 279.3 & 43.9 & 43.9 & 43.9 \\
\hline Lecythocrinus & $\mathrm{D}$ & (Eife) & $\mathrm{D}$ & (Give) & 393.3 & 382.7 & 10.6 & 0.0 & 10.6 \\
\hline Metasycocrinus & $\mathrm{P}$ & (Artin) & $\mathrm{P}$ & (Artin) & 290.1 & 279.3 & 10.8 & 0.0 & 10.8 \\
\hline Mictocrinus & $\mathrm{D}$ & (Emsi) & $\mathrm{D}$ & (Give) & 407.6 & 382.7 & 24.9 & 0.0 & 24.9 \\
\hline MONALDICRINUS & $\mathrm{D}$ & (Eife) & $\mathrm{D}$ & (Eife) & 393.3 & 387.7 & 5.6 & 0.0 & 5.6 \\
\hline Monobrachiocrinus & $\mathrm{P}$ & (Artin) & $\mathrm{P}$ & (Artin) & 290.1 & 279.3 & 10.8 & 0.0 & 10.8 \\
\hline Myrtillocrinus & $\mathrm{D}$ & (Emsi) & $\mathrm{D}$ & (Give) & 407.6 & 382.7 & 24.9 & 0.0 & 24.9 \\
\hline Nanocrinus & $\mathrm{D}$ & (Eife) & $\mathrm{D}$ & (Eife) & 393.3 & 387.7 & 5.6 & 0.0 & 5.6 \\
\hline Nassoviocrinus & $S$ & (Ludl) & $\mathrm{D}$ & (Give) & 427.4 & 382.7 & 44.7 & 0.0 & 44.7 \\
\hline Necopinocrinus & $\mathrm{P}$ & (Artin) & $\mathrm{P}$ & (Artin) & 290.1 & 279.3 & 10.8 & 0.0 & 10.8 \\
\hline NEERKOLOCRINUS & $\mathrm{C}$ & (Mosc) & $\mathrm{C}$ & (Mosc) & 315.2 & 307 & 8.2 & 8.2 & 0.0 \\
\hline Neolageniocrinus & $\mathrm{C}$ & (Vise) & $\mathrm{P}$ & (Artin) & 346.7 & 279.3 & 67.4 & 67.4 & 67.4 \\
\hline Nereocrinus & $\mathrm{P}$ & (Artin) & $\mathrm{P}$ & (Artin) & 290.1 & 279.3 & 10.8 & 0.0 & 10.8 \\
\hline Nuxocrinus & $\mathrm{D}$ & (Emsi) & $\mathrm{D}$ & (Give) & 407.6 & 382.7 & 24.9 & 0.0 & 24.9 \\
\hline Occiducrinus & $\mathrm{P}$ & (Artin) & $\mathrm{P}$ & (Artin) & 290.1 & 279.3 & 10.8 & 0.0 & 10.8 \\
\hline Oligobrachyocrinus & $\mathrm{P}$ & (Artin) & $\mathrm{P}$ & (Artin) & 290.1 & 279.3 & 10.8 & 0.0 & 10.8 \\
\hline OTHOZECRINUS & $\mathrm{D}$ & (Emsi) & $\mathrm{D}$ & (Emsi) & 407.6 & 393.3 & 14.3 & 0.0 & 14.3 \\
\hline Pagecrinus & $\mathrm{D}$ & (Emsi) & $\mathrm{D}$ & (Fras) & 407.6 & 372.2 & 35.4 & 0.0 & 35.4 \\
\hline Parabotryocrinus & $\mathrm{D}$ & (Fras) & $\mathrm{D}$ & (Fras) & 382.7 & 372.2 & 10.5 & 0.0 & 10.5 \\
\hline Paracydonocrinus & $\mathrm{P}$ & (Artin) & $\mathrm{P}$ & (Artin) & 290.1 & 279.3 & 10.8 & 0.0 & 10.8 \\
\hline Parapernerocrinus & $\mathrm{D}$ & (Emsi) & $\mathrm{D}$ & (Emsi) & 407.6 & 393.3 & 14.3 & 0.0 & 14.3 \\
\hline
\end{tabular}




\begin{tabular}{|c|c|c|c|c|c|c|c|c|c|}
\hline Parasycocrinus & $\mathrm{P}$ & (Artin) & $\mathrm{P}$ & (Artin) & 290.1 & 279.3 & 10.8 & 0.0 & 10.8 \\
\hline Parathetidicrinus & $\mathrm{P}$ & (Sakm) & $\mathrm{P}$ & (Sakm) & 295.5 & 290.1 & 5.4 & 5.4 & 0.0 \\
\hline Parisangulocrinus & $\mathrm{D}$ & (Loch) & $\mathrm{D}$ & (Emsi) & 419.2 & 393.3 & 25.9 & 0.0 & 25.9 \\
\hline Parisocrinus & $\mathrm{D}$ & (Eife) & $\mathrm{C}$ & (Vise) & 393.3 & 330.9 & 62.4 & 0.0 & 62.4 \\
\hline Pellecrinus & $\mathrm{C}$ & (Tour) & $\mathrm{C}$ & (Vise) & 358.9 & 330.9 & 28.0 & 0.0 & 28.0 \\
\hline Pernerocrinus & $\mathrm{D}$ & (Prag) & $\mathrm{D}$ & (Emsi) & 410.8 & 393.3 & 17.5 & 0.0 & 17.5 \\
\hline Pilidiocrinus & $\mathrm{P}$ & (Artin) & $\mathrm{P}$ & (Artin) & 290.1 & 279.3 & 10.8 & 0.0 & 10.8 \\
\hline Plicodendrocrinus & $\mathrm{O}$ & (Cara) & $\mathrm{D}$ & (Loch) & 460.9 & 410.8 & 50.1 & 0.0 & 50.1 \\
\hline Prochoidiocrinus & $\mathrm{P}$ & (Artin) & $\mathrm{P}$ & (Artin) & 290.1 & 279.3 & 10.8 & 0.0 & 10.8 \\
\hline Pskovicrinus & $\mathrm{D}$ & (Fras) & $\mathrm{D}$ & (Fras) & 382.7 & 372.2 & 10.5 & 0.0 & 10.5 \\
\hline Pyrenocrinus & $\mathrm{D}$ & (Emsi) & $\mathrm{D}$ & (Give) & 407.6 & 382.7 & 24.9 & 0.0 & 24.9 \\
\hline Quantoxocrinus & $\mathrm{D}$ & (Give) & $\mathrm{D}$ & (Fame) & 387.7 & 358.9 & 28.8 & 0.0 & 28.8 \\
\hline Rhadinocrinus & $\mathrm{D}$ & (Emsi) & $\mathrm{D}$ & (Give) & 407.6 & 382.7 & 24.9 & 0.0 & 24.9 \\
\hline RUTKOWSKICRINUS & $\mathrm{D}$ & (Give) & $\mathrm{D}$ & (Give) & 387.7 & 382.7 & 5.0 & 0.0 & 5.0 \\
\hline Saccosompsis & $\mathrm{C}$ & (Vise) & $\mathrm{C}$ & (Vise) & 346.7 & 330.9 & 15.8 & 0.0 & 15.8 \\
\hline SACRINUS & $\mathrm{D}$ & (Emsi) & $\mathrm{D}$ & (Eife) & 407.6 & 387.7 & 19.9 & 0.0 & 19.9 \\
\hline Schmidtocrinus & $\mathrm{D}$ & (Eife) & $\mathrm{D}$ & (Eife) & 393.3 & 387.7 & 5.6 & 0.0 & 5.6 \\
\hline Schultzicrinus & $\mathrm{D}$ & (Emsi) & $\mathrm{D}$ & (Emsi) & 407.6 & 393.3 & 14.3 & 0.0 & 14.3 \\
\hline Scoliocrinus & $\mathrm{D}$ & (Eife) & $\mathrm{D}$ & (Give) & 393.3 & 382.7 & 10.6 & 0.0 & 10.6 \\
\hline Sigambrocrinus & $\mathrm{D}$ & (Loch) & $\mathrm{D}$ & (Eife) & 419.2 & 387.7 & 31.5 & 0.0 & 31.5 \\
\hline Situlacrinus & $\mathrm{D}$ & (Emsi) & $\mathrm{D}$ & (Emsi) & 407.6 & 393.3 & 14.3 & 0.0 & 14.3 \\
\hline Sphaerocrinus & $\mathrm{D}$ & (Eife) & $\mathrm{D}$ & (Give) & 393.3 & 382.7 & 10.6 & 0.0 & 10.6 \\
\hline STEWBRECRINUS & $\mathrm{D}$ & (Loch) & $\mathrm{D}$ & (Loch) & 419.2 & 410.8 & 8.4 & 0.0 & 8.4 \\
\hline Streblocrinus & $\mathrm{D}$ & (Give) & $\mathrm{D}$ & (Give) & 387.7 & 382.7 & 5.0 & 0.0 & 5.0 \\
\hline Streptostomocrinus & $\mathrm{C}$ & (Vise) & $\mathrm{P}$ & (Artin) & 346.7 & 279.3 & 67.4 & 67.4 & 67.4 \\
\hline Sycocrinites & $\mathrm{C}$ & (Vise) & $\mathrm{C}$ & (Vise) & 346.7 & 330.9 & 15.8 & 0.0 & 15.8 \\
\hline Tenagocrinus & $\mathrm{P}$ & (Artin) & $\mathrm{P}$ & (Artin) & 290.1 & 279.3 & 10.8 & 0.0 & 10.8 \\
\hline Tetrapleurocrinus & $\mathrm{D}$ & (Eife) & $\mathrm{D}$ & (Give) & 393.3 & 382.7 & 10.6 & 0.0 & 10.6 \\
\hline Thetidicrinus & $\mathrm{P}$ & (Artin) & $\mathrm{P}$ & (Artin) & 290.1 & 279.3 & 10.8 & 0.0 & 10.8 \\
\hline Treocrinus & $\mathrm{D}$ & (Emsi) & $\mathrm{D}$ & (Emsi) & 407.6 & 393.3 & 14.3 & 0.0 & 14.3 \\
\hline Vadarocrinus & $\mathrm{D}$ & (Prag) & $\mathrm{D}$ & (Prag) & 410.8 & 407.6 & 3.2 & 0.0 & 3.2 \\
\hline Vasocrinus & $\mathrm{D}$ & (Loch) & $\mathrm{D}$ & (Give) & 419.2 & 382.7 & 36.5 & 0.0 & 36.5 \\
\hline ZYGIOCRINUS & $\mathrm{C}$ & (Tour) & $\mathrm{C}$ & (Tour) & 358.9 & 346.7 & 12.2 & 0.0 & 12.2 \\
\hline Zygotocrinus & $\mathrm{C}$ & (Tour) & $\mathrm{C}$ & (Tour) & 358.9 & 346.7 & 12.2 & 0.0 & 12.2 \\
\hline & & & & & \multirow{3}{*}{\multicolumn{2}{|c|}{$\begin{array}{r}\text { Average Duration: } \\
\text { Median: } \\
\text { N(Sample })\end{array}$}} & 25.6 & 56.2 & 26.4 \\
\hline & & & & & & & 14.3 & 67.4 & 14.3 \\
\hline & & & & & & & 120 & 19 & 115 \\
\hline \multicolumn{10}{|l|}{ ADVANCED CLADIDS } \\
\hline Aaglacrinus & $\mathrm{C}$ & (Mosc) & $\mathrm{C}$ & (Step) & 315.2 & 298.9 & 16.3 & 16.3 & 0.0 \\
\hline Aatocrinus & $\mathrm{C}$ & (Mosc) & $\mathrm{P}$ & (Wolf) & 315.2 & 279.3 & 35.9 & 35.9 & 35.9 \\
\hline Abrotocrinus & $\mathrm{C}$ & (Tour) & $\mathrm{C}$ & (Vise) & 358.9 & 330.9 & 28.0 & 0.0 & 28.0 \\
\hline Acylocrinus & $\mathrm{C}$ & (Tour) & $\mathrm{C}$ & (Vise) & 358.9 & 330.9 & 28.0 & 0.0 & 28.0 \\
\hline Adacrinus & $\mathrm{C}$ & (Mosc) & $\mathrm{C}$ & (Step) & 315.2 & 298.9 & 16.3 & 16.3 & 0.0 \\
\hline ADIAKRITOCRINUS & $\mathrm{C}$ & (Tour) & $\mathrm{C}$ & (Tour) & 358.9 & 346.7 & 12.2 & 0.0 & 12.2 \\
\hline Adinocrinus & $\mathrm{C}$ & (Vise) & $\mathrm{C}$ & (Vise) & 346.7 & 330.9 & 15.8 & 0.0 & 15.8 \\
\hline Aenigmocrinus & $\mathrm{C}$ & (Vise) & $\mathrm{C}$ & (Vise) & 346.7 & 330.9 & 15.8 & 0.0 & 15.8 \\
\hline Aesiocrinus & $\mathrm{C}$ & (Bash) & $\mathrm{C}$ & (Step) & 323.2 & 298.9 & 24.3 & 24.3 & 0.0 \\
\hline Affinocrinus & $\mathrm{C}$ & (Bash) & $\mathrm{C}$ & (Mosc) & 323.2 & 307 & 16.2 & 16.2 & 0.0 \\
\hline Agassizocrinus & $\mathrm{C}$ & (Vise) & $\mathrm{C}$ & (Serp) & 346.7 & 323.2 & 23.5 & 23.5 & 23.5 \\
\hline Aglaocrinus & $\mathrm{C}$ & (Bash) & $\mathrm{C}$ & (Step) & 323.2 & 298.9 & 24.3 & 24.3 & 0.0 \\
\hline Agnostocrinus & $\mathrm{P}$ & $($ Sakm) & $\mathrm{P}$ & (Word) & 295.5 & 265.1 & 30.4 & 30.4 & 30.4 \\
\hline Alcimocrinus & $\mathrm{C}$ & (Serp) & $\mathrm{C}$ & (Mosc) & 330.9 & 307 & 23.9 & 23.9 & 0.0 \\
\hline Allosocrinus & $\mathrm{C}$ & (Mosc) & $\mathrm{P}$ & (Sakm) & 315.2 & 290.1 & 25.1 & 25.1 & 0.0 \\
\hline
\end{tabular}




\begin{tabular}{|c|c|c|c|c|c|c|c|c|c|}
\hline AMABILICRINUS & $\mathrm{D}$ & (Fame) & $\mathrm{C}$ & (Tour) & 372.2 & 346.7 & 25.5 & 0.0 & 25.5 \\
\hline AMADEUSICRINUS & $\mathrm{D}$ & (Fame) & $\mathrm{D}$ & (Fame) & 372.2 & 358.9 & 13.3 & 0.0 & 13.3 \\
\hline Ampelocrinus & $\mathrm{C}$ & (Vise) & $\mathrm{C}$ & (Serp) & 346.7 & 323.2 & 23.5 & 23.5 & 23.5 \\
\hline AMPULLACRINUS & $\mathrm{C}$ & (Serp) & $\mathrm{C}$ & (Serp) & 330.9 & 323.2 & 7.7 & 7.7 & 0.0 \\
\hline Anartiocrinus & $\mathrm{C}$ & (Vise) & $\mathrm{C}$ & (Serp) & 346.7 & 323.2 & 23.5 & 23.5 & 23.5 \\
\hline Anchicrinus & $\mathrm{C}$ & (Bash) & $\mathrm{C}$ & (Mosc) & 323.2 & 307 & 16.2 & 16.2 & 0.0 \\
\hline Anechocrinus & $\mathrm{P}$ & (Artin) & $\mathrm{P}$ & (Artin) & 290.1 & 279.3 & 10.8 & 0.0 & 10.8 \\
\hline Anemetocrinus & $\mathrm{C}$ & (Vise) & $\mathrm{C}$ & (Vise) & 346.7 & 330.9 & 15.8 & 0.0 & 15.8 \\
\hline Anobasicrinus & $\mathrm{C}$ & (Bash) & $\mathrm{C}$ & (Step) & 323.2 & 298.9 & 24.3 & 24.3 & 0.0 \\
\hline Aphelecrinus & $\mathrm{D}$ & (Fame) & $\mathrm{C}$ & (Serp) & 372.2 & 323.2 & 49.0 & 49.0 & 49.0 \\
\hline Apographiocrinus & $\mathrm{C}$ & (Mosc) & $\mathrm{P}$ & (Artin) & 315.2 & 279.3 & 35.9 & 35.9 & 35.9 \\
\hline APOKRYPHOCRINUS & $\mathrm{C}$ & (Tour) & $\mathrm{C}$ & (Tour) & 358.9 & 346.7 & 12.2 & 0.0 & 12.2 \\
\hline Araeocrinus & $\mathrm{C}$ & (Mosc) & $\mathrm{C}$ & (Mosc) & 315.2 & 307 & 8.2 & 8.2 & 0.0 \\
\hline Archaeoisocrinus & $\mathrm{P}$ & (Artin) & $\mathrm{P}$ & (Artin) & 290.1 & 279.3 & 10.8 & 0.0 & 10.8 \\
\hline Arkacrinus & $\mathrm{C}$ & (Bash) & $\mathrm{C}$ & (Bash) & 323.2 & 315.2 & 8.0 & 8.0 & 0.0 \\
\hline Armenocrinus & $\mathrm{C}$ & (Vise) & $\mathrm{C}$ & (Vise) & 346.7 & 330.9 & 15.8 & 0.0 & 15.8 \\
\hline Arrectocrinus & $\mathrm{C}$ & (Step) & $\mathrm{P}$ & (Wolf) & 307 & 279.3 & 27.7 & 27.7 & 27.7 \\
\hline Arroyocrinus & $\mathrm{P}$ & (Sakm) & $\mathrm{P}$ & (Guad-u) & 295.5 & 259.8 & 35.7 & 35.7 & 35.7 \\
\hline Ascetocrinus & $\mathrm{C}$ & (Tour) & $\mathrm{C}$ & (Tour) & 358.9 & 346.7 & 12.2 & 0.0 & 12.2 \\
\hline Athlocrinus & $\mathrm{C}$ & (Bash) & $\mathrm{C}$ & (Step) & 323.2 & 298.9 & 24.3 & 24.3 & 0.0 \\
\hline Atokacrinus & $\mathrm{C}$ & (Bash) & $\mathrm{C}$ & (Mosc) & 323.2 & 307 & 16.2 & 16.2 & 0.0 \\
\hline Atrapocrinus & $\mathrm{C}$ & (Mosc) & $\mathrm{C}$ & (Mosc) & 315.2 & 307 & 8.2 & 8.2 & 0.0 \\
\hline Aulocrinus & $\mathrm{C}$ & (Vise) & $\mathrm{C}$ & (Vise) & 346.7 & 330.9 & 15.8 & 0.0 & 15.8 \\
\hline Basleocrinus & $\mathrm{P}$ & (Artin) & $\mathrm{P}$ & (Word) & 290.1 & 265.1 & 25.0 & 0.0 & 25.0 \\
\hline Bathronocrinus & $\mathrm{C}$ & (Mosc) & $\mathrm{C}$ & (Step) & 315.2 & 298.9 & 16.3 & 16.3 & 0.0 \\
\hline Belashovicrinus & $\mathrm{C}$ & (Step) & $\mathrm{P}$ & (Artin) & 307 & 279.3 & 27.7 & 27.7 & 27.7 \\
\hline Benthocrinus & $\mathrm{P}$ & (Artin) & $\mathrm{P}$ & (Artin) & 290.1 & 279.3 & 10.8 & 0.0 & 10.8 \\
\hline Bicidiocrinus & $\mathrm{C}$ & (Serp) & $\mathrm{C}$ & (Serp) & 330.9 & 323.2 & 7.7 & 7.7 & 0.0 \\
\hline Blothrocrinus & $\mathrm{D}$ & (Fame) & $\mathrm{C}$ & (Vise) & 372.2 & 330.9 & 41.3 & 0.0 & 41.3 \\
\hline Bollandocrinus & $\mathrm{C}$ & (Tour) & $\mathrm{C}$ & (Vise) & 358.9 & 330.9 & 28.0 & 0.0 & 28.0 \\
\hline BORUCRINUS & $\mathrm{C}$ & (Tour) & $\mathrm{C}$ & (Vise) & 358.9 & 330.9 & 28.0 & 0.0 & 28.0 \\
\hline Brabeocrinus & $\mathrm{C}$ & (Bash) & $\mathrm{P}$ & (Sakm) & 323.2 & 290.1 & 33.1 & 33.1 & 0.0 \\
\hline Bridgerocrinus & $\mathrm{D}$ & (Fame) & $\mathrm{C}$ & (Tour) & 372.2 & 346.7 & 25.5 & 0.0 & 25.5 \\
\hline Bronaughocrinus & $\mathrm{C}$ & (Vise) & $\mathrm{C}$ & (Serp) & 346.7 & 323.2 & 23.5 & 23.5 & 23.5 \\
\hline Brychiocrinus & $\mathrm{C}$ & (Mosc) & $\mathrm{C}$ & (Mosc) & 315.2 & 307 & 8.2 & 8.2 & 0.0 \\
\hline BUFALOCRINUS & $\mathrm{D}$ & (Fame) & $\mathrm{D}$ & (Fame) & 372.2 & 358.9 & 13.3 & 0.0 & 13.3 \\
\hline Bursacrinus & $\mathrm{C}$ & (Tour) & $\mathrm{C}$ & (Tour) & 358.9 & 346.7 & 12.2 & 0.0 & 12.2 \\
\hline Cadocrinus & $\mathrm{P}$ & (Artin) & $\mathrm{P}$ & (Artin) & 290.1 & 279.3 & 10.8 & 0.0 & 10.8 \\
\hline Calceolispongia & $\mathrm{P}$ & (Sakm) & $\mathrm{P}$ & (Word) & 295.5 & 265.1 & 30.4 & 30.4 & 30.4 \\
\hline Campbellicrinus & $\mathrm{P}$ & (Sakm) & $\mathrm{P}$ & (Artin) & 295.5 & 279.3 & 16.2 & 16.2 & 16.2 \\
\hline Carcinocrinus & $\mathrm{C}$ & (Serp) & $\mathrm{C}$ & (Serp) & 330.9 & 323.2 & 7.7 & 7.7 & 0.0 \\
\hline Catactocrinus & $\mathrm{D}$ & (Fras) & $\mathrm{D}$ & (Fame) & 382.7 & 358.9 & 23.8 & 0.0 & 23.8 \\
\hline Cathetocrinus & $\mathrm{C}$ & (Step) & $\mathrm{C}$ & (Step) & 307 & 298.9 & 8.1 & 8.1 & 0.0 \\
\hline Celonocrinus & $\mathrm{C}$ & (Mosc) & $\mathrm{P}$ & (Sakm) & 315.2 & 290.1 & 25.1 & 25.1 & 0.0 \\
\hline Cercidocrinus & $\mathrm{C}$ & (Tour) & $\mathrm{C}$ & (Tour) & 358.9 & 346.7 & 12.2 & 0.0 & 12.2 \\
\hline Charientocrinus & $\mathrm{D}$ & (Give) & $\mathrm{D}$ & (Fras) & 387.7 & 372.2 & 15.5 & 0.0 & 15.5 \\
\hline Chlidonocrinus & $\mathrm{C}$ & (Serp) & $\mathrm{C}$ & (Step) & 330.9 & 298.9 & 32.0 & 32.0 & 0.0 \\
\hline Clathrocrinus & $\mathrm{C}$ & (Mosc) & $\mathrm{C}$ & (Step) & 315.2 & 298.9 & 16.3 & 16.3 & 0.0 \\
\hline Coeliocrinus & $\mathrm{C}$ & (Tour) & $\mathrm{C}$ & (Tour) & 358.9 & 346.7 & 12.2 & 0.0 & 12.2 \\
\hline Coenocrinus & $\mathrm{P}$ & (Word) & $\mathrm{P}$ & (Word) & 268.8 & 265.1 & 3.7 & 0.0 & 3.7 \\
\hline Contignatindocrinus & $\mathrm{P}$ & (Artin) & $\mathrm{P}$ & (Artin) & 290.1 & 279.3 & 10.8 & 0.0 & 10.8 \\
\hline Contocrinus & $\mathrm{C}$ & (Mosc) & $\mathrm{P}$ & (Sakm) & 315.2 & 290.1 & 25.1 & 25.1 & 0.0 \\
\hline Corematocrinus & $\mathrm{D}$ & (Fras) & $\mathrm{D}$ & (Fras) & 382.7 & 372.2 & 10.5 & 0.0 & 10.5 \\
\hline
\end{tabular}




\begin{tabular}{|c|c|c|c|c|c|c|c|c|c|}
\hline Corythocrinus & $\mathrm{C}$ & (Vise) & $\mathrm{C}$ & (Vise) & 346.7 & 330.9 & 15.8 & 0.0 & 15.8 \\
\hline Cosmetocrinus & $\mathrm{D}$ & (Fame) & $\mathrm{C}$ & (Serp) & 372.2 & 323.2 & 49.0 & 49.0 & 49.0 \\
\hline Cricocrinus & $\mathrm{C}$ & (Mosc) & $\mathrm{C}$ & (Mosc) & 315.2 & 307 & 8.2 & 8.2 & 0.0 \\
\hline Crinophagus & $\mathrm{P}$ & (Artin) & $\mathrm{P}$ & (Artin) & 290.1 & 279.3 & 10.8 & 0.0 & 10.8 \\
\hline Cromyocrinus & $\mathrm{C}$ & (Vise) & $\mathrm{C}$ & (Mosc) & 346.7 & 307 & 39.7 & 39.7 & 39.7 \\
\hline Cryphiocrinus & $\mathrm{C}$ & (Serp) & $\mathrm{C}$ & (Serp) & 330.9 & 323.2 & 7.7 & 7.7 & 0.0 \\
\hline Culmicrinus & $\mathrm{C}$ & (Tour) & $\mathrm{C}$ & (Serp) & 358.9 & 323.2 & 35.7 & 35.7 & 35.7 \\
\hline Cupressocrinites & $\mathrm{D}$ & (Prag) & $\mathrm{D}$ & (Fame) & 410.8 & 358.9 & 51.9 & 0.0 & 51.9 \\
\hline Cydrocrinus & $\mathrm{C}$ & (Tour) & $\mathrm{C}$ & (Vise) & 358.9 & 330.9 & 28.0 & 0.0 & 28.0 \\
\hline Cymbiocrinus & $\mathrm{C}$ & (Vise) & $\mathrm{C}$ & (Bash) & 346.7 & 315.2 & 31.5 & 31.5 & 31.5 \\
\hline Dasciocrinus & $\mathrm{C}$ & (Vise) & $\mathrm{C}$ & (Serp) & 346.7 & 323.2 & 23.5 & 23.5 & 23.5 \\
\hline Decadocrinus & $\mathrm{D}$ & (Give) & $\mathrm{C}$ & (Vise) & 387.7 & 330.9 & 56.8 & 0.0 & 56.8 \\
\hline Delocrinus & $\mathrm{C}$ & (Mosc) & $\mathrm{P}$ & (Guad-u) & 315.2 & 259.8 & 55.4 & 55.4 & 55.4 \\
\hline Delocrinus & $\mathrm{C}$ & (Vise) & $\mathrm{P}$ & (Artin) & 346.7 & 279.3 & 67.4 & 67.4 & 67.4 \\
\hline Denariocrinus & $\mathrm{D}$ & (Emsi) & $\mathrm{D}$ & (Emsi) & 407.6 & 393.3 & 14.3 & 0.0 & 14.3 \\
\hline Depaocrinus & $\mathrm{P}$ & (Artin) & $\mathrm{P}$ & (Artin) & 290.1 & 279.3 & 10.8 & 0.0 & 10.8 \\
\hline Derbiocrinus & $\mathrm{C}$ & (Vise) & $\mathrm{C}$ & (Vise) & 346.7 & 330.9 & 15.8 & 0.0 & 15.8 \\
\hline DERORHETHOCRINUS & $\mathrm{C}$ & (Tour) & $\mathrm{C}$ & (Tour) & 358.9 & 346.7 & 12.2 & 0.0 & 12.2 \\
\hline Dicromyocrinus & $\mathrm{C}$ & (Serp) & $\mathrm{C}$ & (Step) & 330.9 & 298.9 & 32.0 & 32.0 & 0.0 \\
\hline Dinotocrinus & $\mathrm{C}$ & (Vise) & $\mathrm{C}$ & (Vise) & 346.7 & 330.9 & 15.8 & 0.0 & 15.8 \\
\hline Diphuicrinus & $\mathrm{C}$ & (Bash) & $\mathrm{C}$ & (Step) & 323.2 & 298.9 & 24.3 & 24.3 & 0.0 \\
\hline Eidosocrinus & $\mathrm{P}$ & (Artin) & $\mathrm{P}$ & (Artin) & 290.1 & 279.3 & 10.8 & 0.0 & 10.8 \\
\hline Eirmocrinus & $\mathrm{C}$ & (Mosc) & $\mathrm{C}$ & (Mosc) & 315.2 & 307 & 8.2 & 8.2 & 0.0 \\
\hline Ekteinocrinus & $\mathrm{P}$ & (Artin) & $\mathrm{P}$ & (Artin) & 290.1 & 279.3 & 10.8 & 0.0 & 10.8 \\
\hline Elassocrinus & $\mathrm{P}$ & (Artin) & $\mathrm{P}$ & (Artin) & 290.1 & 279.3 & 10.8 & 0.0 & 10.8 \\
\hline Elibatocrinus & $\mathrm{C}$ & (Mosc) & $\mathrm{P}$ & (Asse) & 315.2 & 295.5 & 19.7 & 19.7 & 0.0 \\
\hline Elibatocrinus & $\mathrm{C}$ & (Mosc) & $\mathrm{P}$ & (Artin) & 315.2 & 279.3 & 35.9 & 35.9 & 35.9 \\
\hline Endelocrinus & $\mathrm{C}$ & (Bash) & $\mathrm{P}$ & (Sakm) & 323.2 & 290.1 & 33.1 & 33.1 & 0.0 \\
\hline Eoindocrinus & $\mathrm{P}$ & (Artin) & $\mathrm{P}$ & (Artin) & 290.1 & 279.3 & 10.8 & 0.0 & 10.8 \\
\hline Eperisocrinus & $\mathrm{C}$ & (Step) & $\mathrm{C}$ & (Step) & 307 & 298.9 & 8.1 & 8.1 & 0.0 \\
\hline Epipetschoracrinus & $\mathrm{P}$ & (Wolf) & $\mathrm{P}$ & (Wolf) & 298.9 & 279.3 & 19.6 & 19.6 & 19.6 \\
\hline Eratocrinus & $\mathrm{C}$ & (Tour) & $\mathrm{C}$ & (Vise) & 358.9 & 330.9 & 28.0 & 0.0 & 28.0 \\
\hline Erisocrinus & $\mathrm{C}$ & (Bash) & $\mathrm{P}$ & (Word) & 323.2 & 265.1 & 58.1 & 58.1 & 58.1 \\
\hline Ethelocrinus & $\mathrm{C}$ & (Bash) & $\mathrm{C}$ & (Step) & 323.2 & 298.9 & 24.3 & 24.3 & 0.0 \\
\hline Euerisocrinus & $\mathrm{C}$ & (Step) & $\mathrm{C}$ & (Step) & 307 & 298.9 & 8.1 & 8.1 & 0.0 \\
\hline Eupachycrinus & $\mathrm{C}$ & (Vise) & $\mathrm{C}$ & (Serp) & 346.7 & 323.2 & 23.5 & 23.5 & 23.5 \\
\hline Exaetocrinus & $\mathrm{C}$ & (Vise) & $\mathrm{C}$ & (Step) & 346.7 & 298.9 & 47.8 & 47.8 & 47.8 \\
\hline Exochocrinus & $\mathrm{C}$ & (Vise) & $\mathrm{C}$ & (Serp) & 346.7 & 323.2 & 23.5 & 23.5 & 23.5 \\
\hline Exocrinus & $\mathrm{C}$ & (Mosc) & $\mathrm{P}$ & (Sakm) & 315.2 & 290.1 & 25.1 & 25.1 & 0.0 \\
\hline Exoriocrinus & $\mathrm{C}$ & (Mosc) & $\mathrm{C}$ & (Step) & 315.2 & 298.9 & 16.3 & 16.3 & 0.0 \\
\hline Exterocrinus & $\mathrm{C}$ & (Bash) & $\mathrm{C}$ & (Bash) & 323.2 & 315.2 & 8.0 & 8.0 & 0.0 \\
\hline Fifeocrinus & $\mathrm{C}$ & (Vise) & $\mathrm{C}$ & (Serp) & 346.7 & 323.2 & 23.5 & 23.5 & 23.5 \\
\hline Forthocrinus & $\mathrm{C}$ & (Vise) & $\mathrm{C}$ & (Vise) & 346.7 & 330.9 & 15.8 & 0.0 & 15.8 \\
\hline GAELICRINUS & $\mathrm{C}$ & (Tour) & $\mathrm{C}$ & (Tour) & 358.9 & 346.7 & 12.2 & 0.0 & 12.2 \\
\hline Galateacrinus & $\mathrm{C}$ & (Mosc) & $\mathrm{P}$ & (Artin) & 315.2 & 279.3 & 35.9 & 35.9 & 35.9 \\
\hline GELASINOCRINUS & $\mathrm{C}$ & (Tour) & $\mathrm{C}$ & (Tour) & 358.9 & 346.7 & 12.2 & 0.0 & 12.2 \\
\hline Gilmocrinus & $\mathrm{C}$ & (Tour) & $\mathrm{C}$ & (Vise) & 358.9 & 330.9 & 28.0 & 0.0 & 28.0 \\
\hline Glaukosocrinus & $\mathrm{C}$ & (Bash) & $\mathrm{P}$ & (Wolf) & 323.2 & 279.3 & 43.9 & 43.9 & 43.9 \\
\hline Glossocrinus & $\mathrm{D}$ & (Give) & $\mathrm{D}$ & (Fame) & 387.7 & 358.9 & 28.8 & 0.0 & 28.8 \\
\hline Goleocrinus & $\mathrm{C}$ & (Vise) & $\mathrm{C}$ & (Mosc) & 346.7 & 307 & 39.7 & 39.7 & 39.7 \\
\hline Graffhamicrinus & $\mathrm{C}$ & (Mosc) & $\mathrm{P}$ & (Wolf) & 315.2 & 279.3 & 35.9 & 35.9 & 35.9 \\
\hline Graphiocrinus & $\mathrm{C}$ & (Tour) & $\mathrm{P}$ & (Word) & 358.9 & 265.1 & 93.8 & 93.8 & 93.8 \\
\hline GRABAUICRINUS & $\mathrm{D}$ & (Fame) & $\mathrm{D}$ & (Fame) & 372.2 & 358.9 & 13.3 & 0.0 & 13.3 \\
\hline
\end{tabular}




\begin{tabular}{|c|c|c|c|c|c|c|c|c|c|}
\hline GULINOCRINUS & $\mathrm{C}$ & (Tour) & $\mathrm{C}$ & (Tour) & 358.9 & 346.7 & 12.2 & 0.0 & 12.2 \\
\hline Haeretocrinus & $\mathrm{C}$ & (Mosc) & $\mathrm{C}$ & (Step) & 315.2 & 298.9 & 16.3 & 16.3 & 0.0 \\
\hline Hallocrinus & $\mathrm{D}$ & (Emsi) & $\mathrm{D}$ & (Fras) & 407.6 & 372.2 & 35.4 & 0.0 & 35.4 \\
\hline Halogetocrinus & $\mathrm{C}$ & (Mosc) & $\mathrm{P}$ & (Asse) & 315.2 & 295.5 & 19.7 & 19.7 & 0.0 \\
\hline Harmostocrinus & $\mathrm{C}$ & (Vise) & $\mathrm{C}$ & (Serp) & 346.7 & 323.2 & 23.5 & 23.5 & 23.5 \\
\hline Heliosocrinus & $\mathrm{C}$ & (Vise) & $\mathrm{C}$ & (Bash) & 346.7 & 315.2 & 31.5 & 31.5 & 31.5 \\
\hline Hemiindocrinus & $\mathrm{P}$ & (Artin) & $\mathrm{P}$ & (Artin) & 290.1 & 279.3 & 10.8 & 0.0 & 10.8 \\
\hline Hemimollocrinus & $\mathrm{P}$ & (Artin) & $\mathrm{P}$ & (Artin) & 290.1 & 279.3 & 10.8 & 0.0 & 10.8 \\
\hline Histocrinus & $\mathrm{C}$ & (Tour) & $\mathrm{C}$ & (Vise) & 358.9 & 330.9 & 28.0 & 0.0 & 28.0 \\
\hline Holcocrinus & $\mathrm{D}$ & (Fame) & $\mathrm{C}$ & (Vise) & 372.2 & 330.9 & 41.3 & 0.0 & 41.3 \\
\hline Hosieocrinus & $\mathrm{C}$ & (Vise) & $\mathrm{C}$ & (Vise) & 346.7 & 330.9 & 15.8 & 0.0 & 15.8 \\
\hline Huqficrinus & $\mathrm{P}$ & (Sakm) & $\mathrm{P}$ & (Sakm) & 295.5 & 290.1 & 5.4 & 5.4 & 0.0 \\
\hline HUTKOCRINUS & $\mathrm{C}$ & (Tour) & $\mathrm{C}$ & (Tour) & 358.9 & 346.7 & 12.2 & 0.0 & 12.2 \\
\hline Hydreionocrinus & $\mathrm{C}$ & (Vise) & $\mathrm{C}$ & (Serp) & 346.7 & 323.2 & 23.5 & 23.5 & 23.5 \\
\hline Hydriocrinus & $\mathrm{C}$ & (Mosc) & $\mathrm{C}$ & (Step) & 315.2 & 298.9 & 16.3 & 16.3 & 0.0 \\
\hline Hylodecrinus & $\mathrm{C}$ & (Vise) & $\mathrm{C}$ & (Vise) & 346.7 & 330.9 & 15.8 & 0.0 & 15.8 \\
\hline Hypermorphocrinus & $\mathrm{P}$ & (Artin) & $\mathrm{P}$ & (Artin) & 290.1 & 279.3 & 10.8 & 0.0 & 10.8 \\
\hline Hypselocrinus & $\mathrm{D}$ & (Fame) & $\mathrm{C}$ & (Serp) & 372.2 & 323.2 & 49.0 & 49.0 & 49.0 \\
\hline Idosocrinus & $\mathrm{C}$ & (Vise) & $\mathrm{C}$ & (Vise) & 346.7 & 330.9 & 15.8 & 0.0 & 15.8 \\
\hline Indocrinus & $\mathrm{P}$ & (Artin) & $\mathrm{P}$ & (Artin) & 290.1 & 279.3 & 10.8 & 0.0 & 10.8 \\
\hline Jimbacrinus & $\mathrm{P}$ & (Sakm) & $\mathrm{P}$ & (Artin) & 295.5 & 279.3 & 16.2 & 16.2 & 16.2 \\
\hline JULIETICRINUS & $\mathrm{D}$ & (Fame) & $\mathrm{D}$ & (Fame) & 372.2 & 358.9 & 13.3 & 0.0 & 13.3 \\
\hline Kansacrinus & $\mathrm{C}$ & (Step) & $\mathrm{P}$ & (Wolf) & 307 & 279.3 & 27.7 & 27.7 & 27.7 \\
\hline Kansacrinus & $\mathrm{C}$ & (Step) & $\mathrm{P}$ & (Wolf) & 307 & 279.3 & 27.7 & 27.7 & 27.7 \\
\hline Laccocrinus & $\mathrm{P}$ & (Artin) & $\mathrm{P}$ & (Artin) & 290.1 & 279.3 & 10.8 & 0.0 & 10.8 \\
\hline Lanecrinus & $\mathrm{C}$ & (Tour) & $\mathrm{C}$ & (Mosc) & 358.9 & 307 & 51.9 & 51.9 & 51.9 \\
\hline Lasanocrinus & $\mathrm{C}$ & (Bash) & $\mathrm{C}$ & (Mosc) & 323.2 & 307 & 16.2 & 16.2 & 0.0 \\
\hline Laudonocrinus & $\mathrm{C}$ & (Bash) & $\mathrm{C}$ & (Step) & 323.2 & 298.9 & 24.3 & 24.3 & 0.0 \\
\hline Lebetocrinus & $\mathrm{C}$ & (Tour) & $\mathrm{C}$ & (Vise) & 358.9 & 330.9 & 28.0 & 0.0 & 28.0 \\
\hline Lecobasicrinus & $\mathrm{C}$ & (Mosc) & $\mathrm{C}$ & (Step) & 315.2 & 298.9 & 16.3 & 16.3 & 0.0 \\
\hline Lekocrinus & $\mathrm{C}$ & (Vise) & $\mathrm{C}$ & (Vise) & 346.7 & 330.9 & 15.8 & 0.0 & 15.8 \\
\hline Linobrachiocrinus & $\mathrm{D}$ & (Fras) & $\mathrm{D}$ & (Fras) & 382.7 & 372.2 & 10.5 & 0.0 & 10.5 \\
\hline Linocrinus & $\mathrm{C}$ & (Tour) & $\mathrm{C}$ & (Serp) & 358.9 & 323.2 & 35.7 & 35.7 & 35.7 \\
\hline Liparocrinus & $\mathrm{D}$ & (Fras) & $\mathrm{D}$ & (Fras) & 382.7 & 372.2 & 10.5 & 0.0 & 10.5 \\
\hline Lobalocrinus & $\mathrm{C}$ & (Step) & $\mathrm{C}$ & (Step) & 307 & 298.9 & 8.1 & 8.1 & 0.0 \\
\hline Logocrinus & $\mathrm{D}$ & (Give) & $\mathrm{C}$ & (Tour) & 387.7 & 346.7 & 41.0 & 0.0 & 41.0 \\
\hline Lopadiocrinus & $\mathrm{P}$ & (Artin) & $\mathrm{P}$ & (Artin) & 290.1 & 279.3 & 10.8 & 0.0 & 10.8 \\
\hline Lophocrinus & $\mathrm{C}$ & (Vise) & $\mathrm{C}$ & (Vise) & 346.7 & 330.9 & 15.8 & 0.0 & 15.8 \\
\hline LOROCRINUS & $\mathrm{C}$ & (Tour) & $\mathrm{C}$ & (Tour) & 358.9 & 346.7 & 12.2 & 0.0 & 12.2 \\
\hline MAEVECRINUS & $\mathrm{C}$ & (Tour) & $\mathrm{C}$ & (Tour) & 358.9 & 346.7 & 12.2 & 0.0 & 12.2 \\
\hline Malaiocrinus & $\mathrm{C}$ & (Mosc) & $\mathrm{P}$ & (Artin) & 315.2 & 279.3 & 35.9 & 35.9 & 35.9 \\
\hline Mantikosocrinus & $\mathrm{C}$ & (Vise) & $\mathrm{C}$ & (Serp) & 346.7 & 323.2 & 23.5 & 23.5 & 23.5 \\
\hline Maragnicrinus & $\mathrm{D}$ & (Fras) & $\mathrm{D}$ & (Fras) & 382.7 & 372.2 & 10.5 & 0.0 & 10.5 \\
\hline Marathonocrinus & $\mathrm{C}$ & (Bash) & $\mathrm{C}$ & (Mosc) & 323.2 & 307 & 16.2 & 16.2 & 0.0 \\
\hline Mathericrinus & $\mathrm{C}$ & (Bash) & $\mathrm{C}$ & (Mosc) & 323.2 & 307 & 16.2 & 16.2 & 0.0 \\
\hline Meganotocrinus & $\mathrm{P}$ & (Artin) & $\mathrm{P}$ & (Road) & 290.1 & 268.8 & 21.3 & 0.0 & 21.3 \\
\hline Melbacrinus & $\mathrm{C}$ & (Step) & $\mathrm{C}$ & (Step) & 307 & 298.9 & 8.1 & 8.1 & 0.0 \\
\hline Meniscocrinus & $\mathrm{C}$ & (Vise) & $\mathrm{C}$ & (Vise) & 346.7 & 330.9 & 15.8 & 0.0 & 15.8 \\
\hline Metacalceolispongia & $\mathrm{P}$ & (Wuchia) & $\mathrm{P}$ & (Wuchia) & 259.8 & 254.2 & 5.6 & 0.0 & 5.6 \\
\hline Metacromyocrinus & $\mathrm{C}$ & (Bash) & $\mathrm{C}$ & (Step) & 323.2 & 298.9 & 24.3 & 24.3 & 0.0 \\
\hline Metaffinocrinus & $\mathrm{C}$ & (Mosc) & $\mathrm{C}$ & (Mosc) & 315.2 & 307 & 8.2 & 8.2 & 0.0 \\
\hline Metaindocrinus & $\mathrm{P}$ & (Word) & $\mathrm{P}$ & (Word) & 268.8 & 265.1 & 3.7 & 0.0 & 3.7 \\
\hline Metaperimestocrinus & $\mathrm{C}$ & (Bash) & $\mathrm{C}$ & (Step) & 323.2 & 298.9 & 24.3 & 24.3 & 0.0 \\
\hline
\end{tabular}




\begin{tabular}{|c|c|c|c|c|c|c|c|c|c|}
\hline Metutharocrinus & $\mathrm{C}$ & (Bash) & $\mathrm{C}$ & (Bash) & 323.2 & 315.2 & 8.0 & 8.0 & 0.0 \\
\hline Miatschkovocrinus & $\mathrm{C}$ & (Mosc) & $\mathrm{C}$ & (Step) & 315.2 & 298.9 & 16.3 & 16.3 & 0.0 \\
\hline Microcaracrinus & $\mathrm{C}$ & (Mosc) & $\mathrm{P}$ & (Sakm) & 315.2 & 290.1 & 25.1 & 25.1 & 0.0 \\
\hline Minilyacrinus & $\mathrm{P}$ & (Sakm) & $\mathrm{P}$ & (Sakm) & 295.5 & 290.1 & 5.4 & 5.4 & 0.0 \\
\hline Missouricrinus & $\mathrm{C}$ & (Tour) & $\mathrm{C}$ & (Tour) & 358.9 & 346.7 & 12.2 & 0.0 & 12.2 \\
\hline Moapacrinus & $\mathrm{C}$ & (Step) & $\mathrm{P}$ & (Artin) & 307 & 279.3 & 27.7 & 27.7 & 27.7 \\
\hline Mollocrinus & $\mathrm{P}$ & (Artin) & $\mathrm{P}$ & (Artin) & 290.1 & 279.3 & 10.8 & 0.0 & 10.8 \\
\hline Mooreocrinus & $\mathrm{C}$ & (Serp) & $\mathrm{C}$ & (Step) & 330.9 & 298.9 & 32.0 & 32.0 & 0.0 \\
\hline Morro(Wolf)rinus & $\mathrm{C}$ & (Bash) & $\mathrm{C}$ & (Bash) & 323.2 & 315.2 & 8.0 & 8.0 & 0.0 \\
\hline (Mosc)ovicrinus & $\mathrm{C}$ & (Mosc) & $\mathrm{P}$ & (Sakm) & 315.2 & 290.1 & 25.1 & 25.1 & 0.0 \\
\hline Moundocrinus & $\mathrm{C}$ & (Mosc) & $\mathrm{C}$ & (Step) & 315.2 & 298.9 & 16.3 & 16.3 & 0.0 \\
\hline Nacocrinus & $\mathrm{C}$ & (Mosc) & $\mathrm{C}$ & (Mosc) & 315.2 & 307 & 8.2 & 8.2 & 0.0 \\
\hline Nactocrinus & $\mathrm{C}$ & (Tour) & $\mathrm{C}$ & (Tour) & 358.9 & 346.7 & 12.2 & 0.0 & 12.2 \\
\hline Nebraskacrinus & $\mathrm{P}$ & (Wolf) & $\mathrm{P}$ & (Wolf) & 298.9 & 279.3 & 19.6 & 19.6 & 19.6 \\
\hline Neocatacrinus & $\mathrm{C}$ & (Step) & $\mathrm{C}$ & (Step) & 307 & 298.9 & 8.1 & 8.1 & 0.0 \\
\hline Neoprotencrinus & $\mathrm{C}$ & (Mosc) & $\mathrm{C}$ & (Step) & 315.2 & 298.9 & 16.3 & 16.3 & 0.0 \\
\hline Neozeacrinus & $\mathrm{C}$ & (Mosc) & $\mathrm{P}$ & (Guad-u) & 315.2 & 259.8 & 55.4 & 55.4 & 55.4 \\
\hline Neozeacrinus & $\mathrm{P}$ & (Sakm) & $\mathrm{P}$ & (Artin) & 295.5 & 279.3 & 16.2 & 16.2 & 16.2 \\
\hline Notiocrinus & $\mathrm{P}$ & (Artin) & $\mathrm{P}$ & (Artin) & 290.1 & 279.3 & 10.8 & 0.0 & 10.8 \\
\hline Nowracrinus & $\mathrm{P}$ & (Artin) & $\mathrm{P}$ & (Road) & 290.1 & 268.8 & 21.3 & 0.0 & 21.3 \\
\hline NUDALOCRINUS & $\mathrm{C}$ & (Tour) & $\mathrm{C}$ & (Tour) & 358.9 & 346.7 & 12.2 & 0.0 & 12.2 \\
\hline OKACRINUS & $\mathrm{C}$ & (Serp) & $\mathrm{C}$ & (Serp) & 330.9 & 323.2 & 7.7 & 7.7 & 0.0 \\
\hline Oklahomacrinus & $\mathrm{C}$ & (Mosc) & $\mathrm{P}$ & (Artin) & 315.2 & 279.3 & 35.9 & 35.9 & 35.9 \\
\hline Omanicrinus & $\mathrm{P}$ & (Sakm) & $\mathrm{P}$ & (Sakm) & 295.5 & 290.1 & 5.4 & 5.4 & 0.0 \\
\hline Ophiurocrinus & $\mathrm{C}$ & (Tour) & $\mathrm{C}$ & (Mosc) & 358.9 & 307 & 51.9 & 51.9 & 51.9 \\
\hline Oxynocrinus & $\mathrm{C}$ & (Bash) & $\mathrm{C}$ & (Bash) & 323.2 & 315.2 & 8.0 & 8.0 & 0.0 \\
\hline Pachylocrinus & $\mathrm{D}$ & (Fame) & $\mathrm{C}$ & (Serp) & 372.2 & 323.2 & 49.0 & 49.0 & 49.0 \\
\hline Paianocrinus & $\mathrm{C}$ & (Serp) & $\mathrm{C}$ & (Serp) & 330.9 & 323.2 & 7.7 & 7.7 & 0.0 \\
\hline Palmerocrinus & $\mathrm{C}$ & (Bash) & $\mathrm{C}$ & (Mosc) & 323.2 & 307 & 16.2 & 16.2 & 0.0 \\
\hline Parabursacrinus & $\mathrm{P}$ & (Sakm) & $\mathrm{P}$ & (Artin) & 295.5 & 279.3 & 16.2 & 16.2 & 16.2 \\
\hline Paracosmetocrinus & $\mathrm{C}$ & (Tour) & $\mathrm{C}$ & (Tour) & 358.9 & 346.7 & 12.2 & 0.0 & 12.2 \\
\hline Paracromyocrinus & $\mathrm{C}$ & (Bash) & $\mathrm{P}$ & (Wolf) & 323.2 & 279.3 & 43.9 & 43.9 & 43.9 \\
\hline Paracymbiocrinus & $\mathrm{C}$ & (Serp) & $\mathrm{C}$ & (Serp) & 330.9 & 323.2 & 7.7 & 7.7 & 0.0 \\
\hline Paradelocrinus & $\mathrm{C}$ & (Bash) & $\mathrm{C}$ & (Step) & 323.2 & 298.9 & 24.3 & 24.3 & 0.0 \\
\hline Paragassizocrinus & $\mathrm{C}$ & (Bash) & $\mathrm{C}$ & (Step) & 323.2 & 298.9 & 24.3 & 24.3 & 0.0 \\
\hline Paragraphiocrinus & $\mathrm{P}$ & (Artin) & $\mathrm{P}$ & (Artin) & 290.1 & 279.3 & 10.8 & 0.0 & 10.8 \\
\hline Parascytalocrinus & $\mathrm{C}$ & (Vise) & $\mathrm{C}$ & (Vise) & 346.7 & 330.9 & 15.8 & 0.0 & 15.8 \\
\hline Parastachyocrinus & $\mathrm{P}$ & (Artin) & $\mathrm{P}$ & (Artin) & 290.1 & 279.3 & 10.8 & 0.0 & 10.8 \\
\hline Paratimorocidaris & $\mathrm{P}$ & (Artin) & $\mathrm{P}$ & (Artin) & 290.1 & 279.3 & 10.8 & 0.0 & 10.8 \\
\hline Parazeacrinites & $\mathrm{C}$ & (Vise) & $\mathrm{C}$ & (Vise) & 346.7 & 330.9 & 15.8 & 0.0 & 15.8 \\
\hline Parethelocrinus & $\mathrm{C}$ & (Bash) & $\mathrm{C}$ & (Step) & 323.2 & 298.9 & 24.3 & 24.3 & 0.0 \\
\hline Parindocrinus & $\mathrm{P}$ & (Artin) & $\mathrm{P}$ & (Artin) & 290.1 & 279.3 & 10.8 & 0.0 & 10.8 \\
\hline Parspaniocrinus & $\mathrm{P}$ & (Wolf) & $\mathrm{P}$ & (Wolf) & 298.9 & 279.3 & 19.6 & 19.6 & 19.6 \\
\hline Parulocrinus & $\mathrm{C}$ & (Mosc) & $\mathrm{P}$ & (Artin) & 315.2 & 279.3 & 35.9 & 35.9 & 35.9 \\
\hline Pedinocrinus & $\mathrm{C}$ & (Vise) & $\mathrm{C}$ & (Vise) & 346.7 & 330.9 & 15.8 & 0.0 & 15.8 \\
\hline Pegocrinus & $\mathrm{C}$ & (Mosc) & $\mathrm{C}$ & (Mosc) & 315.2 & 307 & 8.2 & 8.2 & 0.0 \\
\hline Pelecocrinus & $\mathrm{C}$ & (Tour) & $\mathrm{C}$ & (Serp) & 358.9 & 323.2 & 35.7 & 35.7 & 35.7 \\
\hline Pentaramicrinus & $\mathrm{C}$ & (Vise) & $\mathrm{C}$ & (Serp) & 346.7 & 323.2 & 23.5 & 23.5 & 23.5 \\
\hline Pentaxocrinus & $\mathrm{P}$ & (Artin) & $\mathrm{P}$ & (Artin) & 290.1 & 279.3 & 10.8 & 0.0 & 10.8 \\
\hline Pentececrinus & $\mathrm{D}$ & (Fame) & $\mathrm{D}$ & (Fame) & 372.2 & 358.9 & 13.3 & 0.0 & 13.3 \\
\hline Perimestocrinus & $\mathrm{C}$ & (Bash) & $\mathrm{P}$ & (Sakm) & 323.2 & 290.1 & 33.1 & 33.1 & 0.0 \\
\hline Permiocrinus & $\mathrm{P}$ & (Artin) & $\mathrm{P}$ & (Artin) & 290.1 & 279.3 & 10.8 & 0.0 & 10.8 \\
\hline Petalambicrinus & $\mathrm{C}$ & (Step) & $\mathrm{C}$ & (Step) & 307 & 298.9 & 8.1 & 8.1 & 0.0 \\
\hline
\end{tabular}




\begin{tabular}{|c|c|c|c|c|c|c|c|c|c|}
\hline Petschoracrinus & $\mathrm{C}$ & (Mosc) & $\mathrm{P}$ & (Artin) & 315.2 & 279.3 & 35.9 & 35.9 & 35.9 \\
\hline Petschoracrinus & $\mathrm{P}$ & (Artin) & $\mathrm{P}$ & (Artin) & 290.1 & 279.3 & 10.8 & 0.0 & 10.8 \\
\hline Phacelocrinus & $\mathrm{C}$ & (Tour) & $\mathrm{C}$ & (Bash) & 358.9 & 315.2 & 43.7 & 43.7 & 43.7 \\
\hline Phanocrinus & $\mathrm{C}$ & (Vise) & $\mathrm{C}$ & (Serp) & 346.7 & 323.2 & 23.5 & 23.5 & 23.5 \\
\hline Pirasocrinus & $\mathrm{C}$ & (Mosc) & $\mathrm{C}$ & (Mosc) & 315.2 & 307 & 8.2 & 8.2 & 0.0 \\
\hline Platyfundocrinus & $\mathrm{C}$ & (Mosc) & $\mathrm{C}$ & (Mosc) & 315.2 & 307 & 8.2 & 8.2 & 0.0 \\
\hline Plaxocrinus & $\mathrm{C}$ & (Vise) & $\mathrm{P}$ & (Sakm) & 346.7 & 290.1 & 56.6 & 56.6 & 56.6 \\
\hline Plummericrinus & $\mathrm{C}$ & (Serp) & $\mathrm{P}$ & (Artin) & 330.9 & 279.3 & 51.6 & 51.6 & 51.6 \\
\hline Polusocrinus & $\mathrm{C}$ & (Bash) & $\mathrm{P}$ & (Sakm) & 323.2 & 290.1 & 33.1 & 33.1 & 0.0 \\
\hline Polygonocrinus & $\mathrm{C}$ & (Mosc) & $\mathrm{C}$ & (Step) & 315.2 & 298.9 & 16.3 & 16.3 & 0.0 \\
\hline Poteriocrinites & $\mathrm{D}$ & (Fame) & $\mathrm{C}$ & (Vise) & 372.2 & 330.9 & 41.3 & 0.0 & 41.3 \\
\hline Prininocrinus & $\mathrm{D}$ & (Fras) & $\mathrm{C}$ & (Tour) & 382.7 & 346.7 & 36.0 & 0.0 & 36.0 \\
\hline Proallosocrinus & $\mathrm{C}$ & (Bash) & $\mathrm{C}$ & (Mosc) & 323.2 & 307 & 16.2 & 16.2 & 0.0 \\
\hline Proampelocrinus & $\mathrm{C}$ & (Tour) & $\mathrm{C}$ & (Tour) & 358.9 & 346.7 & 12.2 & 0.0 & 12.2 \\
\hline Probletocrinus & $\mathrm{C}$ & (Step) & $\mathrm{C}$ & (Step) & 307 & 298.9 & 8.1 & 8.1 & 0.0 \\
\hline Proctothylacocrinus & $\mathrm{D}$ & (Give) & $\mathrm{D}$ & (Give) & 387.7 & 382.7 & 5.0 & 0.0 & 5.0 \\
\hline Proindocrinus & $\mathrm{P}$ & (Artin) & $\mathrm{P}$ & (Artin) & 290.1 & 279.3 & 10.8 & 0.0 & 10.8 \\
\hline Prolobocrinus & $\mathrm{P}$ & (Artin) & $\mathrm{P}$ & (Artin) & 290.1 & 279.3 & 10.8 & 0.0 & 10.8 \\
\hline Propoteriocrinus & $\mathrm{D}$ & (Emsi) & $\mathrm{D}$ & (Emsi) & 407.6 & 393.3 & 14.3 & 0.0 & 14.3 \\
\hline Protencrinus & $\mathrm{C}$ & (Mosc) & $\mathrm{P}$ & (Artin) & 315.2 & 279.3 & 35.9 & 35.9 & 35.9 \\
\hline Psilocrinus & $\mathrm{C}$ & (Mosc) & $\mathrm{C}$ & (Mosc) & 315.2 & 307 & 8.2 & 8.2 & 0.0 \\
\hline Pulaskicrinus & $\mathrm{C}$ & (Serp) & $\mathrm{C}$ & (Serp) & 330.9 & 323.2 & 7.7 & 7.7 & 0.0 \\
\hline Pumilindocrinus & $\mathrm{P}$ & (Artin) & $\mathrm{P}$ & (Artin) & 290.1 & 279.3 & 10.8 & 0.0 & 10.8 \\
\hline Pyndaxocrinus & $\mathrm{C}$ & (Step) & $\mathrm{C}$ & (Step) & 307 & 298.9 & 8.1 & 8.1 & 0.0 \\
\hline Ramulocrinus & $\mathrm{C}$ & (Tour) & $\mathrm{C}$ & (Serp) & 358.9 & 323.2 & 35.7 & 35.7 & 35.7 \\
\hline Retusocrinus & $\mathrm{C}$ & (Mosc) & $\mathrm{C}$ & (Step) & 315.2 & 298.9 & 16.3 & 16.3 & 0.0 \\
\hline Rhabdocrinus & $\mathrm{C}$ & (Vise) & $\mathrm{C}$ & (Serp) & 346.7 & 323.2 & 23.5 & 23.5 & 23.5 \\
\hline Rhenocrinus & $\mathrm{D}$ & (Emsi) & $\mathrm{D}$ & (Emsi) & 407.6 & 393.3 & 14.3 & 0.0 & 14.3 \\
\hline Rhopalocrinus & $\mathrm{D}$ & (Eife) & $\mathrm{D}$ & (Eife) & 393.3 & 387.7 & 5.6 & 0.0 & 5.6 \\
\hline Rhopocrinus & $\mathrm{C}$ & (Vise) & $\mathrm{C}$ & (Serp) & 346.7 & 323.2 & 23.5 & 23.5 & 23.5 \\
\hline Rimosindocrinus & $\mathrm{P}$ & (Artin) & $\mathrm{P}$ & (Artin) & 290.1 & 279.3 & 10.8 & 0.0 & 10.8 \\
\hline Roemerocrinus & $\mathrm{P}$ & (Artin) & $\mathrm{P}$ & (Artin) & 290.1 & 279.3 & 10.8 & 0.0 & 10.8 \\
\hline Sardinocrinus & $\mathrm{C}$ & (Mosc) & $\mathrm{C}$ & (Step) & 315.2 & 298.9 & 16.3 & 16.3 & 0.0 \\
\hline Sarocrinus & $\mathrm{C}$ & (Vise) & $\mathrm{C}$ & (Vise) & 346.7 & 330.9 & 15.8 & 0.0 & 15.8 \\
\hline Scammatocrinus & $\mathrm{C}$ & (Vise) & $\mathrm{C}$ & (Serp) & 346.7 & 323.2 & 23.5 & 23.5 & 23.5 \\
\hline Schedexocrinus & $\mathrm{C}$ & (Mosc) & $\mathrm{P}$ & (Sakm) & 315.2 & 290.1 & 25.1 & 25.1 & 0.0 \\
\hline Sciadiocrinus & $\mathrm{C}$ & (Bash) & $\mathrm{C}$ & (Step) & 323.2 & 298.9 & 24.3 & 24.3 & 0.0 \\
\hline Scotiacrinus & $\mathrm{C}$ & (Vise) & $\mathrm{C}$ & (Serp) & 346.7 & 323.2 & 23.5 & 23.5 & 23.5 \\
\hline Scytalocrinus & $\mathrm{D}$ & (Fame) & $\mathrm{C}$ & (Step) & 372.2 & 298.9 & 73.3 & 73.3 & 73.3 \\
\hline Sellardsicrinus & $\mathrm{C}$ & (Bash) & $\mathrm{C}$ & (Mosc) & 323.2 & 307 & 16.2 & 16.2 & 0.0 \\
\hline Separocrinus & $\mathrm{C}$ & (Step) & $\mathrm{C}$ & (Step) & 307 & 298.9 & 8.1 & 8.1 & 0.0 \\
\hline Simocrinus & $\mathrm{C}$ & (Step) & $\mathrm{C}$ & (Step) & 307 & 298.9 & 8.1 & 8.1 & 0.0 \\
\hline Sinocrinus & $\mathrm{C}$ & (Mosc) & $\mathrm{C}$ & (Mosc) & 315.2 & 307 & 8.2 & 8.2 & 0.0 \\
\hline SNOWYCRINUS & $\mathrm{C}$ & (Vise) & $\mathrm{C}$ & (Vise) & 346.7 & 330.9 & 15.8 & 0.0 & 15.8 \\
\hline Sostronocrinus & $\mathrm{D}$ & (Fame) & $\mathrm{C}$ & (Tour) & 372.2 & 346.7 & 25.5 & 0.0 & 25.5 \\
\hline Spaniocrinus & $\mathrm{P}$ & (Artin) & $\mathrm{P}$ & (Artin) & 290.1 & 279.3 & 10.8 & 0.0 & 10.8 \\
\hline Spheniscocrinus & $\mathrm{P}$ & (Artin) & $\mathrm{P}$ & (Artin) & 290.1 & 279.3 & 10.8 & 0.0 & 10.8 \\
\hline Springericrinus & $\mathrm{C}$ & (Tour) & $\mathrm{C}$ & (Vise) & 358.9 & 330.9 & 28.0 & 0.0 & 28.0 \\
\hline Stachyocrinus & $\mathrm{P}$ & (Sakm) & $\mathrm{P}$ & (Word) & 295.5 & 265.1 & 30.4 & 30.4 & 30.4 \\
\hline Staphylocrinus & $\mathrm{C}$ & (Serp) & $\mathrm{C}$ & (Serp) & 330.9 & 323.2 & 7.7 & 7.7 & 0.0 \\
\hline Stellarocrinus & $\mathrm{C}$ & (Mosc) & $\mathrm{P}$ & (Wolf) & 315.2 & 279.3 & 35.9 & 35.9 & 35.9 \\
\hline Stenopecrinus & $\mathrm{C}$ & (Bash) & $\mathrm{P}$ & (Sakm) & 323.2 & 290.1 & 33.1 & 33.1 & 0.0 \\
\hline Stinocrinus & $\mathrm{C}$ & (Vise) & $\mathrm{C}$ & (Vise) & 346.7 & 330.9 & 15.8 & 0.0 & 15.8 \\
\hline
\end{tabular}




\begin{tabular}{|c|c|c|c|c|c|c|c|c|c|}
\hline STREPTOSOCRINUS & $\mathrm{C}$ & (Vise) & $\mathrm{P}$ & (Kung) & 346.7 & 272.3 & 74.4 & 74.4 & 74.4 \\
\hline Strongylocrinus & $\mathrm{C}$ & (Bash) & $\mathrm{P}$ & (Artin) & 323.2 & 279.3 & 43.9 & 43.9 & 43.9 \\
\hline Stuartwellercrinus & $\mathrm{C}$ & (Bash) & $\mathrm{P}$ & (Artin) & 323.2 & 279.3 & 43.9 & 43.9 & 43.9 \\
\hline Subarrectocrinus & $\mathrm{C}$ & (Step) & $\mathrm{P}$ & (Asse) & 307 & 295.5 & 11.5 & 11.5 & 0.0 \\
\hline Sublobalocrinus & $\mathrm{C}$ & (Step) & $\mathrm{C}$ & (Step) & 307 & 298.9 & 8.1 & 8.1 & 0.0 \\
\hline Sundacrinus & $\mathrm{P}$ & (Artin) & $\mathrm{P}$ & (Artin) & 290.1 & 279.3 & 10.8 & 0.0 & 10.8 \\
\hline Synarmocrinus & $\mathrm{C}$ & (Bash) & $\mathrm{C}$ & (Step) & 323.2 & 298.9 & 24.3 & 24.3 & 0.0 \\
\hline Synyphocrinus & $\mathrm{C}$ & (Mosc) & $\mathrm{P}$ & (Artin) & 315.2 & 279.3 & 35.9 & 35.9 & 35.9 \\
\hline Tapinocrinus & $\mathrm{P}$ & (Sakm) & $\mathrm{P}$ & (Artin) & 295.5 & 279.3 & 16.2 & 16.2 & 16.2 \\
\hline Tarachiocrinus & $\mathrm{C}$ & (Mosc) & $\mathrm{C}$ & (Step) & 315.2 & 298.9 & 16.3 & 16.3 & 0.0 \\
\hline TARASSOCRINUS & $\mathrm{D}$ & (Fame) & $\mathrm{D}$ & (Fame) & 372.2 & 358.9 & 13.3 & 0.0 & 13.3 \\
\hline Tasmanocrinus & $\mathrm{P}$ & (Sakm) & $\mathrm{P}$ & (Sakm) & 295.5 & 290.1 & 5.4 & 5.4 & 0.0 \\
\hline Telikosocrinus & $\mathrm{C}$ & (Serp) & $\mathrm{C}$ & (Serp) & 330.9 & 323.2 & 7.7 & 7.7 & 0.0 \\
\hline Terpnocrinus & $\mathrm{C}$ & (Step) & $\mathrm{C}$ & (Step) & 307 & 298.9 & 8.1 & 8.1 & 0.0 \\
\hline Tetrabrachiocrinus & $\mathrm{P}$ & (Word) & $\mathrm{P}$ & (Word) & 268.8 & 265.1 & 3.7 & 0.0 & 3.7 \\
\hline Texacrinus & $\mathrm{C}$ & (Mosc) & $\mathrm{P}$ & (Wuchia) & 315.2 & 254.2 & 61.0 & 61.0 & 61.0 \\
\hline Tholocrinus & $\mathrm{C}$ & (Vise) & $\mathrm{C}$ & (Serp) & 346.7 & 323.2 & 23.5 & 23.5 & 23.5 \\
\hline Trautscholdicrinus & $\mathrm{C}$ & (Mosc) & $\mathrm{C}$ & (Mosc) & 315.2 & 307 & 8.2 & 8.2 & 0.0 \\
\hline Tribrachyocrinus & $\mathrm{P}$ & (Artin) & $\mathrm{P}$ & (Word) & 290.1 & 265.1 & 25.0 & 0.0 & 25.0 \\
\hline Triceracrinus & $\mathrm{C}$ & (Mosc) & $\mathrm{P}$ & (Wolf) & 315.2 & 279.3 & 35.9 & 35.9 & 35.9 \\
\hline Trimerocrinus & $\mathrm{P}$ & (Artin) & $\mathrm{P}$ & (Artin) & 290.1 & 279.3 & 10.8 & 0.0 & 10.8 \\
\hline Tundracrinus & $\mathrm{C}$ & (Mosc) & $\mathrm{P}$ & (Artin) & 315.2 & 279.3 & 35.9 & 35.9 & 35.9 \\
\hline Tyrieocrinus & $\mathrm{C}$ & (Vise) & $\mathrm{C}$ & (Serp) & 346.7 & 323.2 & 23.5 & 23.5 & 23.5 \\
\hline Ulocrinus & $\mathrm{C}$ & (Mosc) & $\mathrm{C}$ & (Step) & 315.2 & 298.9 & 16.3 & 16.3 & 0.0 \\
\hline Ulrichicrinus & $\mathrm{C}$ & (Vise) & $\mathrm{C}$ & (Mosc) & 346.7 & 307 & 39.7 & 39.7 & 39.7 \\
\hline Ureocrinus & $\mathrm{C}$ & (Vise) & $\mathrm{C}$ & (Serp) & 346.7 & 323.2 & 23.5 & 23.5 & 23.5 \\
\hline Utharocrinus & $\mathrm{C}$ & (Bash) & $\mathrm{P}$ & (Sakm) & 323.2 & 290.1 & 33.1 & 33.1 & 0.0 \\
\hline Vertigocrinus & $\mathrm{C}$ & (Mosc) & $\mathrm{C}$ & (Step) & 315.2 & 298.9 & 16.3 & 16.3 & 0.0 \\
\hline Wetherbyocrinus & $\mathrm{C}$ & (Serp) & $\mathrm{C}$ & (Serp) & 330.9 & 323.2 & 7.7 & 7.7 & 0.0 \\
\hline Woodocrinus & $\mathrm{C}$ & (Vise) & $\mathrm{C}$ & (Serp) & 346.7 & 323.2 & 23.5 & 23.5 & 23.5 \\
\hline Worthenocrinus & $\mathrm{C}$ & (Vise) & $\mathrm{C}$ & (Vise) & 346.7 & 330.9 & 15.8 & 0.0 & 15.8 \\
\hline Yakovlevicrinus & $\mathrm{P}$ & (Artin) & $\mathrm{P}$ & (Artin) & 290.1 & 279.3 & 10.8 & 0.0 & 10.8 \\
\hline Zeacrinites & $\mathrm{C}$ & (Vise) & $\mathrm{C}$ & (Serp) & 346.7 & 323.2 & 23.5 & 23.5 & 23.5 \\
\hline Zeusocrinus & $\mathrm{C}$ & (Serp) & $\mathrm{C}$ & (Serp) & 330.9 & 323.2 & 7.7 & 7.7 & 0.0 \\
\hline Zostocrinus & $\mathrm{D}$ & (Give) & $\mathrm{D}$ & (Give) & 387.7 & 382.7 & 5.0 & 0.0 & 5.0 \\
\hline & & & & & \multicolumn{2}{|c|}{ Average Duration: } & 21.1 & 24.3 & 23.9 \\
\hline & & & & & \multicolumn{2}{|c|}{ Median: } & 16.2 & 23.5 & 19.6 \\
\hline & & & & & \multicolumn{2}{|c|}{$\mathbf{N}($ Sample) } & 315 & 191 & 208 \\
\hline \multicolumn{10}{|l|}{ Or. TAXOCRINIDA } \\
\hline Enascocrinus & $\mathrm{C}$ & (Vise) & $\mathrm{C}$ & (Vise) & 346.7 & 330.9 & 15.8 & 0.0 & 15.8 \\
\hline Euonychocrinus & $\mathrm{D}$ & (Fame) & $\mathrm{C}$ & (Step) & 372.2 & 298.9 & 73.3 & 73.3 & 73.3 \\
\hline Eutaxocrinus & S & (Wenl) & $\mathrm{C}$ & (Tour) & 433.4 & 346.7 & 86.7 & 0.0 & 86.7 \\
\hline Meristocrinus & $\mathrm{S}$ & (Wenl) & $\mathrm{C}$ & (Tour) & 433.4 & 346.7 & 86.7 & 0.0 & 86.7 \\
\hline Onychocrinus & $\mathrm{C}$ & (Tour) & $\mathrm{C}$ & (Serp) & 358.9 & 323.2 & 35.7 & 35.7 & 35.7 \\
\hline Parichthyocrinus & $\mathrm{C}$ & (Tour) & $\mathrm{C}$ & (Vise) & 358.9 & 330.9 & 28.0 & 0.0 & 28.0 \\
\hline Protaxocrinus & $\mathrm{O}$ & (Cara) & $\mathrm{D}$ & (Loch) & 460.9 & 410.8 & 50.1 & 0.0 & 50.1 \\
\hline Synerocrinus & $\mathrm{C}$ & (Serp) & $\mathrm{C}$ & (Mosc) & 330.9 & 307 & 23.9 & 23.9 & 0.0 \\
\hline \multirow[t]{4}{*}{ Taxocrinus } & $\mathrm{D}$ & (Eife) & $\mathrm{C}$ & (Serp) & 393.3 & 323.2 & 70.1 & 70.1 & 70.1 \\
\hline & & & & & \multicolumn{2}{|c|}{ Average Duration: } & 52.3 & 50.8 & 53.5 \\
\hline & & & & & \multicolumn{2}{|c|}{ Median: } & 50.1 & 52.9 & 50.1 \\
\hline & & & & & \multicolumn{2}{|c|}{ N(Sample) } & 9 & 4 & 8 \\
\hline \multicolumn{10}{|l|}{ Or. SAGENOCRINIDA } \\
\hline Aexitrophocrinus & $\mathrm{C}$ & (Vise) & $\mathrm{C}$ & (Step) & 346.7 & 298.9 & 47.8 & 47.8 & 47.8 \\
\hline
\end{tabular}




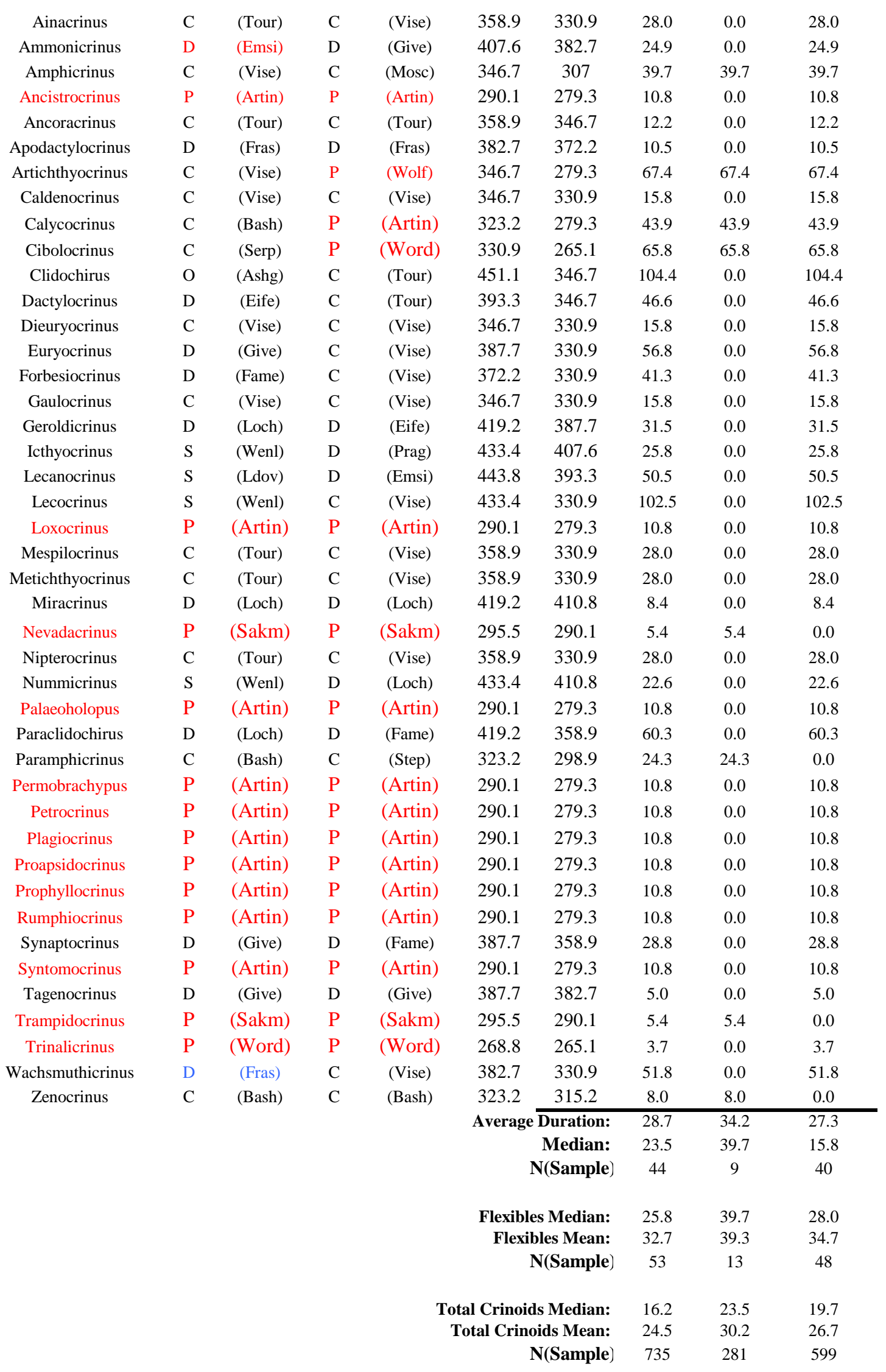




\section{APPENDIX(Cont.): Converted Data (Absence/Presence)}

Paleozoic crinoid FAD/LAD data converted to presence/absence data. Crinoid genera are assumed to be present from FAD to LAD. Highlighted totals represent the time interval studied and the numbers 1-30 represent the time bins assigned to stages. Time bin one is the Tremadocian (485.4 Ma), and time bin 30 is the Wuchiapingian (259.8 Ma). All ranges were minimized where uncertain. Red, Blue, and Green text are updated/added in 2014/2015. Red text represents Permian range revisions from Webster, 2015. Green text represents revisions made from Rhenberg et al., 2015. This data was used to calculate the stratigraphic range values from Foote and Miller (2007).

\begin{tabular}{|c|c|c|c|c|c|c|c|c|c|c|c|c|c|c|c|c|c|c|c|c|c|c|c|c|c|c|c|c|c|c|c|c|}
\hline & First & Last & $\mathbf{1}$ & 2 & 3 & 4 & 5 & 6 & 7 & 8 & 9 & 10 & 11 & 12 & 13 & 14 & 15 & 16 & 17 & 181 & 191 & 20 & 21 & 22 & 23 & 24 & 25 & 26 & 27 & 28 & 29 & 30 \\
\hline \multicolumn{33}{|l|}{ Cl. CRINOIDEA } \\
\hline & & & & & & & & & & & & & & & & & & & & & & & & & & & & & & & & \\
\hline \multicolumn{33}{|l|}{ Or. DIPLOBATHRIDA } \\
\hline Acanthocrinus & 13 & 15 & & & & & & & & & & & & & 1 & 1 & 1 & & & & & & & & & & & & & & & \\
\hline Ambicocrinus & 11 & & & & & & & & & & & & 1 & & & & & & & & & & & & & & & & & & & \\
\hline Apurocrinus & 13 & & & & & & & & & & & & & & 1 & & & & & & & & & & & & & & & & & \\
\hline Cadisocrinus & 15 & & & & & & & & & & & & & & & & 1 & & & & & & & & & & & & & & & \\
\hline Condylocrinus & 14 & & & & & & & & & & & & & & & 1 & & & & & & & & & & & & & & & & \\
\hline Cribanocrinus & 18 & 19 & & & & & & & & & & & & & & & & & & 1 & 1 & & & & & & & & & & & \\
\hline Diamenocrinus & 11 & 13 & & & & & & & & & & & 1 & 1 & 1 & & & & & & & & & & & & & & & & & \\
\hline Dimerocrinites & 7 & 15 & & & & & & & 1 & 1 & 1 & 1 & 1 & 1 & 1 & 1 & 1 & & & & & & & & & & & & & & & \\
\hline DUNCANICRINUS & 11 & & & & & & & & & & & & 1 & & & & & & & & & & & & & & & & & & & \\
\hline EUCRINUS & 8 & 11 & & & & & & & & 1 & 1 & 1 & 1 & & & & & & & & & & & & & & & & & & & \\
\hline Eudimerocrinus & 9 & 11 & & & & & & & & & 1 & 1 & 1 & & & & & & & & & & & & & & & & & & & \\
\hline Gilbertsocrinus & 15 & 19 & & & & & & & & & & & & & & & 1 & 1 & 1 & 1 & 1 & & & & & & & & & & & \\
\hline Griphocrinus & 14 & 15 & & & & & & & & & & & & & & 1 & 1 & & & & & & & & & & & & & & & \\
\hline HOLLOWAYCRINUS & 11 & & & & & & & & & & & & 1 & & & & & & & & & & & & & & & & & & & \\
\hline Lemennocrinus & 14 & & & & & & & & & & & & & & & 1 & & & & & & & & & & & & & & & & \\
\hline Macarocrinus & 13 & & & & & & & & & & & & & & 1 & & & & & & & & & & & & & & & & & \\
\hline Monstrocrinus & 13 & 14 & & & & & & & & & & & & & 1 & & & & & & & & & & & & & & & & & \\
\hline Neoarchaeocrinus & 5 & 12 & & & & & 1 & 1 & 1 & 1 & 1 & 1 & 1 & 1 & & & & & & & & & & & & & & & & & & \\
\hline Nexocrinus & 7 & 11 & & & & & & & 1 & 1 & 1 & 1 & 1 & & & & & & & & & & & & & & & & & & & \\
\hline Ophiocrinus & 11 & 13 & & & & & & & & & & & 1 & 1 & 1 & & & & & & & & & & & & & & & & & \\
\hline Opsiocrinus & 15 & & & & & & & & & & & & & & & & 1 & & & & & & & & & & & & & & & \\
\hline Orthocrinus & 12 & 14 & & & & & & & & & & & & 1 & 1 & 1 & & & & & & & & & & & & & & & & \\
\hline
\end{tabular}




\begin{tabular}{|c|c|c|c|c|c|c|c|c|c|c|c|c|c|c|c|c|c|c|c|c|c|c|c|c|c|c|c|c|c|c|c|c|}
\hline Perunocrinus & 12 & 13 & & & & & & & & & & & & 1 & 1 & & & & & & & & & & & & & & & & & \\
\hline Pterinocrinus & 13 & 16 & & & & & & & & & & & & & 1 & 1 & 1 & 1 & 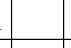 & & & & & & & & & & & & & \\
\hline Rhipidocrinus & 14 & 17 & & & & & & & & & & & & & & 1 & 1 & 1 & 1 & & & & & & & & & & & & & \\
\hline Rhodocrinites & 12 & 20 & & & & & & & & & & & & 1 & 1 & 1 & 1 & 1 & 1 & 1 & 1 & 1 & & & & & & & & & & \\
\hline Shidianocrinus & 15 & & & & & & & & & & & & & & & & 1 & & & & & & & & & & & & & & & \\
\hline Sphaerotocrinus & 11 & & & & & & & & & & & & 1 & & & & & & & & & & & & & & & & & & & \\
\hline Spyridiocrinus & 12 & 13 & & & & & & & & & & & & 1 & 1 & & & & & & & & & & & & & & & & & \\
\hline Thylacocrinus & 12 & 15 & & & & & & & & & & & & 1 & 1 & 1 & 1 & & & & & & & & & & & & & & & \\
\hline & & & & & & & & & & & & & & & & & & & & & & & & & & & & & & & & \\
\hline $\begin{array}{c}\text { DIPLOBATHRID } \\
\text { TOTALS } \\
\end{array}$ & & & 0 & 0 & 0 & 0 & 1 & 1 & 3 & 4 & 5 & 5 & 11 & 9 & 13 & 10 & 11 & 4 & 3 & 3 & 3 & 1 & 0 & 0 & 0 & 0 & 0 & 0 & 0 & 0 & 0 & 0 \\
\hline & & & 1 & 2 & 3 & 4 & 5 & 6 & 7 & 8 & 9 & 10 & 11 & 12 & 13 & 14 & 15 & 16 & 17 & 18 & 19 & 20 & 21 & 22 & 23 & 24 & 25 & 26 & 27 & 28 & 29 & 30 \\
\hline & & & & & & & & & & & & & & & & & & & & & & & & & & & & & & & & \\
\hline Or. MONOBATHRID & & & & & & & & & & & & & & & & & & & & & & & & & & & & & & & & \\
\hline Aacocrinus & 18 & 21 & & & & & & & & & & & & & & & & & & 1 & 1 & 1 & 1 & & & & & & & & & \\
\hline Abactinocrinus & 17 & 18 & & & & & & & & & & & & & & & & & 1 & 1 & & & & & & & & & & & & \\
\hline Abatocrinus & 18 & 19 & & & & & & & & & & & & & & & & & & 1 & 1 & & & & & & & & & & & \\
\hline Acacocrinus & 7 & 15 & & & & & & & 1 & 1 & 1 & 1 & 1 & 1 & 1 & 1 & 1 & & & & & & & & & & & & & & & \\
\hline Acrocrinus & 19 & 20 & & & & & & & & & & & & & & & & & & & 1 & 1 & & & & & & & & & & \\
\hline Actinocrinites & 18 & 26 & & & & & & & & & & & & & & & & & & 1 & 1 & 1 & 1 & 1 & 1 & 1 & 1 & 1 & & & & \\
\hline ADELOCRINUS & 17 & & & & & & & & & & & & & & & & & & 1 & & & & & & & & & & & & & \\
\hline Agaricocrinus & 18 & 19 & & & & & & & & & & & & & & & & & & 1 & 1 & & & & & & & & & & & \\
\hline Agathocrinus & $13 ?$ & 17 & & & & & & & & & & & & & 1 & 1 & 1 & 1 & 1 & & & & & & & & & & & & & \\
\hline Alloprosallocrinus & 19 & & & & & & & & & & & & & & & & & & & & 1 & & & & & & & & & & & \\
\hline Amonohexacrinus & $13 ?$ & & & & & & & & & & & & & & 1 & & & & & & & & & & & & & & & & & \\
\hline Amphoracrinus & 18 & 19 & & & & & & & & & & & & & & & & & & 1 & 1 & & & & & & & & & & & \\
\hline Amphoracrocrinus & 19 & $20 ?$ & & & & & & & & & & & & & & & & & & & 1 & 1 & & & & & & & & & & \\
\hline Ancalocrinus & 18 & 18 & & & & & & & & & & & & & & & & & & 1 & & & & & & & & & & & & \\
\hline Aorocrinus & 15 & 19 & & & & & & & & & & & & & & & 1 & 1 & 1 & 1 & 1 & & & & & & & & & & & \\
\hline Arthroacantha & 13 & $16 ?$ & & & & & & & & & & & & & 1 & 1 & 1 & 1 & 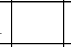 & & & & & & & & & & & & & \\
\hline Aryballocrinus & 18 & 19 & & & & & & & & & & & & & & & & & & 1 & 1 & & & & & & & & & & & \\
\hline Athabascacrinus & 17 & 18 & & & & & & & & & & & & & & & & & 1 & 1 & & & & & & & & & & & & \\
\hline AULINOCRINUS & 12 & & & & & & & & & & & & & 1 & & & & & & & & & & & & & & & & & & \\
\hline Auliskocrinus & 19 & 28 & & & & & & & & & & & & & & & & & & & 1 & 1 & 1 & 1 & 1 & 1 & 1 & 1 & 1 & 1 & & \\
\hline Azygocrinus & 18 & & & & & & & & & & & & & & & & & & & 1 & & & & & & & & & & & & \\
\hline Batocrinus & 19 & 19 & & & & & & & & & & & & & & & & & & & 1 & & & & & & & & & & & \\
\hline Beyrichocrinus & 12 & & & & & & & & & & & & & 1 & & & & & & & & & & & & & & & & & & \\
\hline Blairocrinus & 18 & & & & & & & & & & & & & & & & & & & 1 & & & & & & & & & & & & \\
\hline
\end{tabular}




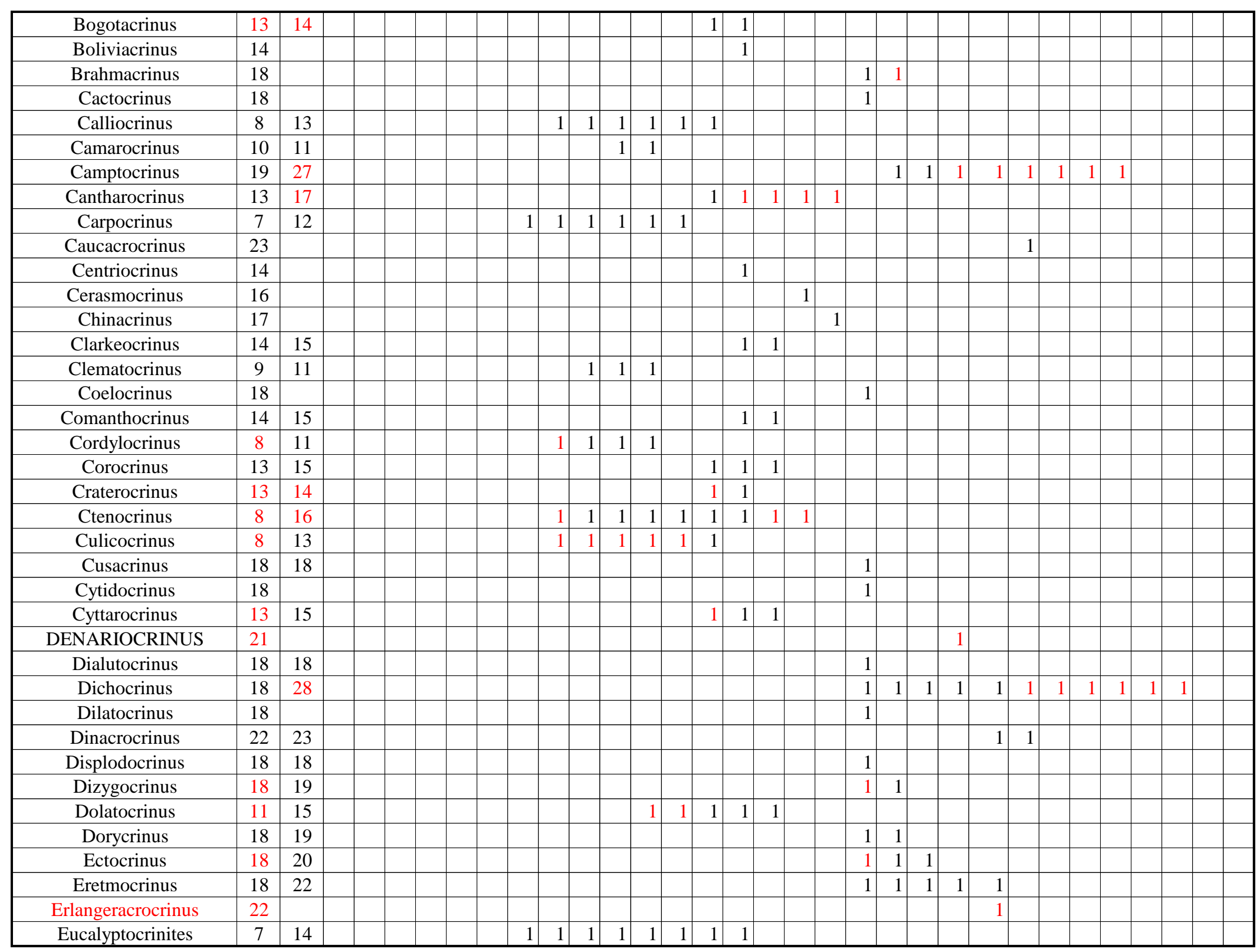




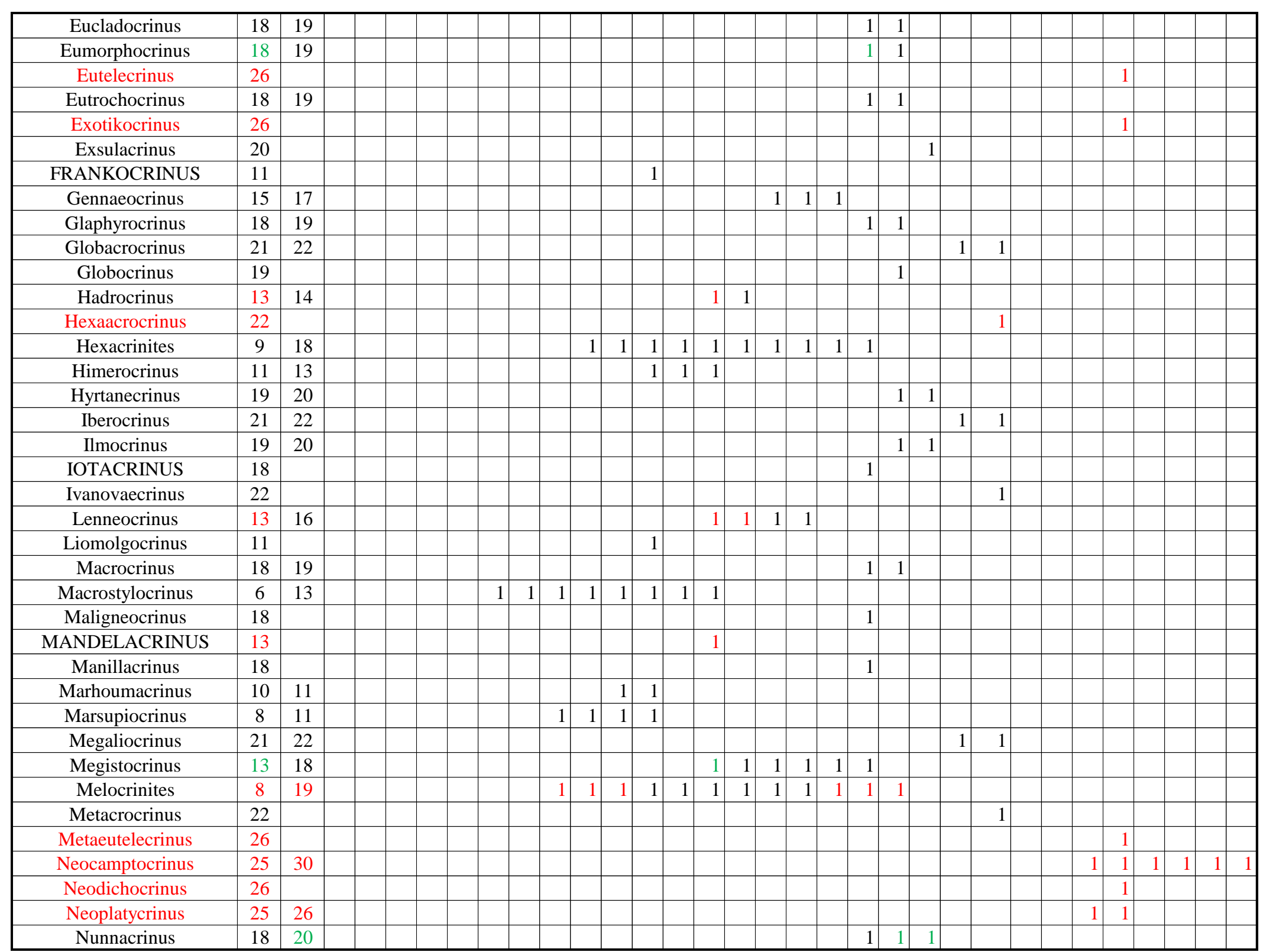




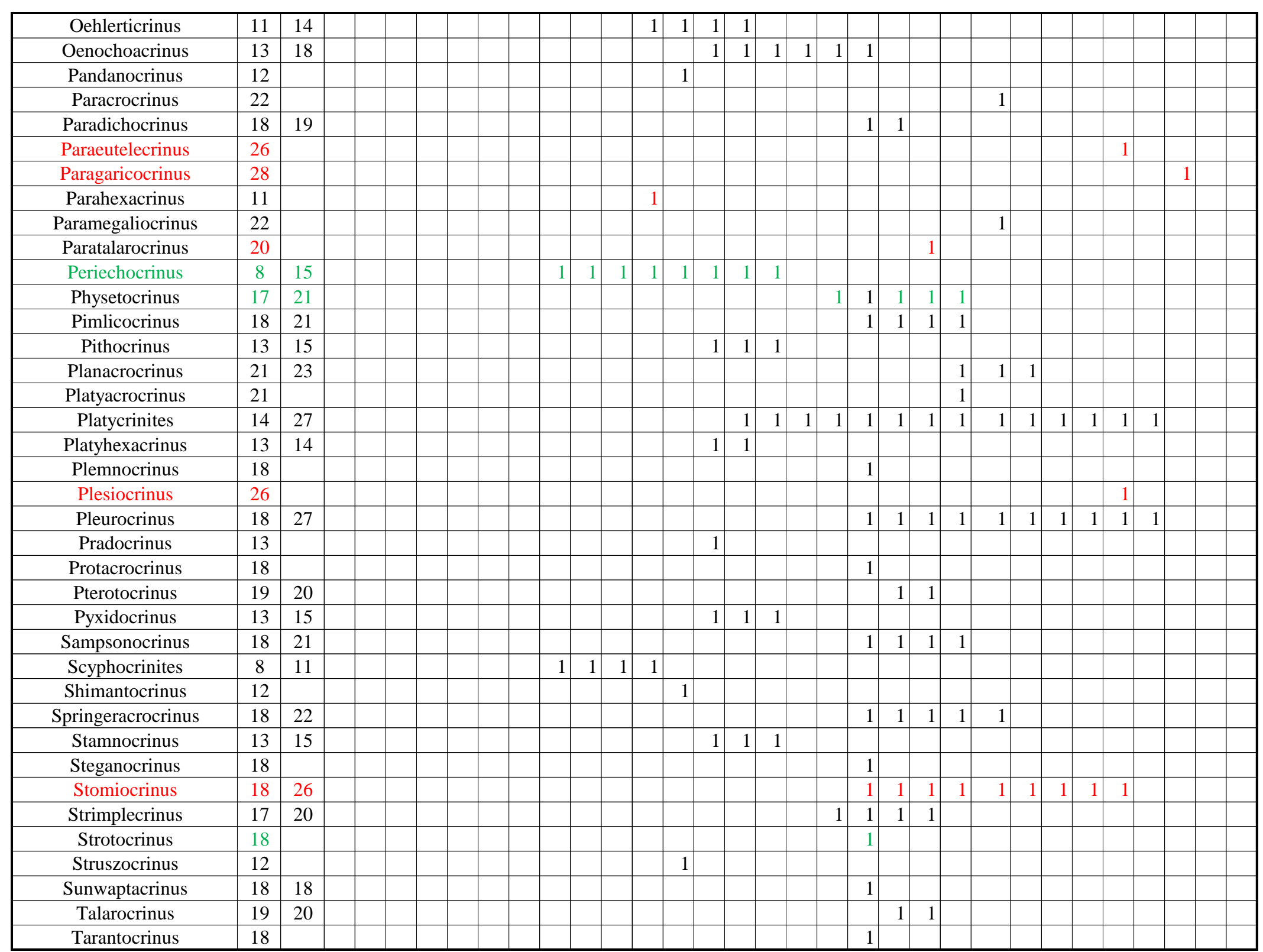




\begin{tabular}{|c|c|c|c|c|c|c|c|c|c|c|c|c|c|c|c|c|c|c|c|c|c|c|c|c|c|c|c|c|c|c|c|c|}
\hline Technocrinus & 9 & 12 & & & & & & & & & 1 & 1 & 1 & 1 & & & & & & & & & & & & & & & & & & \\
\hline Teleiocrinus & 18 & & & & & & & & & & & & & & & & & & & 1 & & & & & & & & & & & & \\
\hline Thallocrinus & 13 & & & & & & & & & & & & & & 1 & & & & & & & & & & & & & & & & & \\
\hline Thamnocrinus & 15 & & & & & & & & & & & & & & & & 1 & & & & & & & & & & & & & & & \\
\hline THINOCRINUS & 18 & 26 & & & & & & & & & & & & & & & & & & 1 & 1 & 1 & 1 & 1 & 1 & 1 & 1 & 1 & & & & \\
\hline Timocrinus & 13 & & & & & & & & & & & & & & 1 & & & & & & & & & & & & & & & & & \\
\hline Timorechinus & 26 & & & & & & & & & & & & & & & & & & & & & & & & & & & 1 & & & & \\
\hline Timorocidaris & 26 & & & & & & & & & & & & & & & & & & & & & & & & & & & 1 & & & & \\
\hline Trichotocrinus & 16 & & & & & & & & & & & & & & & & & 1 & & & & & & & & & & & & & & \\
\hline Trybliocrinus & 12 & 14 & & & & & & & & & & & & 1 & 1 & 1 & & & & & & & & & & & & & & & & \\
\hline Tunisiacrinus & 28 & & & & & & & & & & & & & & & & & & & & & & & & & & & & & 1 & & \\
\hline Uperocrinus & 17 & 19 & & & & & & & & & & & & & & & & & 1 & 1 & 1 & & & & & & & & & & & \\
\hline WACRINUS & 17 & & & & & & & & & & & & & & & & & & 1 & & & & & & & & & & & & & \\
\hline Wannerocrinus & 26 & & & & & & & & & & & & & & & & & & & & & & & & & & & 1 & & & & \\
\hline & & & & & & & & & & & & & & & & & & & & & & & & & & & & & & & & \\
\hline CAMERATE TOTAL & & & 1 & 2 & 3 & 4 & 7 & 9 & 17 & 28 & 34 & 37 & 56 & 50 & 72 & 63 & 60 & 38 & 40 & 80 & 67 & 47 & 41 & 43 & 34 & 32 & 35 & 44 & 32 & 33 & 30 & 31 \\
\hline & & & 1 & 2 & 3 & 4 & 5 & 6 & 7 & 8 & 9 & 10 & 11 & 12 & 13 & 14 & 15 & 16 & 17 & 18 & 19 & 20 & 21 & 22 & 23 & 24 & 25 & 26 & 27 & 28 & 29 & 30 \\
\hline & & & & & & & & & & & & & & & & & & & & & & & & & & & & & & & & \\
\hline Or. DISPARIDA & & & & & & & & & & & & & & & & & & & & & & & & & & & & & & & & \\
\hline Allagecrinus & 17 & 20 & & & & & & & & & & & & & & & & & 1 & 1 & 1 & 1 & & & & & & & & & & \\
\hline Allocatillocrinus & 19 & 26 & & & & & & & & & & & & & & & & & & & 1 & 1 & 1 & 1 & 1 & 1 & 1 & 1 & & & & \\
\hline Anamesocrinus & 15 & 17 & & & & & & & & & & & & & & & 1 & 1 & 1 & & & & & & & & & & & & & \\
\hline Aureocrinus & 12 & & & & & & & & & & & & & 1 & & & & & & & & & & & & & & & & & & \\
\hline Belemnocrinus & 18 & 19 & & & & & & & & & & & & & & & & & & 1 & 1 & & & & & & & & & & & \\
\hline BELSKAYACRINUS & 22 & & & & & & & & & & & & & & & & & & & & & & & 1 & & & & & & & & \\
\hline Brachiocrinus & 11 & & & & & & & & & & & & 1 & & & & & & & & & & & & & & & & & & & \\
\hline Calycanthocrinus & 13 & 17 & & & & & & & & & & & & & 1 & 1 & 1 & 1 & 1 & & & & & & & & & & & & & \\
\hline Catillocrinus & 18 & 21 & & & & & & & & & & & & & & & & & & 1 & 1 & 1 & 1 & & & & & & & & & \\
\hline Changninocrinus & $14-15$ & & & & & & & & & & & & & & & 1 & & & & & & & & & & & & & & & & \\
\hline Cunctocrinus & 15 & & & & & & & & & & & & & & & & 1 & & & & & & & & & & & & & & & \\
\hline DARRAGHCRINUS & 11 & & & & & & & & & & & & 1 & & & & & & & & & & & & & & & & & & & \\
\hline Desmacriocrinus & 17 & 18 & & & & & & & & & & & & & & & & & 1 & 1 & & & & & & & & & & & & \\
\hline Dolerocrinus & 14 & & & & & & & & & & & & & & & 1 & & & & & & & & & & & & & & & & \\
\hline Eohalysiocrinus & 8 & 14 & & & & & & & & 1 & 1 & 1 & 1 & 1 & 1 & 1 & & & & & & & & & & & & & & & & \\
\hline Eopilidiocrinus & 26 & & & & & & & & & & & & & & & & & & & & & & & & & & & 1 & & & & \\
\hline Epihalysiocrinus & 21 & 26 & & & & & & & & & & & & & & & & & & & & & 1 & 1 & 1 & 1 & 1 & 1 & & & & \\
\hline Espanocrinus & 13 & & & & & & & & & & & & & & 1 & & & & & & & & & & & & & & & & & \\
\hline Eucatillocrinus & 19 & 21 & & & & & & & & & & & & & & & & & & & 1 & 1 & 1 & & & & & & & & & \\
\hline
\end{tabular}




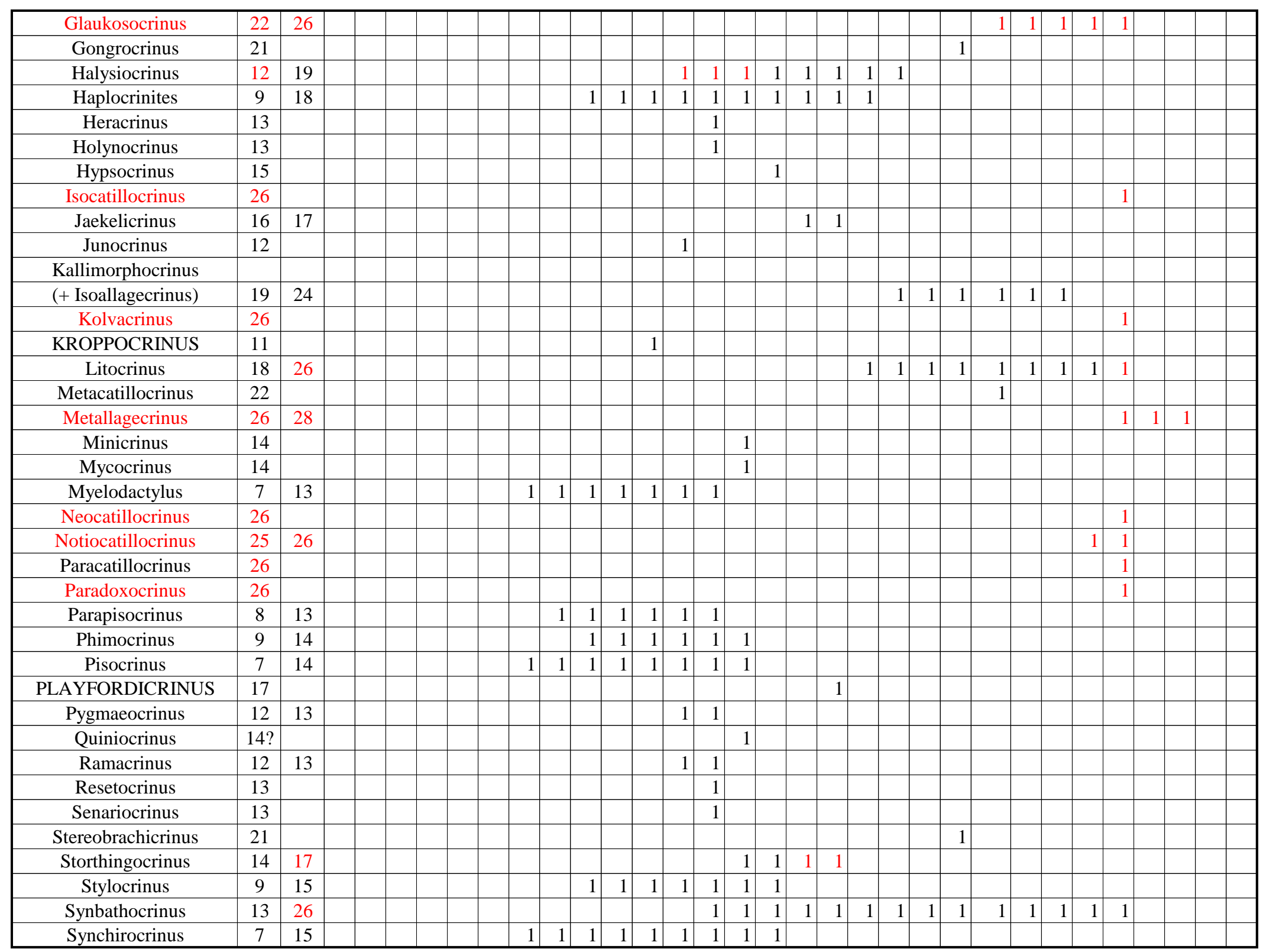




\begin{tabular}{|c|c|c|c|c|c|c|c|c|c|c|c|c|c|c|c|c|c|c|c|c|c|c|c|c|c|c|c|c|c|c|c|c|}
\hline Taidocrinus & 20 & 27 & & & & & & & & & & & & & & & & & & & & 1 & 1 & 1 & 1 & 1 & 1 & 1 & 1 & & & \\
\hline Thaminocrinus & 19 & & & & & & & & & & & & & & & & & & & & 1 & & & & & & & & & & & \\
\hline Theloreus & 11 & 12 & & & & & & & & & & & 1 & 1 & & & & & & & & & & & & & & & & & & \\
\hline Tiaracrinus & 11 & 14 & & & & & & & & & & & 1 & 1 & 1 & 1 & & & & & & & & & & & & & & & & \\
\hline Triacrinus & 9 & 17 & & & & & & & & & 1 & 1 & 1 & 1 & 1 & 1 & 1 & 1 & 1 & & & & & & & & & & & & & \\
\hline Trichocrinus & 9 & 14 & & & & & & & & & 1 & 1 & 1 & 1 & 1 & 1 & & & & & & & & & & & & & & & & \\
\hline Trophocrinus & 18 & 21 & & & & & & & & & & & & & & & & & & 1 & 1 & 1 & 1 & & & & & & & & & \\
\hline Ufacrinus & 26 & & & & & & & & & & & & & & & & & & & & & & & & & & & 1 & & & & \\
\hline Whiteocrinus & 18 & & & & & & & & & & & & & & & & & & & 1 & & & & & & & & & & & & \\
\hline Wrightocrinus & 25 & 26 & & & & & & & & & & & & & & & & & & & & & & & & & 1 & 1 & & & & \\
\hline Xenocatillocrinus & 26 & & & & & & & & & & & & & & & & & & & & & & & & & & & 1 & & & & \\
\hline Xisoallogecrinus & 22 & 24 & & & & & & & & & & & & & & & & & & & & & & 1 & 1 & 1 & & & & & & \\
\hline DISPARID TOTALS & & & 0 & 0 & 0 & 0 & 0 & 0 & 3 & 5 & 10 & 10 & 15 & 17 & 21 & 18 & 11 & 8 & 11 & 10 & 11 & 9 & 11 & 10 & 8 & 8 & 8 & 17 & 2 & 1 & 0 & 0 \\
\hline & & & $\mathbf{1}$ & 2 & 3 & 4 & 5 & 6 & 7 & 8 & 9 & 10 & 11 & 12 & 13 & 14 & 15 & 16 & 17 & 18 & 19 & 20 & 21 & 22 & 23 & 24 & 25 & 26 & 27 & 28 & 29 & 30 \\
\hline & & & & & & & & & & & & & & & & & & & & & & & & & & & & & & & & \\
\hline Or. CLADIDA & & & & & & & & & & & & & & & & & & & & & & & & & & & & & & & & \\
\hline PRIMITIVE CLADIDS & & & & & & & & & & & & & & & & & & & & & & & & & & & & & & & & \\
\hline Abrachiocrinus & 19 & 26 & & & & & & & & & & & & & & & & & & & 1 & 1 & 1 & 1 & 1 & 1 & 1 & 1 & & & & \\
\hline Acariaiocrinus & 26 & & & & & & & & & & & & & & & & & & & & & & & & & & & 1 & & & & \\
\hline Achradocrinus & 14 & & & & & & & & & & & & & & & 1 & & & & & & & & & & & & & & & & \\
\hline Allosycocrinus & 26 & & & & & & & & & & & & & & & & & & & & & & & & & & & 1 & & & & \\
\hline Alsopocrinus & 11 & & & & & & & & & & & & 1 & & & & & & & & & & & & & & & & & & & \\
\hline Amphipsalidocrinus & 15 & 26 & & & & & & & & & & & & & & & 1 & 1 & 1 & 1 & 1 & 1 & 1 & 1 & 1 & 1 & 1 & 1 & & & & \\
\hline Anaglyptocrinus & 26 & & & & & & & & & & & & & & & & & & & & & & & & & & & 1 & & & & \\
\hline Ancyrocrinus & 12 & 15 & & & & & & & & & & & & 1 & 1 & 1 & 1 & & & & & & & & & & & & & & & \\
\hline Antihomocrinus & 9 & 13 & & & & & & & & & 1 & 1 & 1 & 1 & 1 & & & & & & & & & & & & & & & & & \\
\hline Arachnocrinus & 13 & 14 & & & & & & & & & & & & & 1 & 1 & & & & & & & & & & & & & & & & \\
\hline Asymmetrocrinus & 26 & & & & & & & & & & & & & & & & & & & & & & & & & & & 1 & & & & \\
\hline Atelestocrinus & 18 & & & & & & & & & & & & & & & & & & & 1 & & & & & & & & & & & & \\
\hline Atractocrinus & 14 & 15 & & & & & & & & & & & & & & 1 & 1 & & & & & & & & & & & & & & & \\
\hline Atremacrinus & 26 & & & & & & & & & & & & & & & & & & & & & & & & & & & 1 & & & & \\
\hline Aulodesocrinus & 19 & & & & & & & & & & & & & & & & & & & & 1 & & & & & & & & & & & \\
\hline Bactrocrinites & 9 & 15 & & & & & & & & & 1 & 1 & 1 & 1 & 1 & 1 & 1 & & & & & & & & & & & & & & & \\
\hline Barycrinus & 18 & 19 & & & & & & & & & & & & & & & & & & 1 & 1 & & & & & & & & & & & \\
\hline Belanskicrinus & 16 & & & & & & & & & & & & & & & & & 1 & & & & & & & & & & & & & & \\
\hline Bolbocrinus & 26 & & & & & & & & & & & & & & & & & & & & & & & & & & & 1 & & & & \\
\hline Botryocrinus & 8 & 15 & & & & & & & & 1 & 1 & 1 & 1 & 1 & 1 & 1 & 1 & & & & & & & & & & & & & & & \\
\hline
\end{tabular}




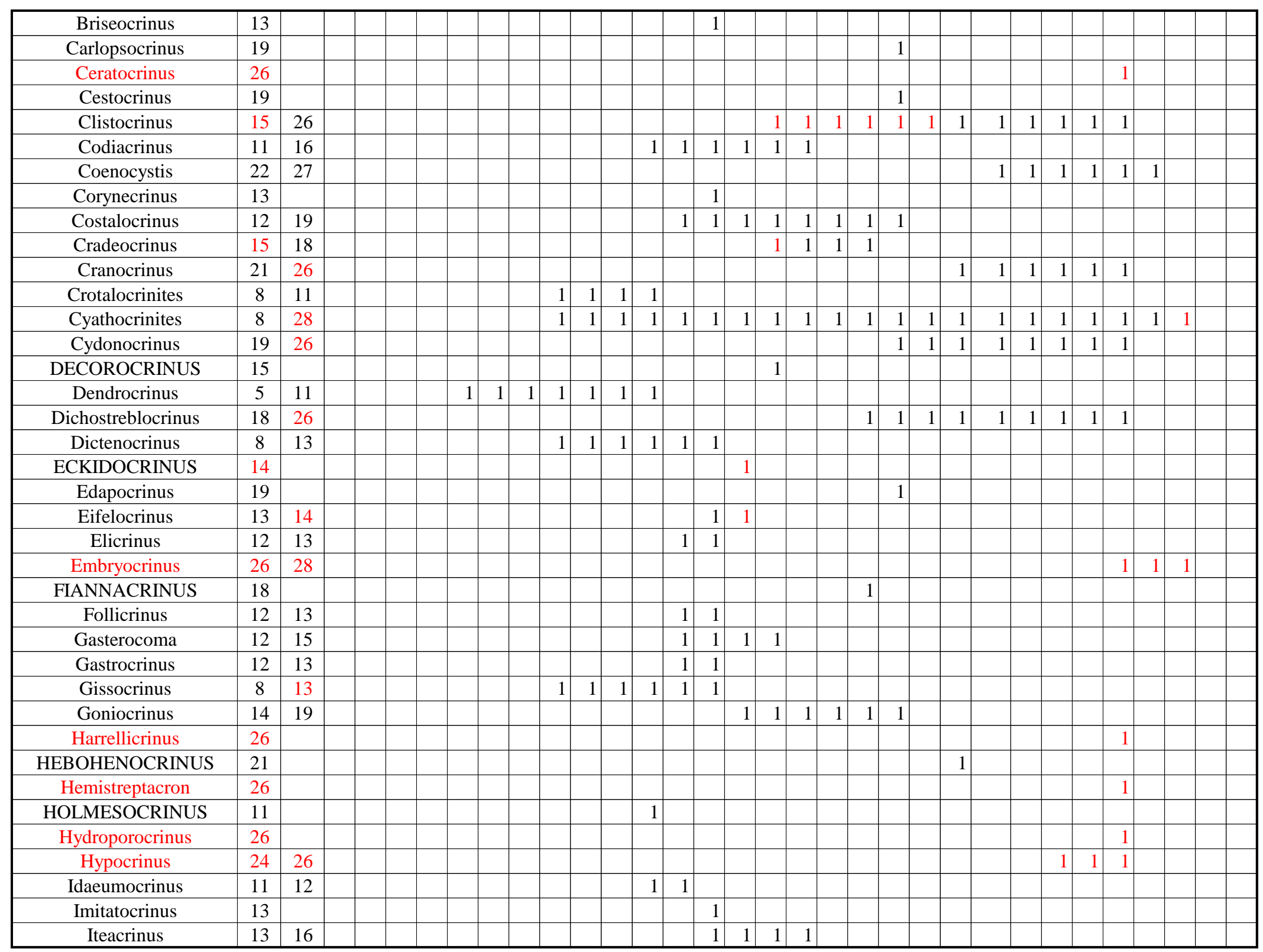




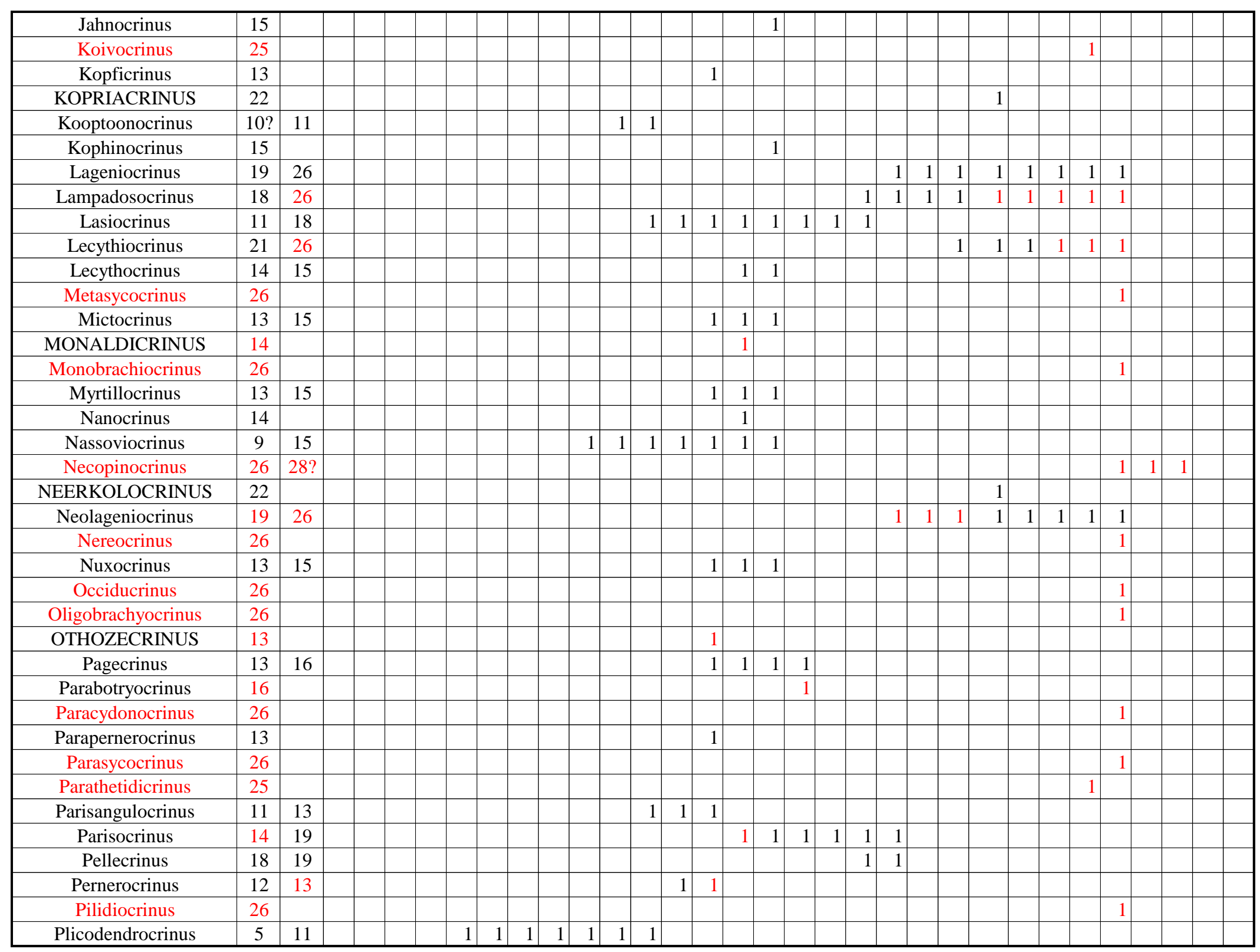




\begin{tabular}{|c|c|c|c|c|c|c|c|c|c|c|c|c|c|c|c|c|c|c|c|c|c|c|c|c|c|c|c|c|c|c|c|c|}
\hline Prochoidiocrinus & 26 & & & & & & & & & & & & & & & & & & & & & & & & & & & 1 & & & & \\
\hline Pskovicrinus & 16 & & & & & & & & & & & & & & & & & 1 & & & & & & & & & & & & & & \\
\hline Pyrenocrinus & 13 & 15 & & & & & & & & & & & & & 1 & 1 & 1 & & & & & & & & & & & & & & & \\
\hline Quantoxocrinus & 15 & 17 & & & & & & & & & & & & & & & 1 & 1 & 1 & & & & & & & & & & & & & \\
\hline Rhadinocrinus & 13 & 15 & & & & & & & & & & & & & 1 & 1 & 1 & & & & & & & & & & & & & & & \\
\hline RUTKOWSKICRINUS & 15 & & & & & & & & & & & & & & & & 1 & & & & & & & & & & & & & & & \\
\hline Saccosompsis & 19 & & & & & & & & & & & & & & & & & & & & 1 & & & & & & & & & & & \\
\hline SACRINUS & 13 & 14 & & & & & & & & & & & & & 1 & 1 & & & & & & & & & & & & & & & & \\
\hline Schmidtocrinus & 14 & & & & & & & & & & & & & & & 1 & & & & & & & & & & & & & & & & \\
\hline Schultzicrinus & 13 & & & & & & & & & & & & & & 1 & & & & & & & & & & & & & & & & & \\
\hline Scoliocrinus & 14 & 15 & & & & & & & & & & & & & & 1 & 1 & & & & & & & & & & & & & & & \\
\hline Sigambrocrinus & 11 & 14 & & & & & & & & & & & 1 & 1 & 1 & 1 & & & & & & & & & & & & & & & & \\
\hline Situlacrinus & 13 & & & & & & & & & & & & & & 1 & & & & & & & & & & & & & & & & & \\
\hline Sphaerocrinus & 14 & 15 & & & & & & & & & & & & & & 1 & 1 & & & & & & & & & & & & & & & \\
\hline STEWBRECRINUS & 11 & & & & & & & & & & & & 1 & & & & & & & & & & & & & & & & & & & \\
\hline Streblocrinus & 15 & & & & & & & & & & & & & & & & 1 & & & & & & & & & & & & & & & \\
\hline Streptostomocrinus & 19 & 26 & & & & & & & & & & & & & & & & & & & 1 & 1 & 1 & 1 & 1 & 1 & 1 & 1 & & & & \\
\hline Sycocrinites & 19 & & & & & & & & & & & & & & & & & & & & 1 & & & & & & & & & & & \\
\hline Tenagocrinus & 26 & & & & & & & & & & & & & & & & & & & & & & & & & & & 1 & & & & \\
\hline Tetrapleurocrinus & 14 & & & & & & & & & & & & & & & 1 & & & & & & & & & & & & & & & & \\
\hline Thetidicrinus & 26 & & & & & & & & & & & & & & & & & & & & & & & & & & & 1 & & & & \\
\hline Treocrinus & 13 & & & & & & & & & & & & & & 1 & & & & & & & & & & & & & & & & & \\
\hline Vadarocrinus & 12 & & & & & & & & & & & & & 1 & & & & & & & & & & & & & & & & & & \\
\hline Vasocrinus & 11 & 15 & & & & & & & & & & & 1 & 1 & 1 & 1 & 1 & & & & & & & & & & & & & & & \\
\hline ZYGIOCRINUS & 18 & & & & & & & & & & & & & & & & & & & 1 & & & & & & & & & & & & \\
\hline Zygotocrinus & 18 & & & & & & & & & & & & & & & & & & & 1 & & & & & & & & & & & & \\
\hline & & & & & & & & & & & & & & & & & & & & & & & & & & & & & & & & \\
\hline $\begin{array}{c}\text { PRIMITIVE CLADID } \\
\text { TOTALS }\end{array}$ & & & 0 & 0 & 0 & 0 & 2 & 2 & 2 & 7 & 10 & 11 & 20 & 21 & 38 & 33 & 32 & 15 & 9 & 16 & 21 & 10 & 13 & 15 & 13 & 14 & 16 & 37 & \multicolumn{3}{|c|}{$\begin{array}{lll}4 & 3 & 0\end{array}$} & 0 \\
\hline & & & 1 & 2 & 3 & 4 & 5 & 6 & 7 & 8 & 9 & 10 & 11 & 12 & 13 & 14 & 15 & 16 & 17 & 18 & 19 & 20 & 21 & 22 & 23 & \begin{tabular}{|l|}
24 \\
\end{tabular} & 25 & $\mid 26$ & 27 & 28 & 29 & 30 \\
\hline & & & & & & & & & & & & & & & & & & & & & & & & & & & & & & & & \\
\hline \multicolumn{33}{|l|}{ ADVANCED CLADIDS } \\
\hline Aaglacrinus & 22 & 23 & & & & & & & & & & & & & & & & & & & & & & 1 & 1 & & & & & & & \\
\hline Aatocrinus & 22 & 24 & & & & & & & & & & & & & & & & & & & & & & 1 & 1 & 1 & & & & & & \\
\hline Abrotocrinus & 18 & 19 & & & & & & & & & & & & & & & & & & 1 & 1 & & & & & & & & & & & \\
\hline Acylocrinus & 18 & 19 & & & & & & & & & & & & & & & & & & 1 & 1 & & & & & & & & & & & \\
\hline Adacrinus & 22 & 23 & & & & & & & & & & & & & & & & & & & & & & 1 & 1 & & & & & & & \\
\hline ADIAKRITOCRINUS & 18 & & & & & & & & & & & & & & & & & & & 1 & & & & & & & & & & & & \\
\hline
\end{tabular}




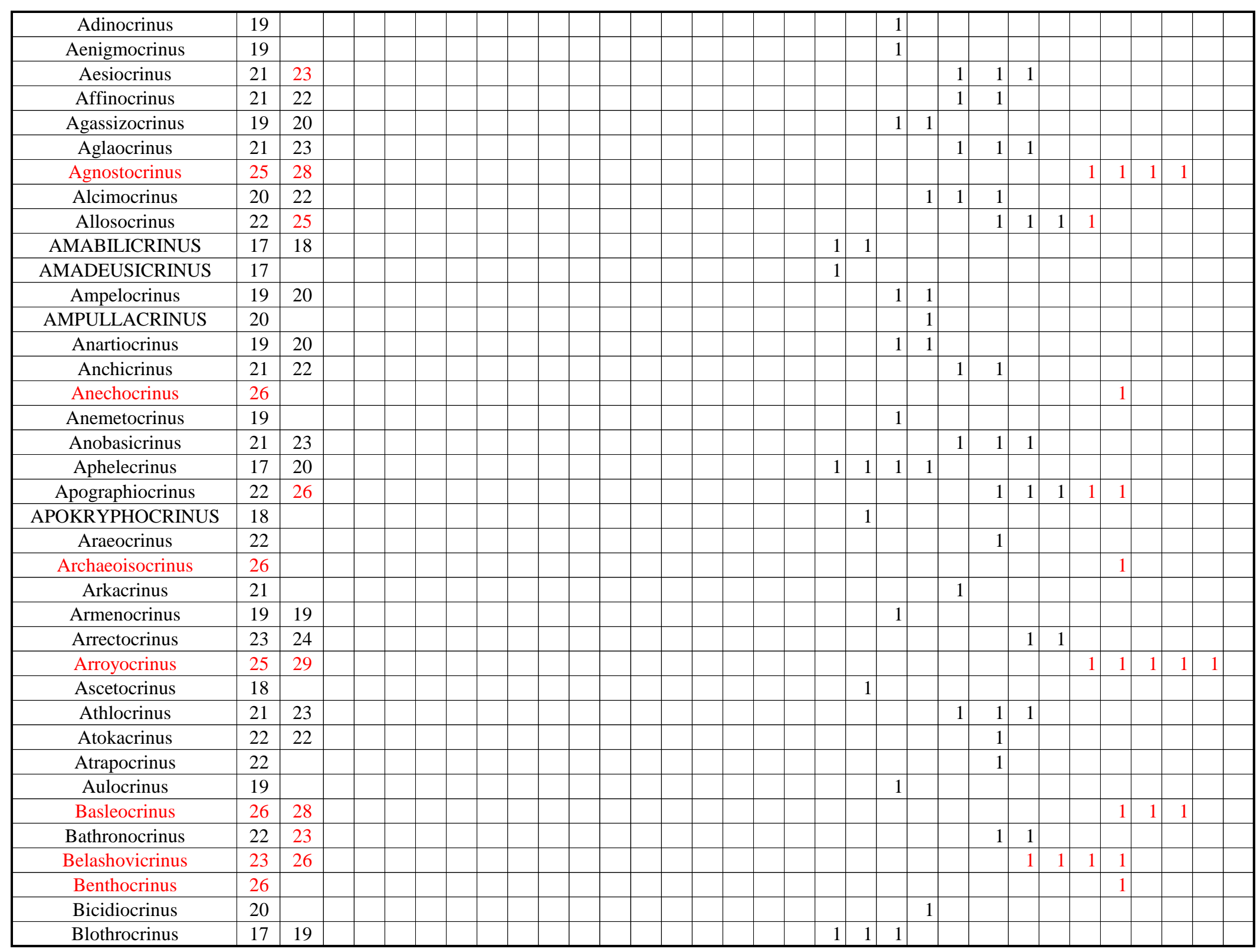




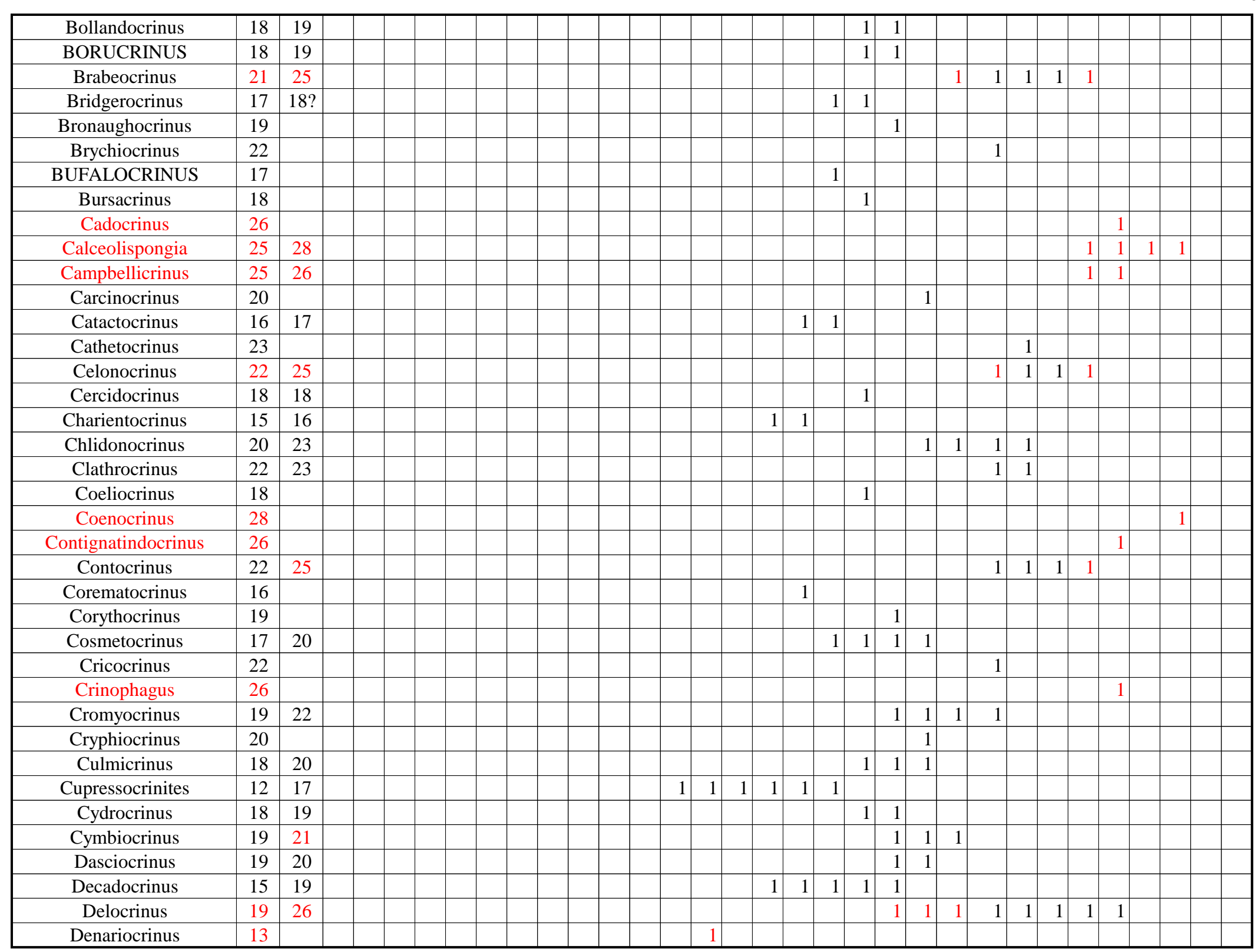




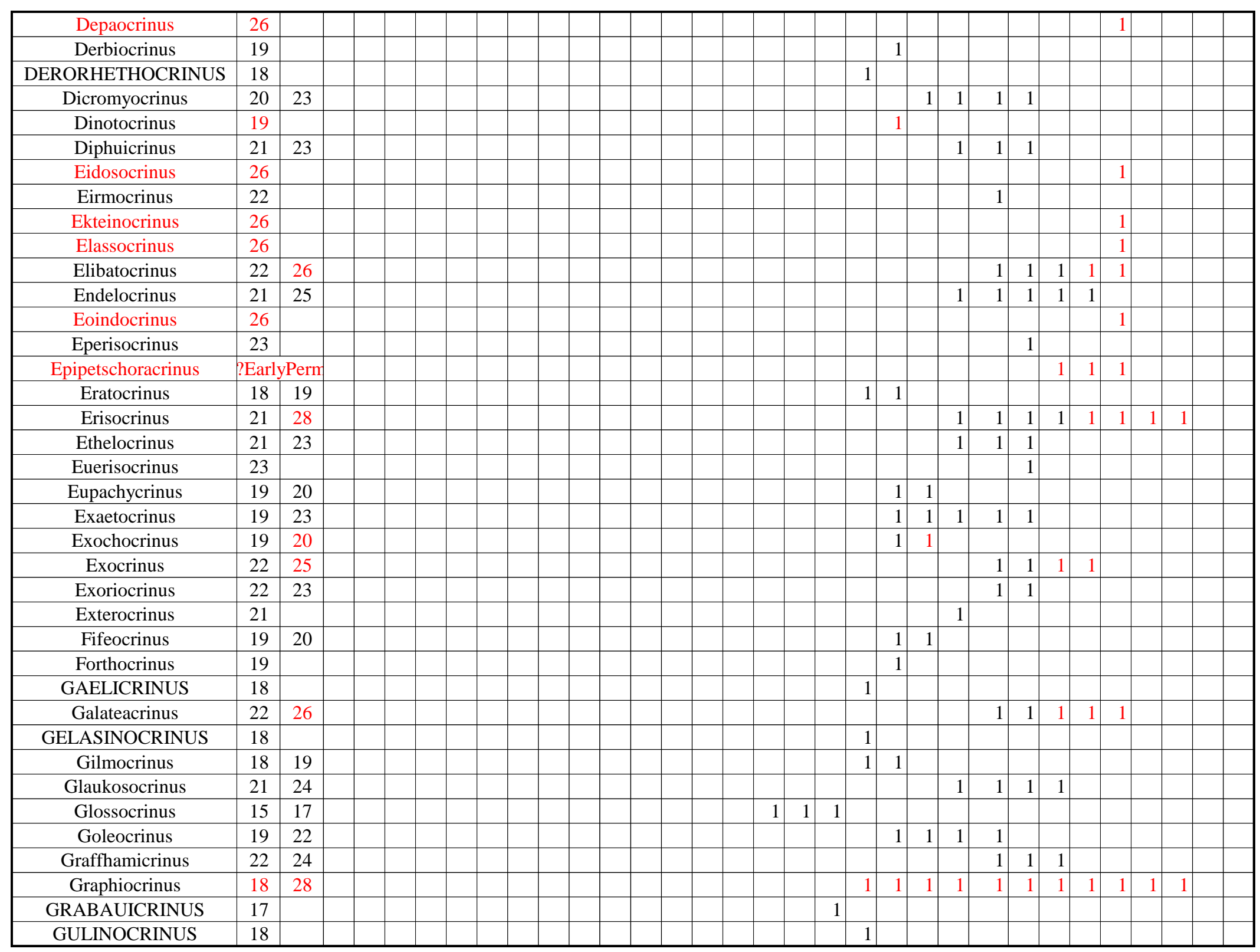




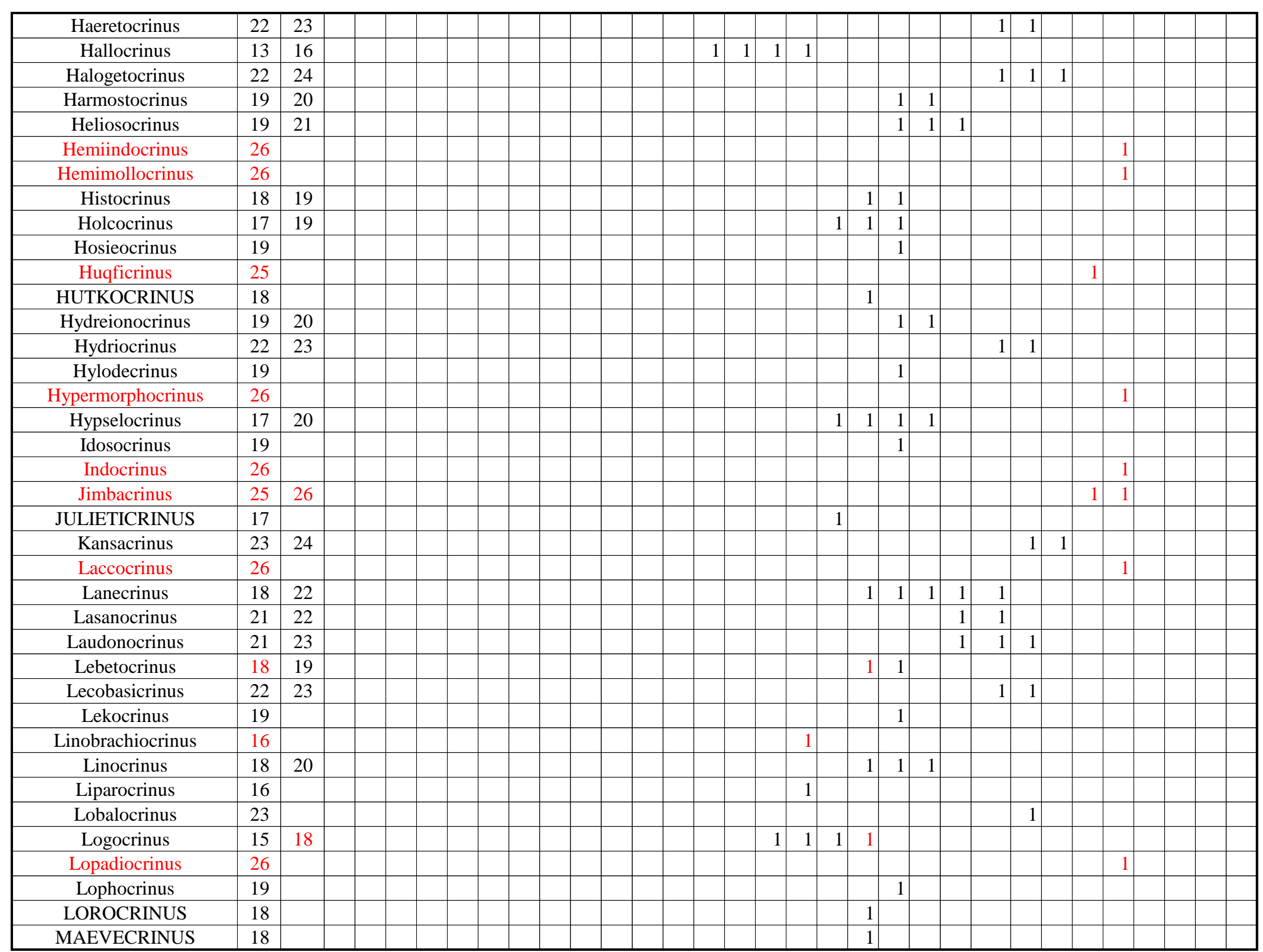




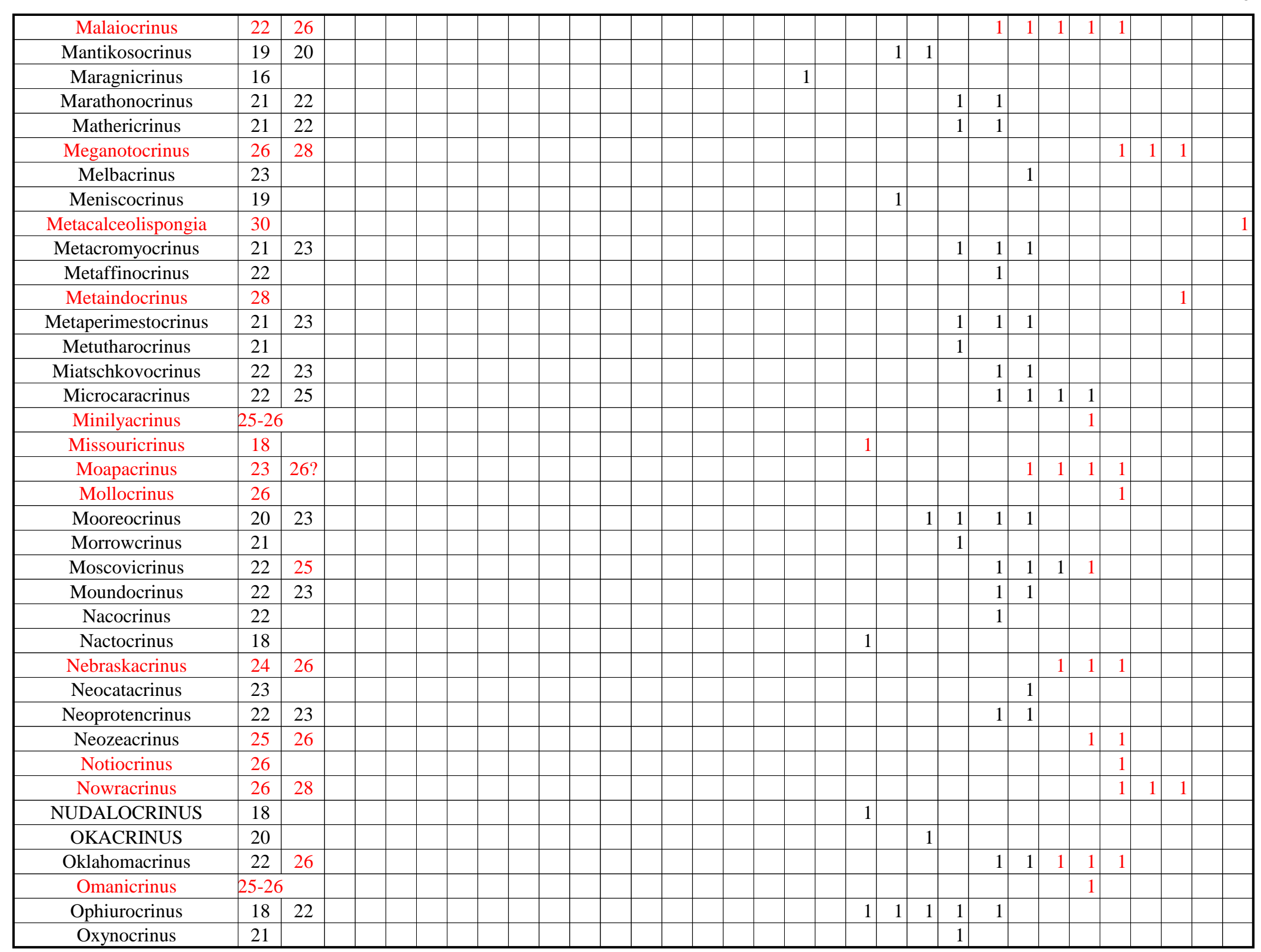




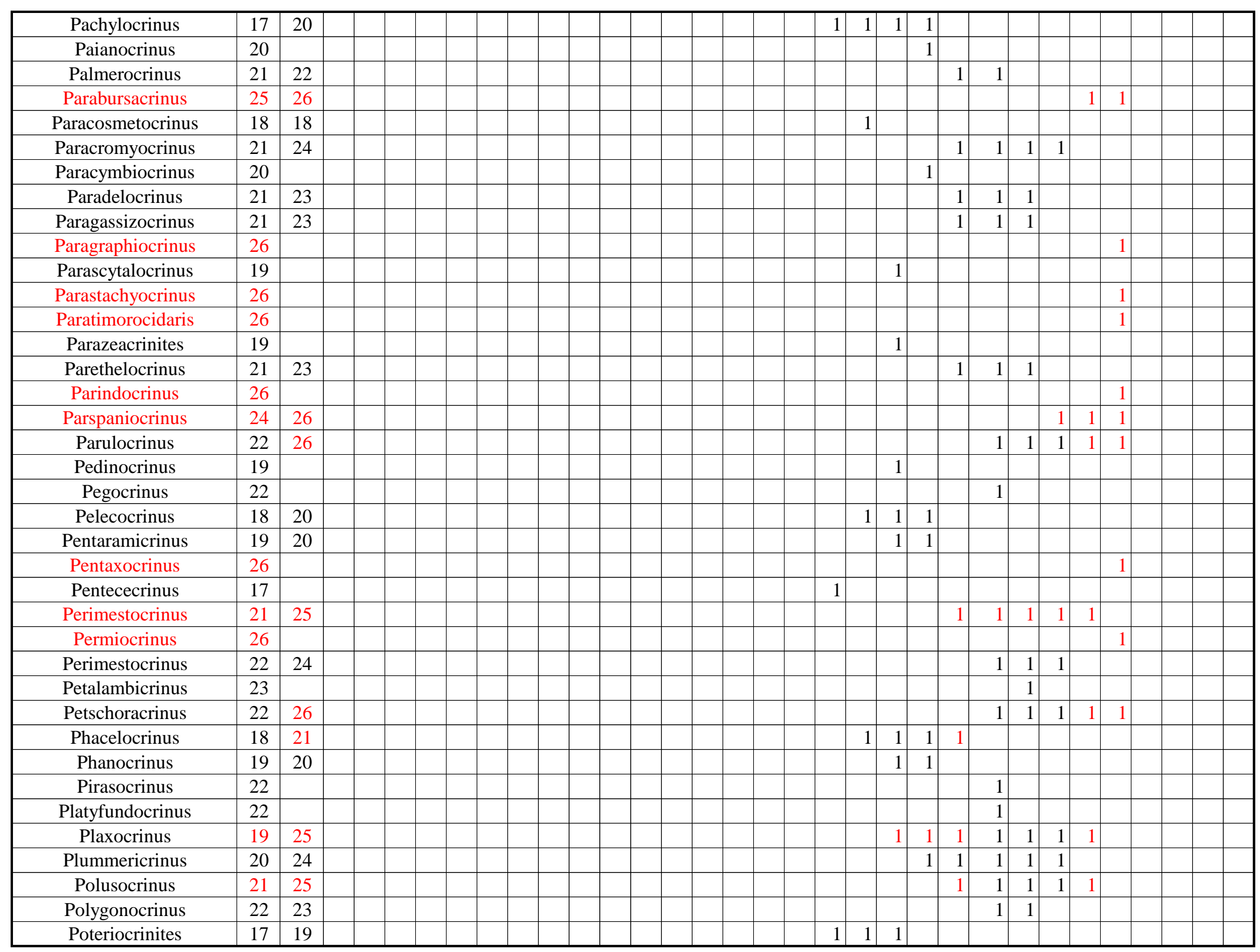




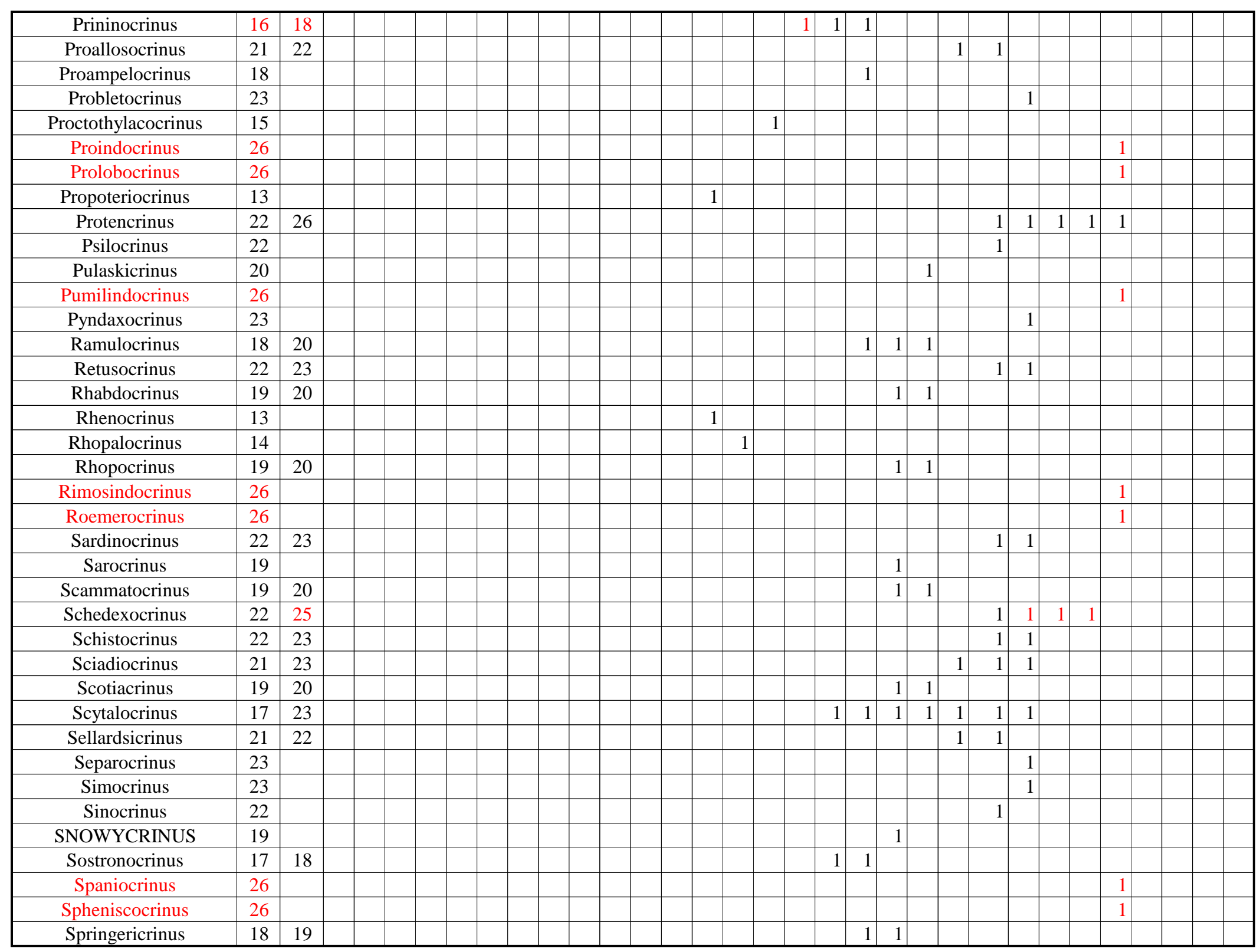




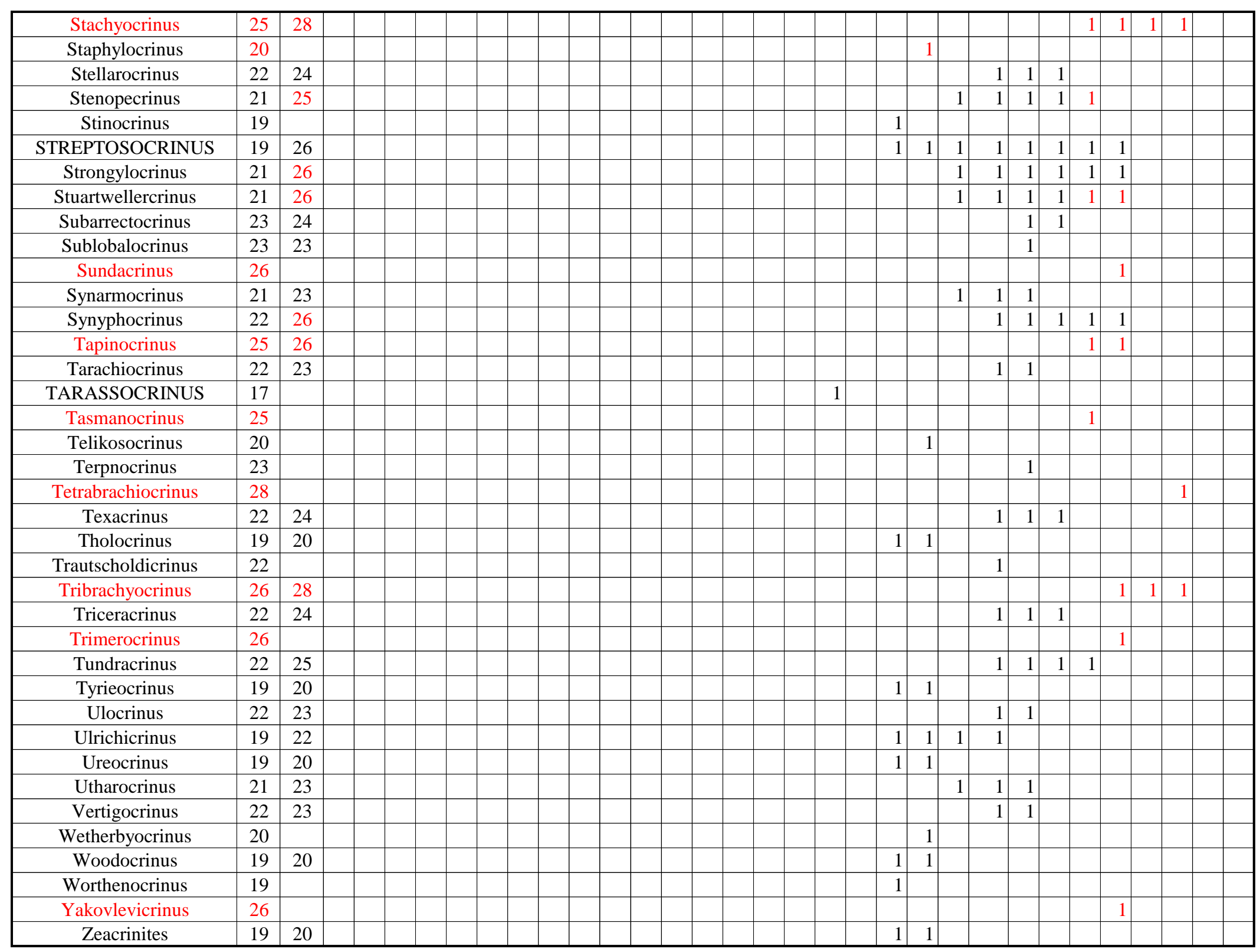




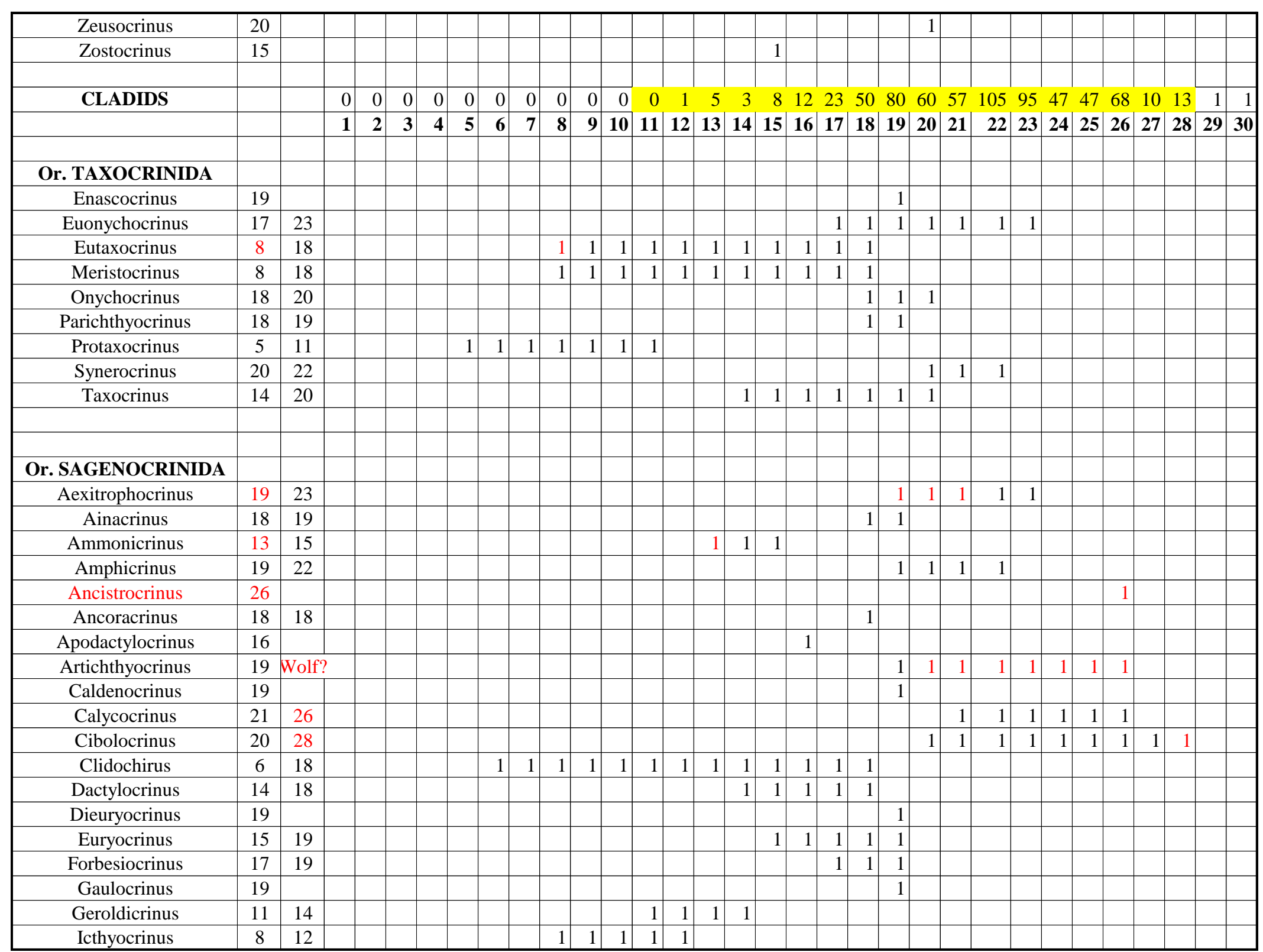




\begin{tabular}{|c|c|c|c|c|c|c|c|c|c|c|c|c|c|c|c|c|c|c|c|c|c|c|c|c|c|c|c|c|c|c|c|c|}
\hline Lecanocrinus & 7 & 13 & & & & & & & 1 & 1 & 1 & 1 & 1 & 1 & 1 & & & & & & & & & & & & & & & & & \\
\hline Lecocrinus & 8 & 19 & & & & & & & & 1 & 1 & 1 & 1 & 1 & 1 & 1 & 1 & 1 & 1 & 1 & 1 & & & & & & & & & & & \\
\hline Loxocrinus & 26 & & & & & & & & & & & & & & & & & & & & & & & & & & & 1 & & & & \\
\hline Mespilocrinus & 18 & 19 & & & & & & & & & & & & & & & & & & 1 & 1 & & & & & & & & & & & \\
\hline Metichthyocrinus & 18 & 19 & & & & & & & & & & & & & & & & & & 1 & 1 & & & & & & & & & & & \\
\hline Miracrinus & 11 & & & & & & & & & & & & 1 & & & & & & & & & & & & & & & & & & & \\
\hline Nevadacrinus & 25 & & & & & & & & & & & & & & & & & & & & & & & & & & 1 & & & & & \\
\hline Nipterocrinus & 18 & 19 & & & & & & & & & & & & & & & & & & 1 & 1 & & & & & & & & & & & \\
\hline Nummicrinus & 8 & 11 & & & & & & & & 1 & 1 & 1 & 1 & & & & & & & & & & & & & & & & & & & \\
\hline Palaeoholopus & 26 & & & & & & & & & & & & & & & & & & & & & & & & & & & 1 & & & & \\
\hline Pabianocrinus & 22 & 23 & & & & & & & & & & & & & & & & & & & & & & 1 & 1 & & & & & & & \\
\hline Paraclidochirus & 11 & 17 & & & & & & & & & & & 1 & 1 & 1 & 1 & 1 & 1 & 1 & & & & & & & & & & & & & \\
\hline Paramphicrinus & 21 & 23 & & & & & & & & & & & & & & & & & & & & & 1 & 1 & 1 & & & & & & & \\
\hline Permobrachypus & 26 & & & & & & & & & & & & & & & & & & & & & & & & & & & 1 & & & & \\
\hline Petrocrinus & 26 & & & & & & & & & & & & & & & & & & & & & & & & & & & 1 & & & & \\
\hline Plagiocrinus & 26 & & & & & & & & & & & & & & & & & & & & & & & & & & & 1 & & & & \\
\hline Proapsidocrinus & 26 & & & & & & & & & & & & & & & & & & & & & & & & & & & 1 & & & & \\
\hline Prophyllocrinus & 26 & & & & & & & & & & & & & & & & & & & & & & & & & & & 1 & & & & \\
\hline Rumphiocrinus & 26 & & & & & & & & & & & & & & & & & & & & & & & & & & & 1 & & & & \\
\hline Synaptocrinus & 15 & $16-17$ & & & & & & & & & & & & & & & 1 & 1 & & & & & & & & & & & & & & \\
\hline Syntomocrinus & 26 & & & & & & & & & & & & & & & & & & & & & & & & & & & 1 & & & & \\
\hline Tagenocrinus & 15 & & & & & & & & & & & & & & & & 1 & & & & & & & & & & & & & & & \\
\hline Trampidocrinus & 25 & & & & & & & & & & & & & & & & & & & & & & & & & & 1 & & & & & \\
\hline Trinalicrinus & 28 & & & & & & & & & & & & & & & & & & & & & & & & & & & & & 1 & & \\
\hline Wachsmuthicrinus & 16 & 19 & & & & & & & & & & & & & & & & 1 & 1 & 1 & 1 & & & & & & & & & & & \\
\hline Zenocrinus & 21 & & & & & & & & & & & & & & & & & & & & & & 1 & & & & & & & & & \\
\hline FLEXIBLE TOTALS & & & 0 & 0 & 0 & 0 & 1 & 2 & 3 & 8 & 8 & 8 & 11 & 8 & 8 & 9 & 11 & 11 & 11 & 17 & 19 & 8 & 9 & 9 & 7 & 3 & 5 & 13 & 1 & 2 & 0 & 0 \\
\hline & & & 1 & 2 & 3 & 4 & 5 & 6 & 7 & 8 & 9 & 10 & 11 & 12 & 13 & 14 & 15 & 16 & 17 & 18 & 19 & 20 & 21 & 22 & 23 & 24 & 25 & 26 & 27 & 28 & 29 & 30 \\
\hline
\end{tabular}

